\title{
Bioactive Diterpenes, Norditerpenes, and Sesquiterpenes from a Formosan Soft Coral Cespitularia sp.
}

\author{
You-Cheng Lin ${ }^{1}$, Chi-Chien Lin ${ }^{2} \mathbb{1}$, Yi-Chia Chu ${ }^{2}$, Chung-Wei Fu ${ }^{3}$ and Jyh-Horng Sheu ${ }^{1,3,4,5,6, *}$ \\ 1 Doctoral Degree Program in Marine Biotechnology, National Sun Yat-sen University, Kaohsiung 804, Taiwan; \\ d045620002@nsysu.edu.tw \\ 2 Institute of Biomedical Science, National Chung-Hsing University, Taichung 402, Taiwan; \\ lincc@dragon.nchu.edu.tw (C.-C.L.); girl770409@smail.nchu.edu.tw (Y.-C.C.) \\ 3 Department of Marine Biotechnology and Resources, National Sun Yat-sen University, Kaohsiung 804, \\ Taiwan; m095020006@nsysu.edu.tw \\ 4 Department of Medical Research, China Medical University Hospital, China Medical University, \\ Taichung 404, Taiwan \\ 5 Graduate Institute of Natural Products, Kaohsiung Medical University, Kaohsiung 807, Taiwan \\ 6 Frontier Center for Ocean Science and Technology, National Sun Yat-sen University, Kaohsiung 804, Taiwan \\ * Correspondence: sheu@mail.nsysu.edu.tw; Tel.: +886-7-5252-000 (ext. 5030)
}

Citation: Lin, Y.-C.; Lin, C.-C.; Chu, Y.-C.; Fu, C.-W.; Sheu, J.-H. Bioactive Diterpenes, Norditerpenes, and Sesquiterpenes from a Formosan Soft Coral Cespitularia sp.. Pharmaceuticals 2021, 14, 1252. https://doi.org/ $10.3390 /$ ph14121252

Academic Editor: Jean Jacques Vanden Eynde

Received: 28 September 2021 Accepted: 28 November 2021 Published: 1 December 2021

Publisher's Note: MDPI stays neutral with regard to jurisdictional claims in published maps and institutional affiliations.

Copyright: () 2021 by the authors. Licensee MDPI, Basel, Switzerland. This article is an open access article distributed under the terms and conditions of the Creative Commons Attribution (CC BY) license (https:// creativecommons.org/licenses/by/ $4.0 /)$.

\begin{abstract}
Chemical investigation of the soft coral Cespitularia sp. led to the discovery of twelve new verticillane-type diterpenes and norditerpenes: cespitulins $\mathrm{H}-\mathrm{O}(\mathbf{1}-\mathbf{8})$, one cyclic diterpenoidal amide cespitulactam L (9), norditerpenes cespitulin P (10), cespitulins $Q$ and R (11 and 12), four new sesquiterpenes: cespilins A-C (13-15) and cespitulolide (16), along with twelve known metabolites. The structures of these metabolites were established by extensive spectroscopic analyses, including 2D NMR experiments. Anti-inflammatory effects of the isolated compounds were studied by evaluating the suppression of pro-inflammatory protein tumor necrosis factor- $\alpha$ (TNF- $\alpha$ ) and nitric oxide (NO) overproduction, and the inhibition of the gene expression of inducible nitric oxide synthase (iNOS) and cyclooxygenase-2 (COX-2), in lipopolysaccharide-induced dendritic cells. A number of these metabolites were found to exhibit promising anti-inflammatory activities.
\end{abstract}

Keywords: verticillane; Cespitularia; anti-inflammatory activity

\section{Introduction}

In the inflammatory stimuli, the inflammatory mediators such as tumor necrosis factor- $\alpha$ (TNF- $\alpha)$, prostaglandin E2 (PGE2), and nitric oxide (NO) are known to be secreted through lipopolysaccharide (LPS)-induced activation of macrophages [1-3] and dendritic cells [4-7]. Furthermore, the overexpression of two inducible proteins, inducible nitric oxide synthase (iNOS) and cyclooxygenase-2 (COX-2) produced the excess amount of NO and PGE2 in the inflammatory process. It has been well known that natural products have a great potential in drug discovery, thus the anti-inflammatory activity screening by evaluating the suppression of TNF- $\alpha$ and NO overproduction, and the inhibition of iNOS and COX-2 protein and gene expression, in LPS-induced macrophages or dendritic cells (DCs) is one of the important methods for searching for anti-inflammatory agents from natural compounds [8-14].

Soft corals, in particular, those belonging to the genus Cespitularia (family Xeniidae), have afforded a series of verticillane-type diterpenes and some eudesmane-type sesquiterpenoids [15]. Secondary metabolites obtained from these soft corals have been shown to exhibit interesting biological activities, including cytotoxic [16-25], anti-inflammatory [25-27], antimicrobial [22], and antiviral [28] activities. Following the above findings, and with the aim of discovering bioactive compounds from marine invertebrates for further biomedical studies, we carried out the chemical investigation of the EtOAc extract of a Formosan soft coral Cespitularia sp. to search the bioactive principles, as preliminary bioassay showed that 
this crude extract exhibited significant activity to suppress the release of TNF- $\alpha$ and NO, and inhibited the upregulation of pro-inflammatory iNOS and COX-2 gene in lipopolysaccharide (LPS)-induced DCs. This study has led to the isolation of twenty-eight compounds, including eight new verticillane-type diterpenes cespitulins $\mathrm{H}-\mathrm{O}(\mathbf{1}-\mathbf{8})$, one new cyclic verticillane-type diterpenoidal amide cespitulactam $L(9)$, three new verticillane-type norditerpenes cespitulins $\mathrm{P}-\mathrm{R}(\mathbf{1 0} \mathbf{- 1 2})$, three new cadinane-type sesquiterpenes cespilins A-C (13-15), and one new eudesmane-type sesquiterpenoid cespitulolide (16) (Figure 1), along with twelve known compounds, cespitularin Q (17) [18,26], cespitularin E (18) [17], cespihypotin D (19) [29], cespihypotin F (20) [28], cespitularin O (21) [18], cespitularin D (22) $[17,20,21]$, cespitularin I (23) $[18,26]$, cespitularin F (24) $[17,20-22,26]$, atractylenolide III (25) [30-33], atractylenolide II (26) [31,33], atractylenolide V (27) [32], and 5-hydroxy3,4-dimethyl-5-pentylfuran-2(5H)-one (hydroxydihydrobovolide) (28) [34] (Figure 2). The structures of the compounds were elucidated on the basis of extensive spectroscopic analyses (IR, MS, 1D, and 2D NMR) and by comparison of the spectroscopic data with those of related known compounds.

Additionally, in order to discover bioactive substances for future medicinal application, the anti-inflammatory activities of the inhibition of TNF- $\alpha$ and NO, and the suppression of iNOS and COX-2 gene expression in LPS-induced DCs of the isolated compounds 1-28 were also evaluated and are reported herein.

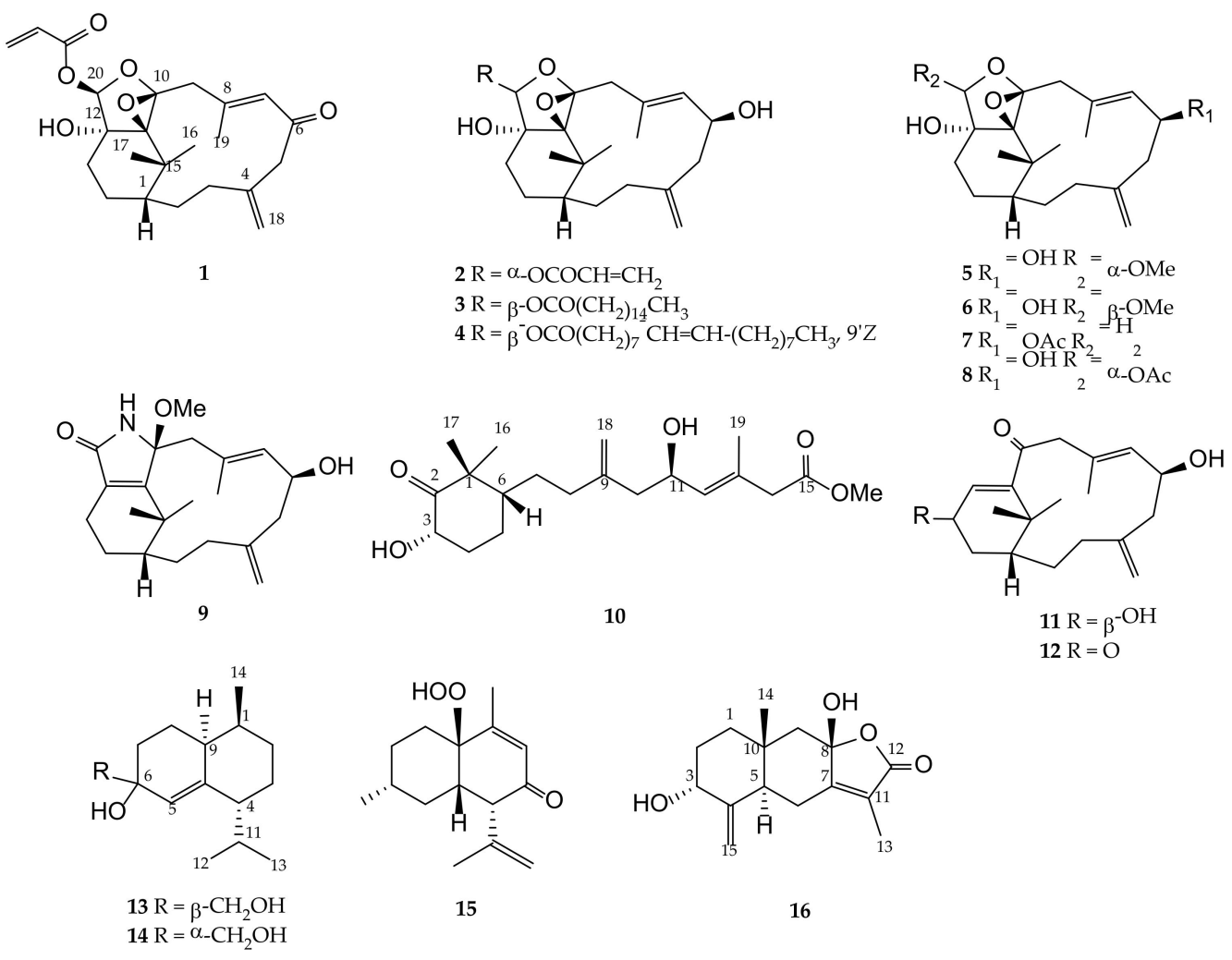

Figure 1. Structures of new compounds 1-16. 


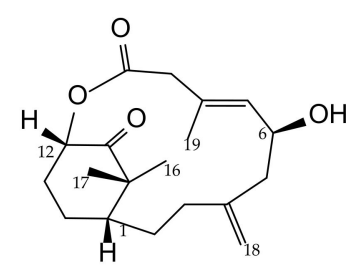

17

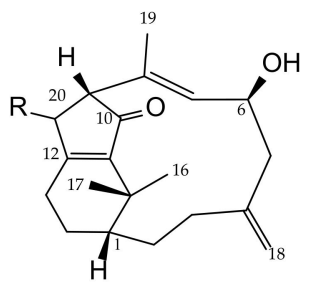

$23 \mathrm{R}=\mathrm{O}$

$24 \mathrm{R}=\alpha-\mathrm{OH}$

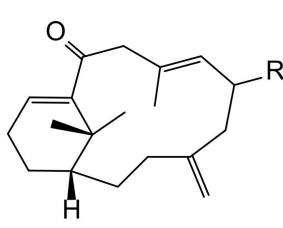

$18 \mathrm{R}=\beta-\mathrm{OH}$

$19 \mathrm{R}=\mathrm{O}$<smiles>[R][C@]12C[C@]3(C)CCCC(=C)[C@H]3CC1=C(C)C(=O)O2</smiles>

$25 \mathrm{R}=\mathrm{OH}$

$26 \mathrm{R}=\mathrm{H}$

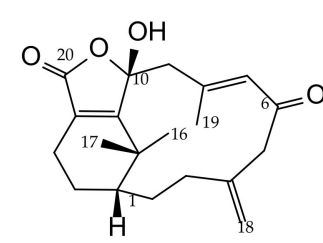

20<smiles>C=C1CCC[C@]2(C)[C@H](O)[C@]3(O)OC(=O)C(C)=C3C[C@H]12</smiles>

27

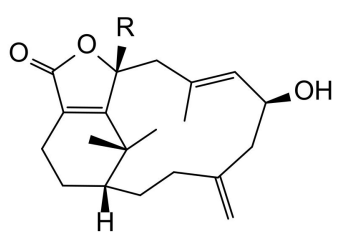

$21 \mathrm{R}=\mathrm{H}$

$22 \mathrm{R}=\mathrm{OH}$<smiles>CCCCCC1(O)C=C(C)C(=O)O1</smiles>

28

Figure 2. Structures of known compounds 17-28.

\section{Results}

\subsection{Structure Elucidation of the Verticillane-Type Diterpenes 1-9}

From the previously published reports [15-22,26-29], it was found that there is no unambiguous evidence for determining the absolute configuration of the verticillane-type compounds.

Cespitulin $\mathrm{H}(\mathbf{1})$ was isolated as a white amorphous powder and its molecular formula was established as $\mathrm{C}_{23} \mathrm{H}_{30} \mathrm{O}_{6}$ by HRESIMS $\left(\mathrm{m} / z 425.1932[\mathrm{M}+\mathrm{Na}]^{+}\right)$, accounting for nine degrees of unsaturation. The IR spectrum of 1 exhibited the absorption peaks of hydroxy $\left(3480 \mathrm{~cm}^{-1}\right)$ and carbonyl $\left(1741 \mathrm{~cm}^{-1}\right)$ groups. Assignment of two germinal methyls $\left(\delta_{\mathrm{C}} 26.8\right.$ and 24.9 , both $\mathrm{CH}_{3} ; \delta_{\mathrm{H}} 1.35$ and 0.72 , both s), a methyl $\left(\delta_{\mathrm{C}} 19.2, \mathrm{CH}_{3} ; \delta_{\mathrm{H}} 2.11\right.$, s), a vinyl group $\left(\delta_{\mathrm{C}} 132.6, \mathrm{CH}_{2}\right.$ and $127.6, \mathrm{CH} ; \delta_{\mathrm{H}} 6.15, \mathrm{brd}, J=17.5 \mathrm{~Hz}, 5.16, \mathrm{dd}, J=10.5,1.0 \mathrm{~Hz}$ and $5.77, \mathrm{dd}, J=17.5,10.5 \mathrm{~Hz})$, a 1,1 -disubstituted double bond $\left(\delta_{\mathrm{C}} 144.1, \mathrm{C}\right.$ and $116.5, \mathrm{CH}_{2} ; \delta_{\mathrm{H}}$ 5.09 and 4.77 , both s), a trisubstituted double bond $\left(\delta_{\mathrm{C}} 148.5, \mathrm{C}\right.$ and $\left.129.4, \mathrm{CH} ; \delta_{\mathrm{H}} 6.13, \mathrm{~s}\right)$, an acetal $\left(\delta_{\mathrm{C}} 101.8, \mathrm{CH} ; \delta_{\mathrm{H}} 5.96, \mathrm{~s}\right)$, three other $s p^{3}$ oxygenated carbons $\left(\delta_{\mathrm{C}} 94.6,80.0\right.$, and $72.8, C)$, a conjugated ester carbonyl $\left(\delta_{C} 164.9, C\right)$, and a conjugated ketone $\left(\delta_{C} 197.7, C\right)$ of verticillane-type diterpene were supported by analysis of the ${ }^{13} \mathrm{C}$ and ${ }^{1} \mathrm{H}$ NMR signals along with heteronuclear single quantum coherence (HSQC) spectrum (Tables 1 and 2).

Table 1. ${ }^{13} \mathrm{C}$ NMR spectroscopic data of compounds 1-6.

\begin{tabular}{|c|c|c|c|c|c|c|}
\hline No. & $1^{1}$ & $2^{2}$ & $3^{3}$ & $4^{3}$ & $5^{3}$ & $6^{3}$ \\
\hline 1 & $44.1, \mathrm{CH}^{4}$ & $44.0, \mathrm{CH}$ & $44.1, \mathrm{CH}$ & $44.1, \mathrm{CH}$ & $44.2, \mathrm{CH}$ & $44.2, \mathrm{CH}$ \\
\hline 2 & $34.4, \mathrm{CH}_{2}$ & $33.8, \mathrm{CH}_{2}$ & $33.8, \mathrm{CH}_{2}$ & $33.8, \mathrm{CH}_{2}$ & $34.0, \mathrm{CH}_{2}$ & $33.6, \mathrm{CH}_{2}$ \\
\hline 3 & $38.7, \mathrm{CH}_{2}$ & $37.7, \mathrm{CH}_{2}$ & 37.7, $\mathrm{CH}_{2}$ & 37.7, $\mathrm{CH}_{2}$ & $37.8, \mathrm{CH}_{2}$ & $37.8, \mathrm{CH}_{2}$ \\
\hline 4 & $144.1, \mathrm{C}$ & $145.7, \mathrm{C}$ & $145.7, \mathrm{C}$ & $145.7, \mathrm{C}$ & $145.8, \mathrm{C}$ & $145.7, \mathrm{C}$ \\
\hline 5 & $55.2, \mathrm{CH}_{2}$ & $45.8, \mathrm{CH}_{2}$ & $45.8, \mathrm{CH}_{2}$ & $47.5, \mathrm{CH}_{2}$ & $45.9, \mathrm{CH}_{2}$ & $45.6, \mathrm{CH}_{2}$ \\
\hline 6 & $197.7, \mathrm{C}$ & $69.2, \mathrm{CH}$ & $69.2, \mathrm{CH}$ & $69.2, \mathrm{CH}$ & $69.3, \mathrm{CH}$ & $69.1, \mathrm{CH}$ \\
\hline 7 & $129.4, \mathrm{CH}$ & $133.5, \mathrm{CH}$ & $133.5, \mathrm{CH}$ & $133.5, \mathrm{CH}$ & 133.3, CH & $133.2, \mathrm{CH}$ \\
\hline 8 & $148.5, \mathrm{C}$ & $132.4, \mathrm{C}$ & 132.0, C & $132.4, \mathrm{C}$ & $132.8, \mathrm{C}$ & $132.8, \mathrm{C}$ \\
\hline 9 & $41.0, \mathrm{CH}_{2}$ & $40.7, \mathrm{CH}_{2}$ & $40.7, \mathrm{CH}_{2}$ & $40.7, \mathrm{CH}_{2}$ & $41.0, \mathrm{CH}_{2}$ & $41.0, \mathrm{CH}_{2}$ \\
\hline 10 & $94.6, \mathrm{C}$ & $94.7, \mathrm{C}$ & $94.7, \mathrm{C}$ & $94.6, \mathrm{C}$ & $94.3, \mathrm{C}$ & $94.4, \mathrm{C}$ \\
\hline 11 & $72.8, \mathrm{C}$ & $72.4, \mathrm{C}$ & $72.4, \mathrm{C}$ & $72.4, \mathrm{C}$ & $72.8, \mathrm{C}$ & $72.9, \mathrm{C}$ \\
\hline 12 & $80.0, \mathrm{C}$ & $79.8, \mathrm{C}$ & 79.7, C & 79.7, C & 78.3, C & $79.9, \mathrm{C}$ \\
\hline 13 & $26.8, \mathrm{CH}_{2}$ & $26.2, \mathrm{CH}_{2}$ & $26.2, \mathrm{CH}_{2}$ & $26.2, \mathrm{CH}_{2}$ & 31.6, $\mathrm{CH}_{2}$ & $25.2, \mathrm{CH}_{2}$ \\
\hline 14 & $23.8, \mathrm{CH}_{2}$ & $25.4, \mathrm{CH}_{2}$ & $25.4, \mathrm{CH}_{2}$ & $25.4, \mathrm{CH}_{2}$ & $26.2, \mathrm{CH}_{2}$ & $25.5, \mathrm{CH}_{2}$ \\
\hline 15 & $38.1, C$ & $37.6, \mathrm{C}$ & $37.6, \mathrm{C}$ & $37.6, \mathrm{C}$ & $37.6, \mathrm{C}$ & $37.7, \mathrm{C}$ \\
\hline 16 & $24.9, \mathrm{CH}_{3}$ & $25.1, \mathrm{CH}_{3}$ & $25.2, \mathrm{CH}_{3}$ & $25.2, \mathrm{CH}_{3}$ & $25.1, \mathrm{CH}_{3}$ & $25.3, \mathrm{CH}_{3}$ \\
\hline
\end{tabular}


Table 1. Cont.

\begin{tabular}{|c|c|c|c|c|c|c|}
\hline No. & $1^{1}$ & $2^{2}$ & $3^{3}$ & $4^{3}$ & $5^{3}$ & $6^{3}$ \\
\hline 17 & $26.8, \mathrm{CH}_{3}$ & $26.4, \mathrm{CH}_{3}$ & $26.4, \mathrm{CH}_{3}$ & $26.4, \mathrm{CH}_{3}$ & 26.0, $\mathrm{CH}_{3}$ & $26.4, \mathrm{CH}_{3}$ \\
\hline 18 & $116.5, \mathrm{CH}_{2}$ & $115.8, \mathrm{CH}_{2}$ & $115.8, \mathrm{CH}_{2}$ & $115.8, \mathrm{CH}_{2}$ & $115.7, \mathrm{CH}_{2}$ & $115.7, \mathrm{CH}_{2}$ \\
\hline 19 & $19.2, \mathrm{CH}_{3}$ & $17.2, \mathrm{CH}_{3}$ & $17.4, \mathrm{CH}_{3}$ & $17.2, \mathrm{CH}_{3}$ & $17.4, \mathrm{CH}_{3}$ & $17.4, \mathrm{CH}_{3}$ \\
\hline 20 & $101.8, \mathrm{CH}$ & 101.3, $\mathrm{CH}$ & $100.8, \mathrm{CH}$ & $100.8, \mathrm{CH}$ & $104.6, \mathrm{CH}$ & 109.1, CH \\
\hline 21 & $164.9, \mathrm{C}$ & $164.8, \mathrm{C}$ & & & $56.6, \mathrm{CH}_{3}$ & $57.5, \mathrm{CH}_{3}$ \\
\hline 22 & $127.6, \mathrm{CH}$ & 127.3, $\mathrm{CH}$ & & & & \\
\hline 23 & $132.6, \mathrm{CH}_{2}$ & $132.7, \mathrm{CH}_{2}$ & & & & \\
\hline $1^{\prime}$ & & & $172.8, \mathrm{C}$ & $172.8, \mathrm{C}$ & & \\
\hline $2^{\prime}$ & & & $34.1, \mathrm{CH}_{2}$ & $34.1, \mathrm{CH}_{2}$ & & \\
\hline $3^{\prime}$ & & & 24.7, $\mathrm{CH}_{2}$ & 24.7, $\mathrm{CH}_{2}$ & & \\
\hline $4^{\prime}-13^{\prime}$ & & & $\begin{array}{c}29.7 \times 2,29.6 \times 3,29.4 \times \\
3,29.2,29.0, \text { each } \mathrm{CH}_{2}\end{array}$ & & & \\
\hline $4^{\prime}-7^{\prime} / 12^{\prime}-15^{\prime}$ & & & & $\begin{array}{l}29.8,29.7,29.5,29.3 \times 2, \\
29.2 \times 2,29.0 \text { each } \mathrm{CH}_{2}\end{array}$ & & \\
\hline $8^{\prime} / 11^{\prime}$ & & & & $27.2 / 27.1$, each $\mathrm{CH}_{2}$ & & \\
\hline $9^{\prime}-10^{\prime}$ & & & & 130.1/129.7, each CH & & \\
\hline $14^{\prime}$ & & & $31.9, \mathrm{CH}_{2}$ & & & \\
\hline $15^{\prime}$ & & & $22.7, \mathrm{CH}_{2}$ & & & \\
\hline $16^{\prime}$ & & & $14.1, \mathrm{CH}_{3}$ & $31.9, \mathrm{CH}_{2}$ & & \\
\hline $17^{\prime}$ & & & & $22.7, \mathrm{CH}_{2}$ & & \\
\hline $18^{\prime}$ & & & & $14.1, \mathrm{CH}_{3}$ & & \\
\hline
\end{tabular}

${ }^{1}$ Spectrum recorded at $500 \mathrm{MHz}$ in benzene- $d_{6} \cdot{ }^{2}$ Spectrum recorded at $400 \mathrm{MHz}$ in $\mathrm{CDCl}_{3} \cdot{ }^{3}$ Spectrum recorded at $500 \mathrm{MHz}$ in $\mathrm{CDCl}_{3} \cdot{ }^{4}$ Multiplicities deduced by the HSQC experiment.

Table 2. ${ }^{1} \mathrm{H}$ NMR spectroscopic data of compounds $\mathbf{1 - 5}$.

\begin{tabular}{|c|c|c|c|c|c|}
\hline No. & $1^{1}$ & $2^{2}$ & $3^{3}$ & $4^{3}$ & $5^{3}$ \\
\hline 1 & $1.19, \mathrm{~m}$ & $1.48, \mathrm{~m}$ & $1.49, \mathrm{~m}$ & $1.49, \mathrm{~m}$ & $1.46, \mathrm{~m}$ \\
\hline \multirow[t]{2}{*}{2} & $1.66, \mathrm{~m}$ & $1.82, \mathrm{~m}$ & $1.81, \mathrm{~m}$ & $1.81, \mathrm{~m}$ & $1.84, \mathrm{~m}$ \\
\hline & $1.38, \mathrm{~m}$ & $1.11, \mathrm{td}(14.0,5.0)$ & $1.11, \operatorname{td}(14.5,5.0)$ & $1.11, \mathrm{td}(14.0,5.5)$ & $1.09, \operatorname{td}(14.5,4.5)$ \\
\hline \multirow[t]{2}{*}{3} & $1.94, \operatorname{td}(13.0,4.0)^{4}$ & $2.22, \mathrm{~m}$ & $2.22 \mathrm{~m}$ & $2.22, \mathrm{~m}$ & $2.20, \mathrm{td}(14.0,4.5)$ \\
\hline & $1.82, \operatorname{td}(13.0,4.0)$ & $2.08, \operatorname{td}(14.0,3.2)$ & $2.08, \operatorname{td}(14.0,4.0)$ & $2.08, \mathrm{~m}$ & $2.08, \mathrm{dd}(14.0,4.5)$ \\
\hline \multirow[t]{2}{*}{5} & $2.94, \mathrm{~d}(11.0)$ & $2.65, \mathrm{dd}(12.5,3.2)$ & 2.66, dd $(13.0,3.0)$ & $2.66, \mathrm{dd}(12.5,2.5)$ & $2.65, \mathrm{dd}(13.0,3.0)$ \\
\hline & $2.85, \mathrm{~d}(11.0)$ & $2.24, \mathrm{~m}$ & $2.25, \mathrm{~m}$ & $2.25, \mathrm{~m}$ & $2.22, \mathrm{~m}$ \\
\hline 6 & & $4.49, \mathrm{t}(8.0)$ & 4.50 , quint (3.0) & $4.50, \mathrm{~m}$ & 4.50, br t $(8.5)$ \\
\hline 7 & $6.13, \mathrm{~s}$ & $5.47, \mathrm{~d}(8.0)$ & $5.47, \mathrm{~d}(8.5)$ & $5.47, \mathrm{~d}(8.0)$ & $5.46, \mathrm{~d}(8.0)$ \\
\hline \multirow[t]{2}{*}{9} & $3.00, \mathrm{~d}(16.0)$ & $3.10, \mathrm{~d}(14.4)$ & $3.09, \mathrm{~d}(14.5)$ & $3.09, \mathrm{~d}(14.0)$ & $3.03, \mathrm{~d}(14.5)$ \\
\hline & $2.21, \mathrm{~d}(16.0)$ & $2.55, \mathrm{~d}(14.4)$ & $2.54, \mathrm{~d}(14.5)$ & $2.54, \mathrm{~d}(14.0)$ & $2.52, \mathrm{~d}(14.5)$ \\
\hline \multirow[t]{2}{*}{13} & $1.57, \operatorname{td}(14.0,3.5)$ & $1.71, \mathrm{td}(14.0,3.6)$ & $1.67, \mathrm{~m}$ & $1.66, \mathrm{~m}$ & 1.70, br d $(14.0)$ \\
\hline & $1.46, \mathrm{~m}$ & $1.58, \mathrm{~m}$ & $1.50, \mathrm{~m}$ & $1.50, \mathrm{~m}$ & $1.58, \mathrm{~m}$ \\
\hline \multirow[t]{2}{*}{14} & $2.16, \mathrm{~m}$ & $2.28, \mathrm{~m}$ & $2.28, \mathrm{~m}$ & $2.27, \mathrm{~m}$ & $2.31, \mathrm{tt}(17.5,3.5)$ \\
\hline & $\begin{array}{l}\text { 1.11, ddd }(14.0,6.0 \\
3.5)\end{array}$ & $1.37, \mathrm{~m}$ & $1.37, \mathrm{~m}$ & $1.37, \mathrm{~m}$ & $1.33, \mathrm{~m}$ \\
\hline 16 & $0.72,3 \mathrm{H}, \mathrm{s}$ & $0.94,3 \mathrm{H}, \mathrm{s}$ & $0.98,3 \mathrm{H}, \mathrm{s}$ & $0.98,3 \mathrm{H}, \mathrm{s}$ & $0.95,3 \mathrm{H}, \mathrm{s}$ \\
\hline 17 & $1.35,3 \mathrm{H}, \mathrm{s}$ & $1.34,3 \mathrm{H}, \mathrm{s}$ & $1.33,3 \mathrm{H}, \mathrm{s}$ & $1.33,3 \mathrm{H}, \mathrm{s}$ & $1.31,3 \mathrm{H}, \mathrm{s}$ \\
\hline 18 & $5.09,4.77$, both s & $4.93,2 \mathrm{H}, \mathrm{s}$ & $4.94,2 \mathrm{H}, \mathrm{s}$ & $4.94,2 \mathrm{H}, \mathrm{s}$ & $4.93,2 \mathrm{H}, \mathrm{s}$ \\
\hline 19 & $2.11,3 \mathrm{H}, \mathrm{s}$ & $1.81,3 \mathrm{H}, \mathrm{s}$ & $1.81,3 \mathrm{H}, \mathrm{s}$ & $1.81,3 \mathrm{H}, \mathrm{s}$ & $1.83,3 \mathrm{H}, \mathrm{s}$ \\
\hline 20 & $5.96, \mathrm{~s}$ & $5.70, \mathrm{~s}$ & $5.63, \mathrm{~s}$ & $5.63, \mathrm{~s}$ & $4.36, \mathrm{~s}$ \\
\hline 21 & & & & & $3.47,3 \mathrm{H}, \mathrm{s}$ \\
\hline 22 & $5.77, \mathrm{dd}(17.5,10.5)$ & $6.14, \mathrm{dd}(17.2,10.4)$ & & & \\
\hline \multirow[t]{2}{*}{23} & 6.15, br d (17.5) & $6.47, \mathrm{~d}(17.2)$ & & & \\
\hline & 5.16, dd $(10.5,1.0)$ & $5.94, \mathrm{~d}(10.4)$ & & & \\
\hline $2^{\prime}$ & & & $2.36, \mathrm{t}(7.5)$ & $2.36, \mathrm{t}(7.5)$ & \\
\hline $3^{\prime}$ & & & $1.62,2 \mathrm{H}, \mathrm{m}$ & $1.63,2 \mathrm{H}, \mathrm{m}$ & \\
\hline $4^{\prime}-15^{\prime}$ & & & $1.20-1.31,20 \mathrm{H}, \mathrm{m}$ & & \\
\hline $4^{\prime}-7^{\prime} / 12^{\prime}-17^{\prime}$ & & & & $1.25-1.34,20 \mathrm{H}, \mathrm{m}$ & \\
\hline
\end{tabular}


Table 2. Cont.

\begin{tabular}{|c|c|c|c|c|c|}
\hline No. & $1^{1}$ & $2^{2}$ & $3^{3}$ & $4^{3}$ & $5^{3}$ \\
\hline $8^{\prime} / 11^{\prime}$ & & & & $2.01, \mathrm{H}, \mathrm{m}$ & \\
\hline $9^{\prime} / 10^{\prime}$ & & & & $5.34, \mathrm{dd}(10.5,6.5)$ & \\
\hline $16^{\prime}$ & & & $0.88,3 \mathrm{H}, \mathrm{t}(7.0)$ & & \\
\hline $18^{\prime}$ & & & & $0.88,3 \mathrm{H}, \mathrm{t}(7.0)$ & \\
\hline $12-\mathrm{OH}$ & $2.25, \mathrm{br} \mathrm{s}$ & $2.64, \mathrm{br} \mathrm{s}$ & $2.52, \mathrm{br} \mathrm{s}$ & $2.53, \mathrm{br} \mathrm{s}$ & $3.29, \mathrm{br} \mathrm{s}$ \\
\hline
\end{tabular}

${ }^{1}$ Spectrum recorded at $500 \mathrm{MHz}$ in benzene- $d_{6} .{ }^{2}$ Spectrum recorded at $400 \mathrm{MHz}$ in $\mathrm{CDCl}_{3} .{ }^{3}$ Spectrum recorded at $500 \mathrm{MHz}_{\text {in }} \mathrm{CDCl}_{3} .{ }^{4} \mathrm{~J}$ values are in $\mathrm{Hz}$.

The planar structure of $\mathbf{1}$ was further determined by analysis of correlations spectroscopy (COSY) and heteronuclear multiple bond correlation (HMBC) correlations (Figure 3). The HMBC correlations of $\mathrm{H}_{2}-9\left(\delta_{\mathrm{H}} 3.00\right.$ and 2.21 , both $\left.\mathrm{d}, J=16.0 \mathrm{~Hz}\right)$ to $\mathrm{C}-10\left(\delta_{\mathrm{C}} 94.6, \mathrm{C}\right)$ and $\mathrm{C}-11\left(\delta_{\mathrm{C}} 72.8, \mathrm{C}\right)$, assigned a possible 10,11-tetrasubstituted epoxide moiety. Additionally, $\mathrm{HMBC}$ correlations of a hydroxy proton $\left(\delta_{\mathrm{H}} 2.25\right.$, br s) to both $\mathrm{C}-12\left(\delta_{\mathrm{C}} 80.0, \mathrm{C}\right)$ and $\mathrm{C}-13\left(\delta_{\mathrm{C}} 26.8, \mathrm{CH}_{2}\right)$, as well as an acetal proton $\mathrm{H}-20\left(\delta_{\mathrm{H}} 5.96, \mathrm{~s}\right)$ to both $\mathrm{C}-12$ and ester carbonyl carbon $\left(\delta_{\mathrm{C}} 164.9, \mathrm{C}, \mathrm{C}-21\right)$, positioned a hydroxy group at C-12 and an acrylate group at $\mathrm{C}-20$. The above findings and the remaining one degree of unsaturation were used to establish a polyoxygenated epoxytetrahydrofuran ring, as shown in formula of $\mathbf{1}$.
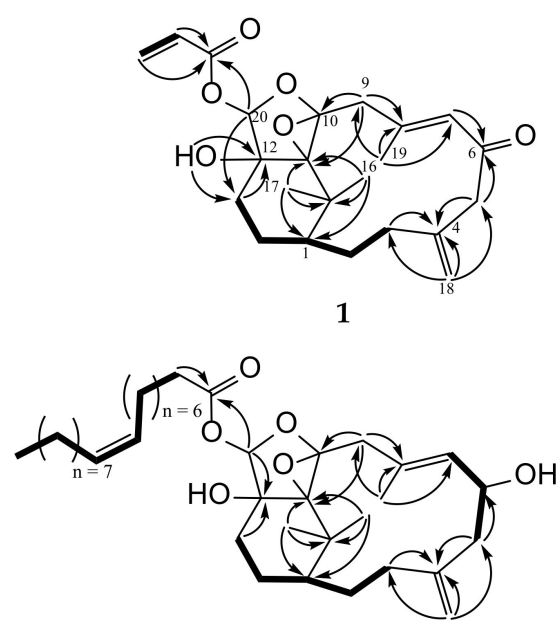

4
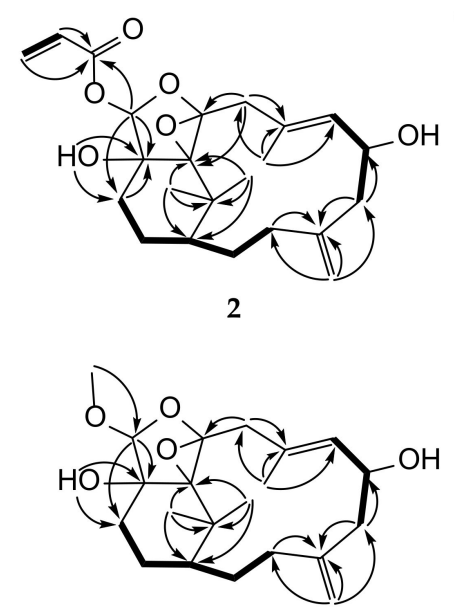

5 and 6
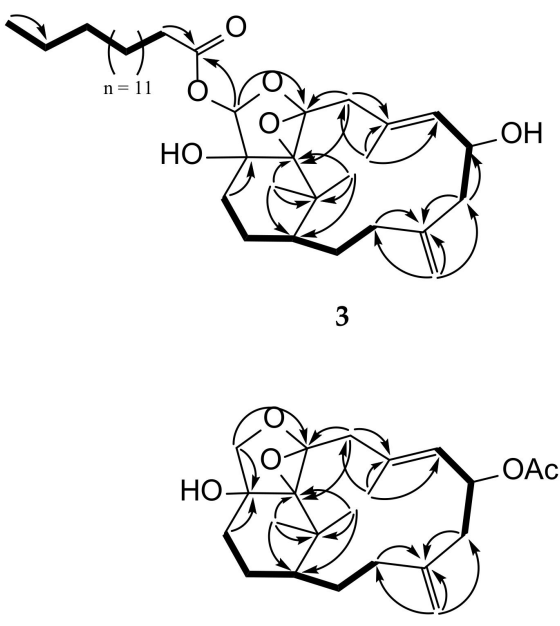

7
COSY

HMBC

Figure 3. Selected COSY and HMBC correlations of 1-7.

The relative stereochemistry of $\mathbf{1}$ was determined by the analysis of nuclear Overhauser effect spectroscopy (NOESY) correlations and molecular modeling from energyminimized (MM2) force field calculation. Assuming the $\beta$-orientation of $\mathrm{H}-1\left(\delta_{\mathrm{H}} 1.19, \mathrm{~m}\right)$, the NOE correlations of $\mathrm{H}-1$ with both $\mathrm{H}_{3}-16\left(\delta_{\mathrm{H}} 0.72\right.$, s) and $\mathrm{H}_{3}-17\left(\delta_{\mathrm{H}} 1.35, \mathrm{~s}\right)$ indicted the upward orientation of both $\mathrm{H}_{3}-16$ and $\mathrm{H}_{3}-17$. One proton of $\mathrm{H}_{2}-14\left(\delta_{\mathrm{H}} 2.16, \mathrm{~m}\right)$ exhibited NOE correlations with one proton of $\mathrm{H}_{2}-13\left(\delta_{\mathrm{H}} 1.46, \mathrm{~m}\right)$ and $\mathrm{H}_{3}-17$; thus the above methylene protons were characterized as $\mathrm{H}-14 \beta$ and $\mathrm{H}-13 \beta$, while the rest protons were assigned as $\mathrm{H}-14 \alpha\left(\delta_{\mathrm{H}} 1.11\right.$, ddd, $\left.J=14.0,6.0,3.5 \mathrm{~Hz}\right)$ and $\mathrm{H}-13 \alpha\left(\delta_{\mathrm{H}} 1.57, \mathrm{td}, J=14.0,3.5 \mathrm{~Hz}\right)$. Subsequently, $\mathrm{H}-20\left(\delta_{\mathrm{H}} 5.96, \mathrm{~s}\right)$ exhibited NOE interactions with both $\mathrm{H}-13 \alpha$ and $12-\mathrm{OH}$ $\left(\delta_{\mathrm{H}} 2.25, \mathrm{br} \mathrm{s}\right)$, revealing that $\mathrm{H}-20$ and the 12-hydroxy group were positioned on the $\alpha$ face. Moreover, $\mathrm{H}-7\left(\delta_{\mathrm{H}} 6.13, \mathrm{br}\right.$ s) exhibited an NOE response with one proton of $\mathrm{H}-9\left(\delta_{\mathrm{H}} 2.21, \mathrm{~d}\right.$, $J=16.0 \mathrm{~Hz})$, while $\mathrm{H}_{3}-19\left(\delta_{\mathrm{H}} 2.11, \mathrm{~s}\right)$ showed an NOE interaction with the other proton of $\mathrm{H}-9\left(\delta_{\mathrm{H}} 3.00, \mathrm{~d}, J=16.0 \mathrm{~Hz}\right)$ but not with $\mathrm{H}-7$, confirming the $E$ geometry of trisubstituted double bond at C-7/C-8. The above NOE results were shown to be well matched with a molecular model of minimized energy generated from MM2 calculation in Figure 4. Additionally, conformational searching of compound $\mathbf{1}$ by molecular mechanics model 
with MMFF force field calculation in the Spartan'14 program [35] was further performed. In a relative energy window of $0-3 \mathrm{Kcal} / \mathrm{mol}$, the results of the calculation displayed nine lowest energy conformers for $\mathbf{1}$ (Table S2 and Figure S113) which were shown to fit from the observed NOE correlations. From the above findings, the relative configuration of 1 was elucidated as that for formula 1.
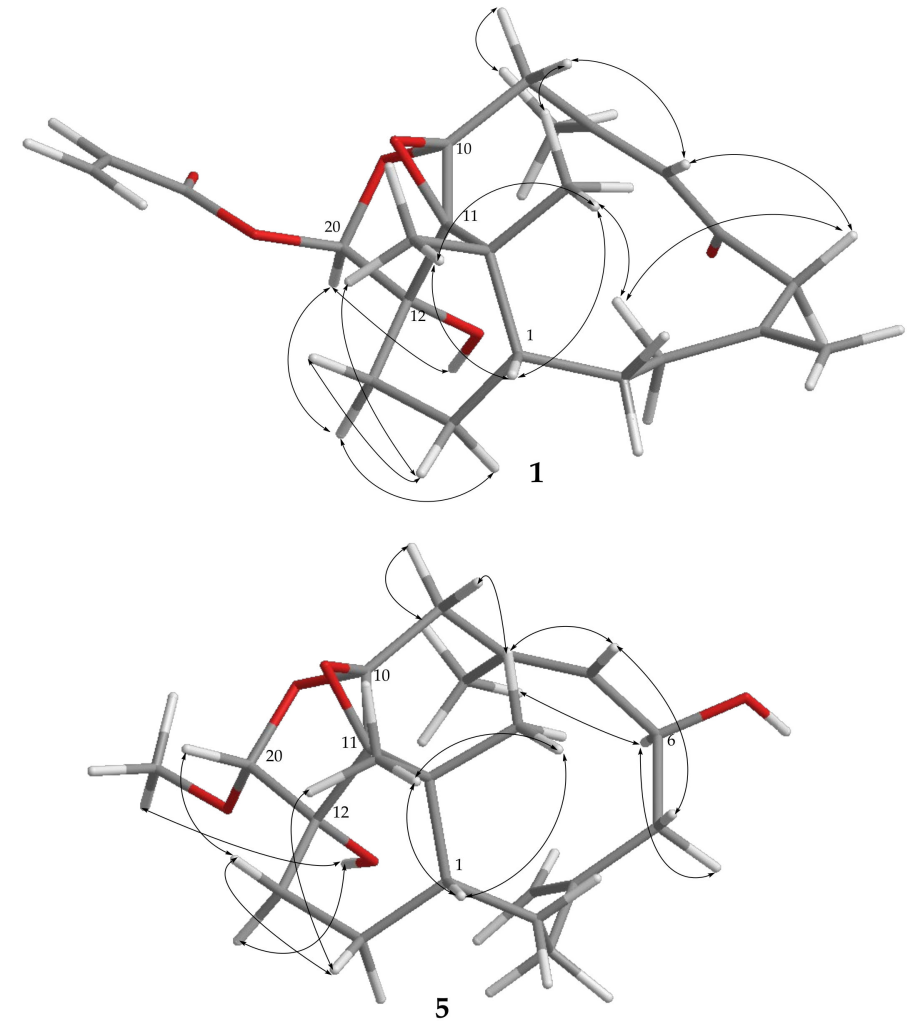
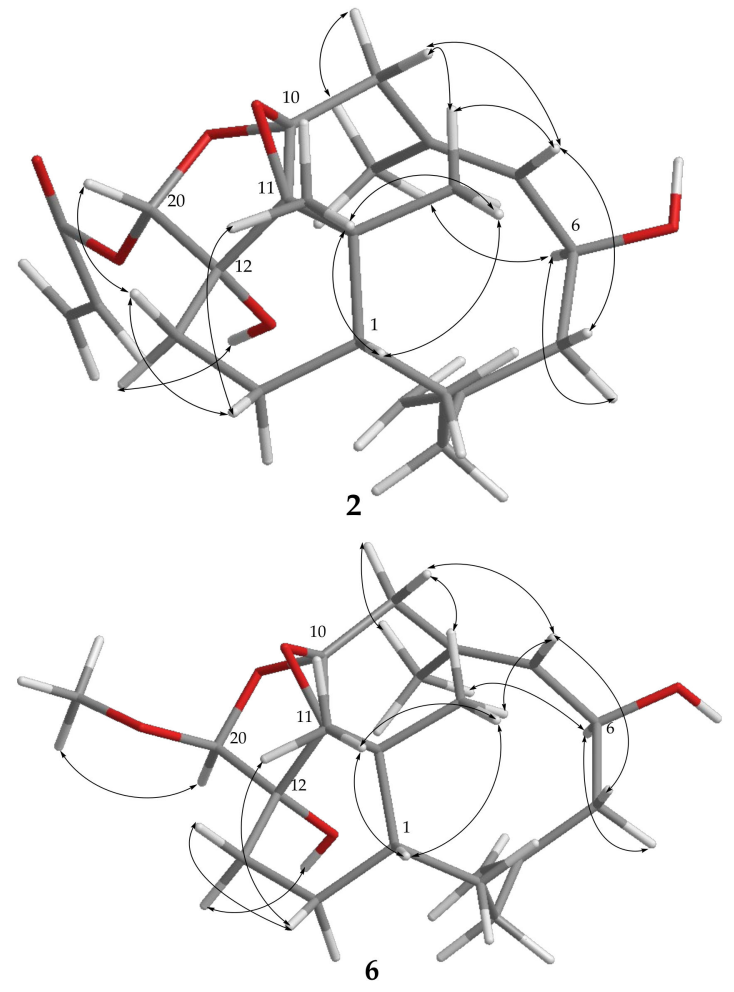

Figure 4. Selected NOE correlations of compounds 1, 2, 5, and 6.

Cespitulin I (2) appeared as a white amorphous powder with the molecular formula $\mathrm{C}_{23} \mathrm{H}_{32} \mathrm{O}_{6}$ as indicated by the HRESIMS $\left(\mathrm{m} / z 427.2089[\mathrm{M}+\mathrm{Na}]^{+}\right)$spectrum, suggesting the presence of eight degrees of unsaturation. The IR spectrum showed the absorptions of hydroxy $\left(3440 \mathrm{~cm}^{-1}\right)$ and carbonyl $\left(1740 \mathrm{~cm}^{-1}\right)$ groups. The NMR data of 2 (Tables 1 and 2) revealed this compound to be a tricyclic verticillane-type diterpene and should be very similar to cespihypotin $\mathrm{H}$ [28] except for the position of a tetrasubstituted epoxide and the hydroxy group in the tetrahydrosubstituted furan ring. Similar to 1 , this tetrasubstituted epoxide was located between $\mathrm{C}-10\left(\delta_{\mathrm{C}} 94.7, \mathrm{C}\right)$ and $\mathrm{C}-11\left(\delta_{\mathrm{C}} 72.4, \mathrm{C}\right)$, and the hydroxy group was found at $\mathrm{C}-12\left(\delta_{\mathrm{C}} 79.8, \mathrm{C}\right)$ on the basis of the assistance of HMBC correlations. The position of the acrylate group at $\mathrm{C}-20$ was also confirmed by the HMBC correlations from $\mathrm{H}-20\left(\delta_{\mathrm{H}} 5.70, \mathrm{~s}\right)$ and $\mathrm{H}-22\left(\delta_{\mathrm{H}} 6.14, \mathrm{dd}, J=17.2,10.4 \mathrm{~Hz}\right)$ to $\mathrm{C}-21\left(\delta_{\mathrm{C}} 164.8, \mathrm{C}\right)$. These observations, together with analysis of other COSY and HMBC correlations, enabled the gross structure of $\mathbf{2}$ to be established reasonably (Figure 3).

The relative configurations of the six chiral centers at C-1, C-6, C-10, C-11, C-12, and C-20 in 2 were also determined from key NOE correlations with an MM2 force field calculation (Figure 4). One proton of $\mathrm{H}_{2}-9\left(\delta_{\mathrm{H}} 2.55, \mathrm{~d}, J=14.4 \mathrm{~Hz}\right)$ showed NOE interaction with the known $\beta$-oriented $\mathrm{H}_{3}-16\left(\delta_{\mathrm{H}} 0.94\right.$, s) and suggested as $\mathrm{H}-9 \beta$, while the other proton at C-9 was assigned as $\mathrm{H}-9 \alpha\left(\delta_{\mathrm{H}} 3.10, \mathrm{~d}, J=14.4 \mathrm{~Hz}\right)$. Similar to 1 , the $E$ geometry of 7,8-trisubstituted double bond was confirmed, as the NOE correlations of H-9 $\beta$ with H-7 and $\mathrm{H}-9 \alpha$ with $\mathrm{H}_{3}-19\left(\delta_{\mathrm{H}} 1.81, \mathrm{~s}\right)$ were found and also from the observation of an upfield chemical shift of C-19 at $17.2 \mathrm{ppm}$ [9]. Moreover, $\mathrm{H}-6\left(\delta_{\mathrm{H}} 4.49, \mathrm{t}, J=8.0 \mathrm{~Hz}\right)$ displayed NOE correlations with one proton of $\mathrm{H}_{2}-5\left(\delta_{\mathrm{H}} 2.65, \mathrm{dd}, J=12.5,3.2 \mathrm{~Hz}\right)$ and $\mathrm{H}_{3}-19$, while $\mathrm{H}-7$ was 
found to correlate with the other proton of $\mathrm{H}_{2}-5\left(\delta_{\mathrm{H}} 2.24, \mathrm{~m}\right)$, reflecting the $\beta$-orientation of hydroxy group at C-6. Furthermore, the NOE correlation observed between the $\beta$-oriented $\mathrm{H}_{3}-17$ and one proton of $\mathrm{H}_{2}-14\left(\delta_{\mathrm{H}} 2.28, \mathrm{~m}\right)$, which also correlated with one proton of $\mathrm{H}_{2}-13$ $\left(\delta_{\mathrm{H}} 1.71, \mathrm{td}, J=14.0,3.6 \mathrm{~Hz}\right)$, suggested the $\beta$-orientation of these two methylene protons at C-14 and C-13, respectively. H-13 $\beta$ exhibited an NOE correlation with $\mathrm{H}-20\left(\delta_{\mathrm{H}} 5.70, \mathrm{~s}\right)$, while $12-\mathrm{OH}\left(\delta_{\mathrm{H}} 2.64\right.$, br s) correlated with $\mathrm{H}-13 \alpha\left(\delta_{\mathrm{H}} 1.58, \mathrm{~m}\right)$ but not with $\mathrm{H}-20$, revealing that the acrylate group at C-20 was $\alpha$-oriented. By conformational searching for 2 using MMFF molecular mechanics model, 13 lowest conformers (Table S2 and Figure S114) of 2 were found and also could explain the observed NOE correlations. From these results and other detailed NOE correlations, the relative configuration of 2 was determined.

Cespitulin J (3) was isolated as a colorless oil. The HRESIMS $\left(\mathrm{m} / \mathrm{z} 611.4282[\mathrm{M}+\mathrm{Na}]^{+}\right)$ and NMR data (Tables 1 and 2) of 3 exhibited a molecular formula of $\mathrm{C}_{36} \mathrm{H}_{60} \mathrm{O}_{6}$, acquiring seven degrees of unsaturation. The IR spectrum suggested the presence of hydroxy $\left(3446 \mathrm{~cm}^{-1}\right)$ and ester carbonyl $\left(1758 \mathrm{~cm}^{-1}\right)$ groups. Comparison of the NMR spectroscopic data of $\mathbf{3}$ and $\mathbf{2}$ indicated that the structure of $\mathbf{3}$ was highly similar to that of $\mathbf{2}$, with the exception of an acrylate ester group in $\mathbf{2}$ being replaced by a long-chain ester moiety in 3 . Furthermore, it is reasonable to elucidate the hexadecanoyl ester group at C-20 $\left(\delta_{\mathrm{C}} 100.8\right.$, $\mathrm{CH}$ ) by HRESIMS and 2D NMR spectroscopic data, including HMBC and COSY correlations. Thus, the structural framework of $\mathbf{3}$ was established to be a verticillane-type diterpene, including a polyoxygenated epoxytetrahydrofuran ring, too (Figure 3). The analysis of the NOESY spectrum revealed that 3 possessed the same relative configurations at C-1, C-6, C-10, C-11, and C-12 as those of compound 2. A difference in the stereochemistry of $\mathrm{H}-20$ between 2 and 3 was demonstrated with the assistance of the NOESY experiment which revealed that H-20 $\left(\delta_{\mathrm{H}} 5.63, \mathrm{~s}\right)$ had an NOESY correlation with $12-\mathrm{OH}\left(\delta_{\mathrm{H}} 2.52\right.$, br s), indicating that $\mathrm{H}-20$ of 3 should be $\alpha$-oriented and accomplished the elucidation of the relative configuration of 3 .

Cespitulin K (4) was obtained as a colorless oi1 that gave a sodiated adduct ion peak at $m / z 637.4440[\mathrm{M}+\mathrm{Na}]^{+}$in the HRESIMS spectrum, suggesting the molecular formula $\mathrm{C}_{38} \mathrm{H}_{62} \mathrm{O}_{6}$ with eight degrees of unsaturation. IR absorptions at 3420 and $1748 \mathrm{~cm}^{-1}$ showed the presence of hydroxy and ester carbonyl functionalities, too. The ${ }^{13} \mathrm{C}$ and ${ }^{1} \mathrm{H}$ NMR spectroscopic data (Tables 1 and 2) of 4 were found to be very similar to those of $\mathbf{3}$, with the exception that the hexadecanoyl ester at C-20 in 3 was converted to the octadecenoyl ester group in 4 by the HRESIMS data and 2D NMR (HMBC and COSY) correlations (Figure 3) of 3 . The remaining one degree of unsaturation has arisen from the cis $C-9^{\prime} / \mathrm{C}-10^{\prime}$ double bond of the octadecenoyl ester group in 4 by comparison of ${ }^{13} \mathrm{C}$ NMR spectroscopic data of this ester side chain at C-20 with those reported previously $[36,37]$. Finally, the $Z$ geometry of the $9^{\prime}, 10^{\prime}$-double bond was also deduced from a $10.5 \mathrm{~Hz}$ coupling constant between $\mathrm{H}-9^{\prime}$ and $\mathrm{H}-10^{\prime}$ in the ${ }^{1} \mathrm{H}$ NMR spectrum.

The relative configuration of 4 was also determined by a NOESY experiment. The NOE correlations of $\mathrm{H}-1\left(\delta_{\mathrm{H}} 1.49, \mathrm{~m}\right), \mathrm{H}_{2}-5\left(\delta_{\mathrm{H}} 2.66, \mathrm{dd}, J=12.5,2.5 \mathrm{~Hz}\right.$ and $\left.2.25, \mathrm{~m}\right), \mathrm{H}-6$ $\left(\delta_{\mathrm{H}} 4.50, \mathrm{~m}\right), \mathrm{H}-7\left(\delta_{\mathrm{H}} 5.47, \mathrm{~d}, J=8.0 \mathrm{~Hz}\right), \mathrm{H}_{2}-9\left(\delta_{\mathrm{H}} 3.09\right.$ and 2.54 , both $\left.\mathrm{d}, J=14.0 \mathrm{~Hz}\right), \mathrm{H}_{3}-16$ $\left(\delta_{\mathrm{H}} 0.98, \mathrm{~s}\right), \mathrm{H}_{3}-17\left(\delta_{\mathrm{H}} 1.33, \mathrm{~s}\right), \mathrm{H}_{3}-19\left(\delta_{\mathrm{H}} 1.81, \mathrm{~s}\right), \mathrm{H}-20\left(\delta_{\mathrm{H}} 5.63, \mathrm{~s}\right)$, and $12-\mathrm{OH}\left(\delta_{\mathrm{H}} 2.53\right.$, br s$)$ were almost the same as those of 3 , suggesting the same configurations at the corresponding carbons in both 3 and 4 . On the basis of the above results, the relative configuration of 4 was established.

Cespitulin L (5) was isolated as a white amorphous powder. Its molecular formula, $\mathrm{C}_{21} \mathrm{H}_{32} \mathrm{O}_{5}$, was established by HRESIMS $\left(m / z 365.2315[\mathrm{M}+\mathrm{H}]^{+}\right)$, implying six degrees of unsaturation. The IR spectrum showed the presence of the hydroxy moiety $\left(3445 \mathrm{~cm}^{-1}\right)$. The ${ }^{13} \mathrm{C}$ and ${ }^{1} \mathrm{H}$ NMR spectroscopic data revealed that 5 was found to possess a 10,20-ether linkage tetrahydrosufuran ring $\left(\delta_{\mathrm{C}} 104.6, \mathrm{CH}, \mathrm{C}-20\right.$ and $\left.94.3, \mathrm{C}, \mathrm{C}-10 ; \delta_{\mathrm{H}} 4.36, \mathrm{~s}, \mathrm{H}-20\right)$ and a 10,11-tetrasubstituted epoxide $\left(\delta_{C} 72.8, C, C-11\right)$, as well as the same verticillane core skeleton of compounds 2-4 (Tables 1 and 2). The presence of a methoxy group at C-20 of 5 was further established by an $\mathrm{HMBC}$ correlation from $\mathrm{H}_{3}-21\left(\delta_{\mathrm{H}} 3.47\right.$, s) to C-20 (Figure 3). These results suggested that the relative configuration of 5 was nearly the same as those 
of 2-4. Further, the 20-acetal proton $\left(\delta_{\mathrm{H}} 4.36\right.$, s) was found to show an NOE interaction with $\mathrm{H}-13 \beta\left(\delta_{\mathrm{H}} 1.70\right.$, br d, $\left.J=14.0 \mathrm{~Hz}\right)$, while the $12-\mathrm{OH}\left(\delta_{\mathrm{H}} 3.29\right.$, s) exhibited interactions with both $\mathrm{H}-13 \alpha\left(\delta_{\mathrm{H}} 1.58, \mathrm{~m}\right)$ and $\mathrm{H}_{3}-21$, indicating the $\beta$-orientation of $\mathrm{H}-20$ and the $\alpha$-orientation of the 21-methoxy group (Figure 4 ).

Cespitulin $\mathrm{M}(6)$ was found to possess the same molecular formula, $\mathrm{C}_{21} \mathrm{H}_{32} \mathrm{O}_{5}$, as that of 5 from the HRESIMS data $\left(387.2142[\mathrm{M}+\mathrm{Na}]^{+}\right)$. Analysis of the 1D NMR spectroscopic data (Tables 1 and 3) and the 2D NMR (HSQC, COSY, and HMBC) correlations enabled the planar structure of $\mathbf{6}$ to be established the same as 5 (Figure 3). The ${ }^{13} \mathrm{C} \mathrm{NMR}$ spectroscopic data of $\mathbf{6}$ were nearly similar to those of $\mathbf{5}$, with the exception of downfield shifts observed at $\mathrm{C}-12\left(\Delta \delta_{\mathrm{C}}+1.6\right)$ and $\mathrm{C}-20\left(\Delta \delta_{\mathrm{C}}+4.5\right)$ relative to 5 , revealing that 6 should be the $\mathrm{C}$ 12 or $\mathrm{C}-20$ isomer of 5 . Further analysis of NOE correlations revealed that 6 possessed the identical relative configurations at C-1, C-6, C-10, C-11, and C-12 as those of 5. A difference in relative configuration for C-20 of the tetrahydrofuran ring between 5 and 6 was characterized by a comparison of their key NOE correlations (Figure 4).

Table 3. ${ }^{1} \mathrm{H}$ NMR spectroscopic data of compounds 6-9, 11, and 12.

\begin{tabular}{|c|c|c|c|c|c|c|}
\hline No. & $6^{1}$ & $7^{1}$ & $8^{1}$ & $9^{1}$ & $11^{1}$ & $12^{1}$ \\
\hline 1 & $1.45, \mathrm{~m}$ & $1.46, \mathrm{~m}$ & $1.49, \mathrm{~m}$ & $1.54, \mathrm{~m}$ & $1.81, \mathrm{~m}$ & $2.15, \mathrm{~m}$ \\
\hline \multirow[t]{2}{*}{2} & $1.79, \mathrm{~m}$ & $1.79, \mathrm{~m}$ & $1.84, \mathrm{~m}$ & $1.55, \mathrm{~m}$ & $1.92, \mathrm{~m}$ & $2.46, \mathrm{~m}$ \\
\hline & $\begin{array}{c}1.11, \mathrm{td} \\
(14.0,5.0)^{2}\end{array}$ & $1.11, \mathrm{~m}$ & $\begin{array}{c}1.11, \mathrm{td} \\
(14.0,5.0)\end{array}$ & $1.36, \mathrm{~m}$ & $1.52, \mathrm{~m}$ & $1.73, \mathrm{~m}$ \\
\hline \multirow[t]{2}{*}{3} & $2.20, \mathrm{~m}$ & $2.23, \mathrm{~m}$ & $2.22, \mathrm{~m}$ & 2.27, m & $\begin{array}{c}2.59, \mathrm{dd} \\
(15.0,11.0)\end{array}$ & $1.94, \mathrm{~m}$ \\
\hline & $2.09, \mathrm{~m}$ & $2.01, \mathrm{~m}$ & $2.08, \mathrm{~m}$ & $2.13, \mathrm{~m}$ & $1.86, \mathrm{~m}$ & $1.56, \mathrm{~m}$ \\
\hline \multirow[t]{2}{*}{5} & $\begin{array}{c}2.64, \mathrm{dd} \\
(13.0,3.0)\end{array}$ & $\begin{array}{c}2.60, \mathrm{dd} \\
(13.0,3.5)\end{array}$ & $\begin{array}{c}2.65, \mathrm{dd} \\
(13.0,3.0)\end{array}$ & $\begin{array}{c}2.44, \mathrm{dd} \\
(13.5,2.5)\end{array}$ & $\begin{array}{c}2.48, \mathrm{dd} \\
(13.0,7.0)\end{array}$ & $2.43, \mathrm{~m}$ \\
\hline & $2.23, \mathrm{~m}$ & $\begin{array}{l}2.30, \mathrm{~d} \\
(13.0)\end{array}$ & $2.24, \mathrm{~m}$ & $2.33, \mathrm{~m}$ & $\begin{array}{c}2.28, \mathrm{dd} \\
(13.0,2.5)\end{array}$ & $\begin{array}{c}2.34, \mathrm{dd} \\
(13.5,3.0)\end{array}$ \\
\hline 6 & $4.51, \mathrm{~m}$ & $5.49, \operatorname{td}(9.0,3.5)$ & 4.50, br t $(8.0)$ & $4.38, \mathrm{~m}$ & $4.49, \mathrm{~m}$ & $4.44, \mathrm{~m}$ \\
\hline 7 & $5.46, \mathrm{~d}(8.0)$ & $5.41, \mathrm{~d}(9.0)$ & $5.48, \mathrm{~d}(9.0)$ & $5.55, \mathrm{~d}(8.0)$ & $5.15, \mathrm{~d}(6.5)$ & $5.28, \mathrm{~d}(7.0)$ \\
\hline \multirow[t]{2}{*}{9} & $3.03, \mathrm{~d}(14.5)$ & $3.04, \mathrm{~d}(14.5)$ & $3.05, \mathrm{~d}(14.5)$ & $3.00, \mathrm{~d}(14.5)$ & $3.43, \mathrm{~d}(15.0)$ & $3.43, \mathrm{~d}(15.5)$ \\
\hline & $2.54, \mathrm{~d}(14.5)$ & $2.55, \mathrm{~d}(14.5)$ & $2.54, \mathrm{~d}(14.5)$ & $2.66, \mathrm{~d}(14.5)$ & $3.08, \mathrm{~d}(15.0)$ & $3.24, \mathrm{~d}(15.5)$ \\
\hline 12 & & & & & $6.10, \mathrm{~d}(3.5)$ & $6.07, \mathrm{~s}$ \\
\hline \multirow[t]{2}{*}{13} & $1.67, \mathrm{~m}$ & $1.76, \mathrm{~m}$ & $1.81, \mathrm{~m}$ & $2.34, \mathrm{~m}$ & $4.50, \mathrm{~m}$ & \\
\hline & $1.56, \mathrm{~m}$ & $1.63, \mathrm{~m}$ & $1.62, \mathrm{~m}$ & $2.18, \mathrm{~m}$ & & \\
\hline \multirow[t]{2}{*}{14} & $2.21, \mathrm{~m}$ & $2.25, \mathrm{~m}$ & $\begin{array}{c}2.30, \mathrm{tt} \\
(14.5,4.0)\end{array}$ & $2.19, \mathrm{~m}$ & $2.13,2 \mathrm{H}, \mathrm{m}$ & $\begin{array}{c}3.02, \mathrm{dd} \\
(18.5,7.0)\end{array}$ \\
\hline & $1.35, \mathrm{~m}$ & $1.33, \mathrm{~m}$ & $1.40, \mathrm{~m}$ & $1.63, \mathrm{~m}$ & & $2.45, \mathrm{~m}$ \\
\hline 16 & $0.98,3 \mathrm{H}, \mathrm{s}$ & $1.00,3 \mathrm{H}, \mathrm{s}$ & $0.98,3 \mathrm{H}, \mathrm{s}$ & $1.47,3 \mathrm{H}, \mathrm{s}$ & $1.09,3 \mathrm{H}, \mathrm{s}$ & $1.23,3 \mathrm{H}, \mathrm{s}$ \\
\hline 17 & $1.31,3 \mathrm{H}, \mathrm{s}$ & $1.33,3 \mathrm{H}, \mathrm{s}$ & $1.33,3 \mathrm{H}, \mathrm{s}$ & $1.24,3 \mathrm{H}, \mathrm{s}$ & $1.40,3 \mathrm{H}, \mathrm{s}$ & $1.51,3 \mathrm{H}, \mathrm{s}$ \\
\hline 18 & $4.92,2 \mathrm{H}, \mathrm{s}$ & $4.96,4.92$, both s & $4.94,2 \mathrm{H}, \mathrm{s}$ & $4.84,2 \mathrm{H}, \mathrm{s}$ & $4.87,4.83$, both s & $4.84,4.78$, both s \\
\hline 19 & $1.84,3 \mathrm{H}, \mathrm{s}$ & $1.88,3 \mathrm{H}, \mathrm{s}$ & $1.83,3 \mathrm{H}, \mathrm{s}$ & $1.58,3 \mathrm{H}, \mathrm{s}$ & $1.76,3 \mathrm{H}, \mathrm{s}$ & $1.78,3 \mathrm{H}, \mathrm{s}$ \\
\hline 20 & $4.47, \mathrm{~s}$ & $\begin{array}{c}3.59,3.43 \\
\text { both d }(9.0)\end{array}$ & $5.76, \mathrm{~s}$ & & & \\
\hline 21 & $3.46,3 \mathrm{H}, \mathrm{s}$ & & & $3.13,3 \mathrm{H}, \mathrm{s}$ & & \\
\hline 22 & & $2.02,3 \mathrm{H}, \mathrm{s}$ & $2.14,3 \mathrm{H}, \mathrm{s}$ & & & \\
\hline $12-\mathrm{OH}$ & 2.63, br s & 1.96, br d (2.0) & 2.68, br s & & & \\
\hline $\mathrm{N}-\mathrm{H}$ & & & & 5.46, br s & & \\
\hline
\end{tabular}

${ }^{1}$ Spectrum recorded at $500 \mathrm{MHz}$ in $\mathrm{CDCl}_{3} .{ }^{2} \mathrm{~J}$ values are in $\mathrm{Hz}$.

Cespitulin $\mathrm{N}(7)$ had the molecular formula $\mathrm{C}_{22} \mathrm{H}_{32} \mathrm{O}_{5}$ as determined by HRESIMS $\left(m / z 399.2142[\mathrm{M}+\mathrm{Na}]^{+}\right)$. The IR spectrum of 7 showed the presence of hydroxy $\left(3446 \mathrm{~cm}^{-1}\right)$ and ester carbonyl $\left(1733 \mathrm{~cm}^{-1}\right)$ groups. All the proton and carbon signals of 7 were assigned from the ${ }^{13} \mathrm{C}$ and ${ }^{1} \mathrm{H}$ NMR spectroscopic data (Tables 3 and 4), along with HSQC spectrum, which established the structure of 7 as a tetracyclic verticillane-type diterpene with an acetoxy group $\left(\delta_{\mathrm{C}} 170.2, \mathrm{C}\right.$ and $\left.21.3, \mathrm{CH}_{3} ; \delta_{\mathrm{H}} 2.02, \mathrm{~s}\right)$. In addition, the NMR data of 7 were found to resemble those of cespitulin G [27]. Detailed analysis of 2D NMR spectra (COSY, 
HMBC, and NOESY), revealed that 7 possesses a 10,20-ether linkage trihydrosubstituted furan ring $\left(\delta_{\mathrm{C}} 95.9, \mathrm{C}, \mathrm{C}-10\right.$ and $75.5, \mathrm{CH}_{2}, \mathrm{C}-20 ; \delta_{\mathrm{H}} 3.59$ and 3.43 , both $\left.\mathrm{d}, J=9.0 \mathrm{~Hz}\right)$, a 10,11-epoxide $\left(\delta_{\mathrm{C}} 74.0, \mathrm{C}, \mathrm{C}-11\right)$, and a hydroxy group at C-12 $\left(\delta_{\mathrm{C}} 78.7, \mathrm{C} ; \delta_{\mathrm{H}} 1.96\right.$, br d, $J=2.0 \mathrm{~Hz}, 12-\mathrm{OH})$. Furthermore, key NOE correlations of the $12-\mathrm{OH}$ to $\mathrm{H}-13 \alpha\left(\delta_{\mathrm{H}} 1.76, \mathrm{~m}\right)$ and $\mathrm{H}-20 \alpha\left(\delta_{\mathrm{H}} 3.43, \mathrm{~d}, J=9.0 \mathrm{~Hz}\right)$ indicated that the 12-hydroxy group should be positioned on the $\alpha$ face.

Table 4. ${ }^{13} \mathrm{C}$ NMR spectroscopic data of compounds 7-9, 11, and 12.

\begin{tabular}{|c|c|c|c|c|c|}
\hline No. & $7^{1}$ & $8^{1}$ & $9^{1}$ & $11^{1}$ & $12^{1}$ \\
\hline 1 & $44.3, \mathrm{CH}^{2}$ & $44.1, \mathrm{CH}$ & $44.8, \mathrm{CH}$ & $45.8, \mathrm{CH}$ & $45.4, \mathrm{CH}$ \\
\hline 2 & $34.2, \mathrm{CH}_{2}$ & $33.7, \mathrm{CH}_{2}$ & $32.4, \mathrm{CH}_{2}$ & $29.5, \mathrm{CH}_{2}$ & $30.7, \mathrm{CH}_{2}$ \\
\hline 3 & $37.8, \mathrm{CH}_{2}$ & $37.7, \mathrm{CH}_{2}$ & $34.4, \mathrm{CH}_{2}$ & $31.0, \mathrm{CH}_{2}$ & $30.6, \mathrm{CH}_{2}$ \\
\hline 4 & $145.3, \mathrm{C}$ & $145.5, \mathrm{C}$ & 146.1, C & 146.0, C & $145.4, C$ \\
\hline 5 & $43.4, \mathrm{CH}_{2}$ & $45.8, \mathrm{CH}_{2}$ & $43.9, \mathrm{CH}_{2}$ & $44.8, \mathrm{CH}_{2}$ & $44.2, \mathrm{CH}_{2}$ \\
\hline 6 & $72.2, \mathrm{CH}$ & $69.2, \mathrm{CH}$ & $68.3, \mathrm{CH}$ & $69.0, \mathrm{CH}$ & $69.5, \mathrm{CH}$ \\
\hline 7 & $128.7, \mathrm{CH}$ & $133.7, \mathrm{CH}$ & $135.7, \mathrm{CH}$ & $133.6, \mathrm{CH}$ & $135.3, \mathrm{CH}$ \\
\hline 8 & $134.5, \mathrm{C}$ & $132.5, \mathrm{C}$ & 131.3, C & $130.0, \mathrm{C}$ & 129.1, C \\
\hline 9 & $41.3, \mathrm{CH}_{2}$ & $40.6, \mathrm{CH}_{2}$ & $48.5, \mathrm{CH}_{2}$ & $51.9, \mathrm{CH}_{2}$ & $52.4, \mathrm{CH}_{2}$ \\
\hline 10 & $95.9, \mathrm{C}$ & 95.1, C & $93.9, \mathrm{C}$ & 202.6, C & 202.2, C \\
\hline 11 & $74.0, \mathrm{C}$ & $73.0, \mathrm{C}$ & $160.1, \mathrm{C}$ & 150.3, C & $166.0, \mathrm{C}$ \\
\hline 12 & $78.7, \mathrm{C}$ & $78.5, \mathrm{C}$ & $133.8, \mathrm{CH}$ & $134.6, \mathrm{CH}$ & $128.6, \mathrm{CH}$ \\
\hline 13 & 31.1, $\mathrm{CH}_{2}$ & $30.6, \mathrm{CH}_{2}$ & $17.5, \mathrm{CH}_{2}$ & $65.9, \mathrm{CH}$ & $199.0, \mathrm{C}$ \\
\hline 14 & $26.2, \mathrm{CH}_{2}$ & 26.0, $\mathrm{CH}_{2}$ & $24.8, \mathrm{CH}_{2}$ & $34.9, \mathrm{CH}_{2}$ & $40.0, \mathrm{CH}_{2}$ \\
\hline 15 & $37.5, \mathrm{C}$ & $37.4, \mathrm{C}$ & $37.7, \mathrm{C}$ & $35.8, \mathrm{C}$ & $37.0, \mathrm{C}$ \\
\hline 16 & $25.2, \mathrm{CH}_{3}$ & $25.0, \mathrm{CH}_{3}$ & $24.8, \mathrm{CH}_{3}$ & $23.8, \mathrm{CH}_{3}$ & $23.6, \mathrm{CH}_{3}$ \\
\hline 17 & 26.3, $\mathrm{CH}_{3}$ & $26.0, \mathrm{CH}_{3}$ & $34.1, \mathrm{CH}_{3}$ & $33.4, \mathrm{CH}_{3}$ & $32.3, \mathrm{CH}_{3}$ \\
\hline 18 & $115.8, \mathrm{CH}_{2}$ & $115.9, \mathrm{CH}_{2}$ & $114.8, \mathrm{CH}_{2}$ & $112.6, \mathrm{CH}_{2}$ & $113.4, \mathrm{CH}_{2}$ \\
\hline 19 & $17.5, \mathrm{CH}_{3}$ & $17.4, \mathrm{CH}_{3}$ & 17.6, $\mathrm{CH}_{3}$ & $18.8, \mathrm{CH}_{3}$ & $18.9, \mathrm{CH}_{3}$ \\
\hline 20 & $75.5, \mathrm{CH}_{2}$ & 96.1, CH & $171.6, \mathrm{C}$ & & \\
\hline 21 & $170.2, \mathrm{C}$ & $169.7, \mathrm{C}$ & $50.4, \mathrm{CH}_{3}$ & & \\
\hline 22 & 21.3, $\mathrm{CH}_{3}$ & $21.2, \mathrm{CH}_{3}$ & & & \\
\hline
\end{tabular}

${ }^{1}$ Spectrum recorded at $500 \mathrm{MHz}$ in $\mathrm{CDCl}_{3} .{ }^{2}$ Multiplicities deduced by the HSQC experiment.

The protonated adduct ion peak $[\mathrm{M}+\mathrm{H}]^{+}$of cespitulin $\mathrm{O}(8)$ at $m / z$ 393.2267 in HRESIMS indicated a molecular formula $\mathrm{C}_{22} \mathrm{H}_{32} \mathrm{O}_{6}$. The IR absorptions showed the presence of the hydroxy $\left(3419 \mathrm{~cm}^{-1}\right)$ and an ester carbonyl $\left(1733 \mathrm{~cm}^{-1}\right)$ groups. The ${ }^{13} \mathrm{C}$ and ${ }^{1} \mathrm{H}$ spectroscopic data (Tables 3 and 4) of 8 were very similar to those of cespihypotin I [28] and had the same molecular formula. However, the gross structure of $\mathbf{8}$ was established as a 10,11-epoxy-10,11,12,20-tetrahydrosubstituted-furanyl diterpene containing an acetoxy group at C-20 by the results of 2D NMR experiments (including COSY and HMBC correlations, Figure 5). Further analysis of the NOE correlations revealed that $\mathrm{H}-20\left(\delta_{\mathrm{H}} 5.76, \mathrm{~s}\right)$ showed NOE interaction with $\mathrm{H}-13 \beta\left(\delta_{\mathrm{H}} 1.81, \mathrm{~m}\right)$, while $12-\mathrm{OH}\left(\delta_{\mathrm{H}} 2.68\right.$, br s) with $\mathrm{H}-13 \alpha$ $\left(\delta_{\mathrm{H}} 1.62, \mathrm{~m}\right)$, confirming the $\beta$-orientation of the acetoxy group at $\mathrm{C}$-20 (Figure 6 ).

The assignment of the relative stereochemistry of the nonprotonated carbons $\mathrm{C}-10$ and C-11 of the epoxy ring in compounds 1-8 was also based on the observed NOE correlations and molecular model calculation. For example, the relative configurations of C-10 and C-11 of compound 5 as shown in Figure 7 were assigned on the basis that the distance between $\mathrm{H}_{3}-16$ and one proton of $\mathrm{H}_{2}-9$ is $2.22 \AA$ and that between $\mathrm{H}_{3}-17$ and this proton of $\mathrm{H}_{2}-9$ is $4.01 \AA$ in the molecular model generated from MM2 calculation, which well match the NOE correlation observed between $\mathrm{H}_{3}-16$ and this proton of $\mathrm{H}_{2}-9$, and not fit the correlations between $\mathrm{H}_{3}-17$ and the same proton at C-9. Moreover, for the conformer of the isomeric 10,11-epoxide (Figure 8), the NOE correlations for $\mathrm{H}_{3}-17 / \mathrm{H}-20$, and between both $\mathrm{H}_{3}-16$ and $\mathrm{H}_{3}-17$ with this $\mathrm{H}-9$ should be found as the distances of $\mathrm{H}_{3}-17 / \mathrm{H}-20, \mathrm{H}_{3}-16$, and $\mathrm{H}_{3}-17$ with this $\mathrm{H}-9$ proton were calculated to be $3.11,2.13$, and $3.16 \AA$, respectively. However, only the NOE correlation between $\mathrm{H}_{3}-16$ and this specific $\mathrm{H}-9$ was detected, suggesting the relative configuration of 5 and the other related compounds should be the same as those described in Figure 1. 


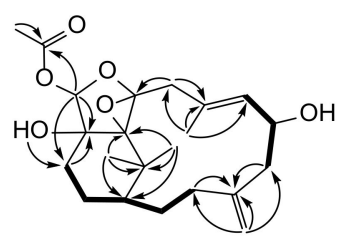

8

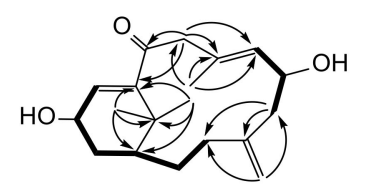

11

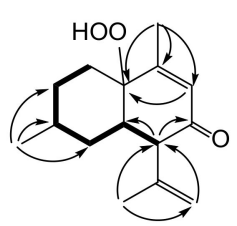

15

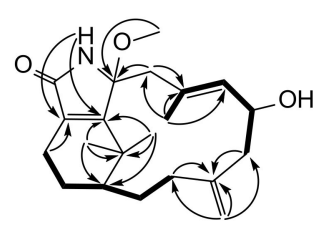

9

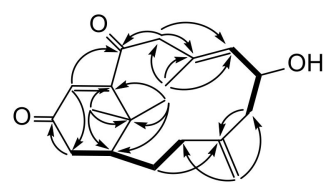

12

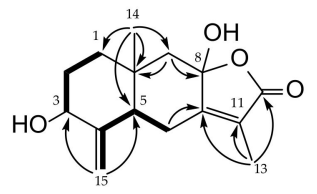

16

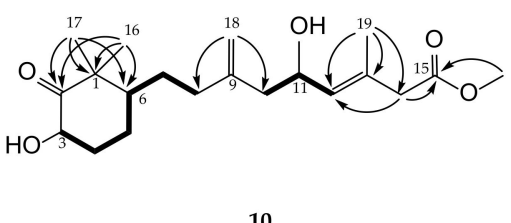

10

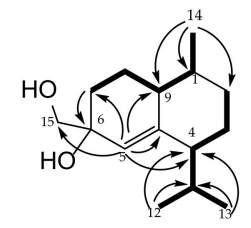

13 and 14

Figure 5. Selected COSY and HMBC correlations of 8-16.

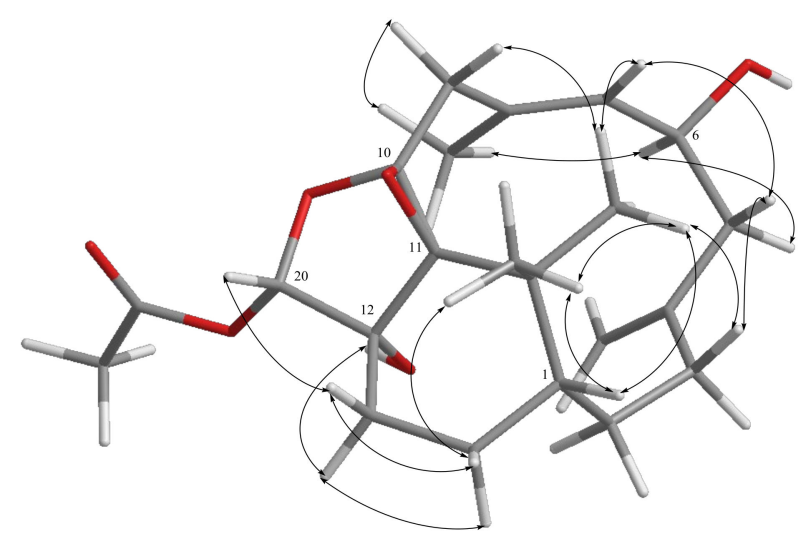

Figure 6. Selected NOE correlations of compound 8.

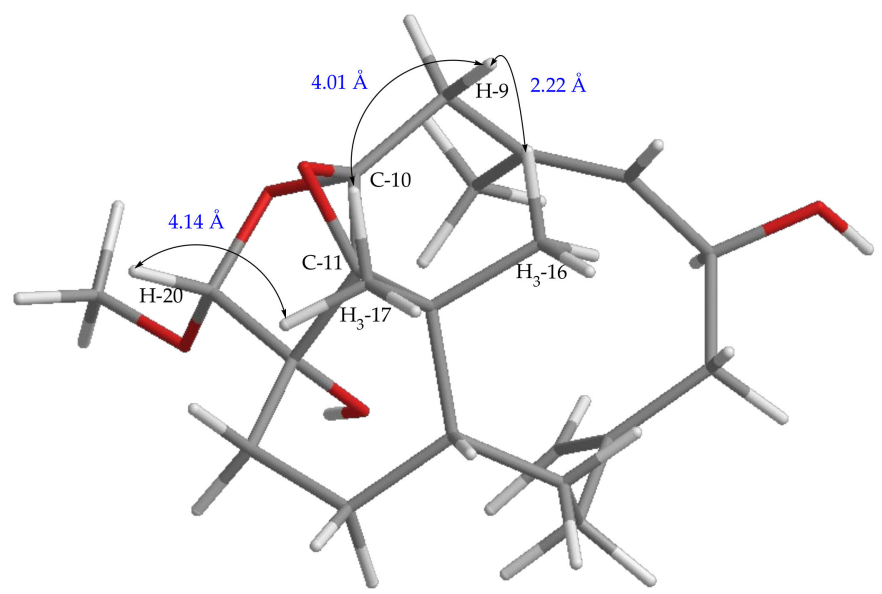

Figure 7. The distance $\mathrm{H}_{3}-16 / \mathrm{H}-9, \mathrm{H}_{3}-17 / \mathrm{H}-9$, and $\mathrm{H}_{3}-17 / \mathrm{H}-20$ of the relative configuration of $\mathrm{C}-10$ and $\mathrm{C}-11$ in compound 5 . 


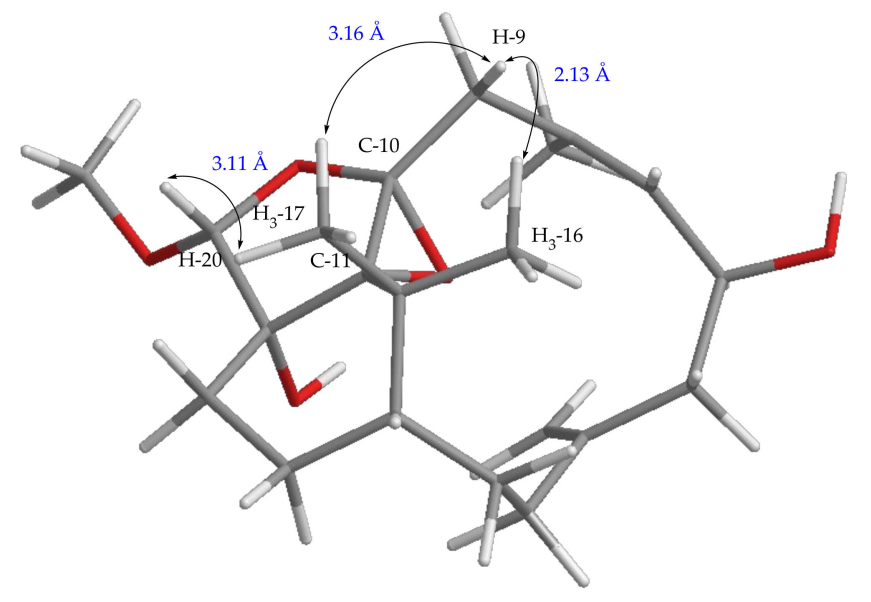

Figure 8. The distance $\mathrm{H}_{3}-16 / \mathrm{H}-9, \mathrm{H}_{3}-17 / \mathrm{H}-9$, and $\mathrm{H}_{3}-17 / \mathrm{H}-20$ of the relative configuration of $\mathrm{C}-10$ and $\mathrm{C}-11$ in isomeric compound 5 .

The HRESIMS data $\left(\mathrm{m} / z 368.2195[\mathrm{M}+\mathrm{Na}]^{+}\right)$of cespitulactam $\mathrm{L}(9)$ established the molecular formula $\mathrm{C}_{21} \mathrm{H}_{31} \mathrm{O}_{3} \mathrm{~N}$, consistent with seven degrees of unsaturation. The IR spectrum suggested the presence of hydroxy and/or amide $\left(3245 \mathrm{~cm}^{-1}\right)$ and conjugated carbonyl $\left(1698 \mathrm{~cm}^{-1}\right)$ groups. Compound 9 and cespitulactam F [22] were found to have the same $\alpha, \beta$-unsaturated lactam ring by comparison of their 1D and 2D NMR spectroscopic data. Likewise, the ${ }^{1} \mathrm{H}$ and ${ }^{13} \mathrm{C}$ NMR data of 9 (Tables 3 and 4 ) were highly similar with those of cespitulactam $\mathrm{F}$, with the difference that the presence of a methoxy group $\left(\delta_{\mathrm{C}}\right.$ $\left.50.4, \mathrm{CH}_{3} ; \delta_{\mathrm{H}} 3.13, \mathrm{~s}\right)$ at $\mathrm{C}-10\left(\delta_{\mathrm{C}} 93.9, \mathrm{C}\right)$ in 9 was found, instead of a hydroxy group in cespitulactam F. Cespitulactam L (9) is the 10-methoxy derivative of cespitulactam F. The relative stereochemistry of 9 was deduced from the analysis of the observed NOE correlations. The known $\beta$-oriented $\mathrm{H}_{3}-17\left(\delta_{\mathrm{H}} 1.24\right.$, s) exhibited NOE interactions with the methoxy protons $\left(\delta_{\mathrm{H}} 3.13, \mathrm{~s}\right)$, indicating the $\beta$-orientation of 10-methoxy group. By the biogenetic consideration and other detailed NOE correlations (Figure 9), cespitulactam L (9) was found to possess the same relative configuration as that of cespitulactam F.
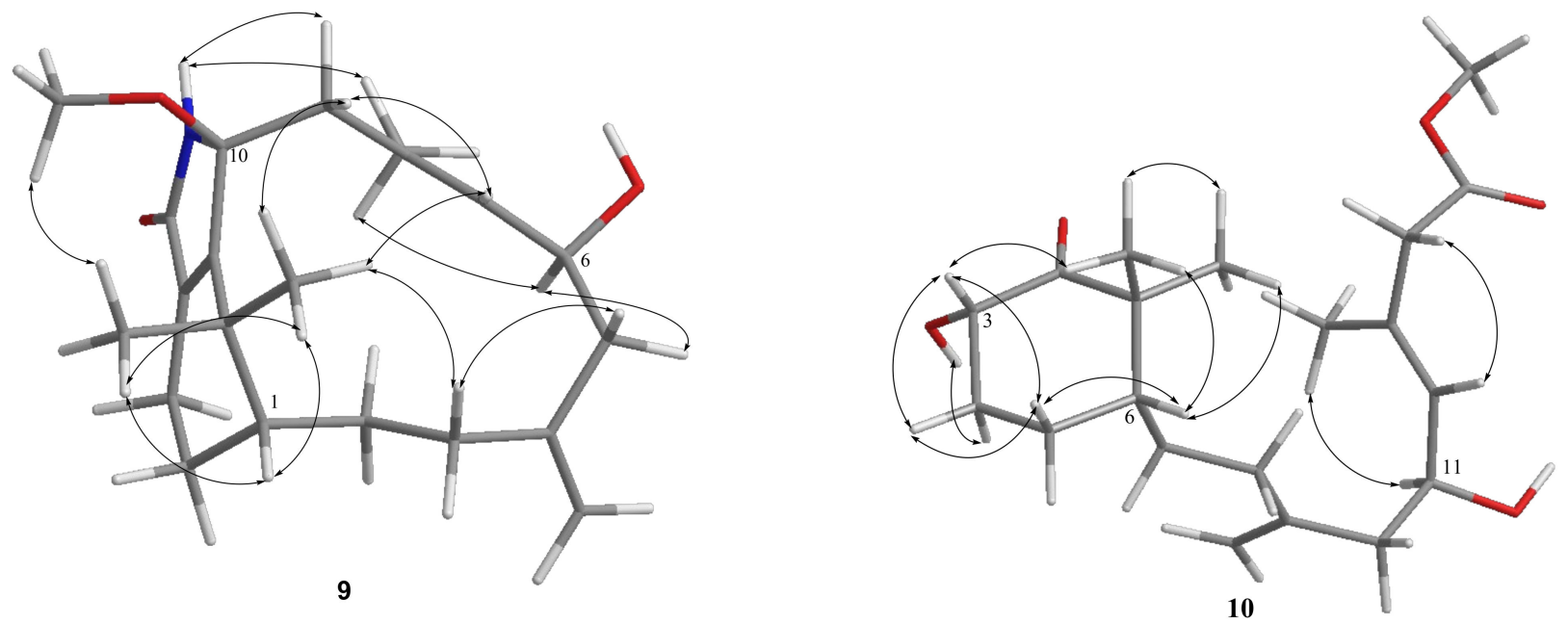

Figure 9. Selected NOE correlations of compounds 9 and 10.

2.2. Structure Elucidation of a Novel Norditerpene $\mathbf{1 0}$ and the Verticillane-Type Norditerpenes $\mathbf{1 1}$ and 12

Compound 10 exhibited a sodiated ion peak at $m / z 375.2141[\mathrm{M}+\mathrm{Na}]^{+}$in the HRESIMS, establishing a molecular formula $\mathrm{C}_{20} \mathrm{H}_{32} \mathrm{O}_{5}$ and implying five degrees of unsaturation. The presence of the hydroxy, ester carbonyl, and ketone groups was observed by IR ab- 
sorptions at 3445,1732 , and $1715 \mathrm{~cm}^{-1}$, respectively. The ${ }^{13} \mathrm{C}$ and ${ }^{1} \mathrm{H}$ NMR data (Table 5) of 10 revealed that three degrees of unsaturation were contributed from a 1,1-disubstituted double bond $\left(\delta_{\mathrm{C}} 147.1, \mathrm{C}\right.$ and $\left.113.2, \mathrm{CH}_{2} ; \delta_{\mathrm{H}} 4.87, \mathrm{~s}\right)$, a trisubstituted double bond $\left(\delta_{\mathrm{C}} 131.7\right.$, $\mathrm{CH}$ and $\left.122.2, \mathrm{C} ; \delta_{\mathrm{H}} 5.32, \mathrm{~d}, J=8.5 \mathrm{~Hz}\right)$, and an ester carbonyl $\left(\delta_{\mathrm{C}} 171.4, \mathrm{C}\right)$. The remaining two degrees of unsaturation were arisen from a 2-hydroxy-6,6-dimethylcyclohexan-1-one moiety by inspection of 2D NMR correlations (Figure 5). The NMR spectroscopic data of $\mathbf{1 0}$ resemble those of known norditerpenoid cespitularin $Q(17)[18,26]$, except for the presence of a methoxy group $\left(\delta_{\mathrm{C}} 51.8, \mathrm{CH}_{3} ; \delta_{\mathrm{H}} 3.69, \mathrm{~s}\right)$ at $\mathrm{C}-15\left(\delta_{\mathrm{C}} 171.4, \mathrm{C}\right)$ and a hydroxy group at $\mathrm{C}-3\left(\delta_{\mathrm{C}} 71.4, \mathrm{CH}\right)$ in 10 , and also the absence of a 14-membered lactone ring linkage between $\mathrm{C}-10\left(\delta_{\mathrm{C}} 169.7, \mathrm{C}\right)$ and $\mathrm{C}-12\left(\delta_{\mathrm{C}} 72.2, \mathrm{CH}\right)$ which is present in 17 , indicating that a linear terpenoidal ester 10 might be arisen from cespitularin $Q$ by hydrolysis and further esterification. It was also found that the molecular skeleton of $\mathbf{1 0}$ is nearly the same as that of retinoids with missing of the methyl group at $C-5$, while normal retinoids are originated from the oxidative cleavage of $\beta$-carotene [38]. In the NOESY spectrum, a strong interaction between $\mathrm{H}-6 \beta\left(\delta_{\mathrm{H}} 1.79, \mathrm{~m}\right)$ and $\mathrm{H}_{3}-17\left(\delta_{\mathrm{H}} 1.32, \mathrm{~s}\right)$ showed the $\beta$-orientation of $\mathrm{H}_{3}$-17. Further, $\mathrm{H}-3\left(\delta_{\mathrm{H}} 4.45, \mathrm{~m}\right)$ showed NOE correlations with both $\mathrm{H}_{3}-17$ and one proton of $\mathrm{H}-4\left(\delta_{\mathrm{H}} 2.31, \mathrm{~m}\right)$, as did the $3-\mathrm{OH}\left(\delta_{\mathrm{H}} 3.67, \mathrm{br} \mathrm{d}, J=3.5 \mathrm{~Hz}\right)$ with the other proton of $\mathrm{H}-4\left(\delta_{\mathrm{H}} 1.58, \mathrm{~m}\right)$, reflecting that $\mathrm{H}-3$ should be $\beta$-oriented while the hydroxy group at C-3 was assigned as $\alpha$-oriented (Figure 9). By the analysis of the above NOE correlations and the biosynthetic relation of $\mathbf{1 0}$ and $\mathbf{1 7}$, the relative configuration of $\mathbf{1 0}$ was elucidated and named cespitulin $P$.

Table 5. ${ }^{1} \mathrm{H}$ and ${ }^{13} \mathrm{C}$ NMR spectroscopic data of compound $\mathbf{1 0 .}$

\begin{tabular}{|c|c|c|}
\hline \multirow[b]{2}{*}{ No. } & \multicolumn{2}{|c|}{10} \\
\hline & ${ }^{1} \mathbf{H}^{1}$ & ${ }^{13} C^{2}$ \\
\hline 1 & & $48.4, \mathrm{C}$ \\
\hline 2 & & $214.6, \mathrm{C}$ \\
\hline 3 & $4.45, \mathrm{~m}$ & $71.4, \mathrm{CH}^{4}$ \\
\hline \multirow[t]{2}{*}{4} & $2.31, \mathrm{~m}$ & $31.6, \mathrm{CH}_{2}$ \\
\hline & $1.58, \mathrm{~m}$ & \\
\hline \multirow[t]{2}{*}{5} & $2.13, \mathrm{~m}$ & $21.0, \mathrm{CH}_{2}$ \\
\hline & $1.68, \mathrm{~m}$ & \\
\hline 6 & $1.79, \mathrm{~m}$ & $46.9, \mathrm{CH}$ \\
\hline \multirow[t]{2}{*}{7} & $1.64, \mathrm{~m}$ & $25.7, \mathrm{CH}_{2}$ \\
\hline & $1.13, \mathrm{~m}$ & \\
\hline \multirow[t]{2}{*}{8} & $2.11, \mathrm{~m}$ & $33.8, \mathrm{CH}_{2}$ \\
\hline & $1.92, \mathrm{~m}$ & \\
\hline 9 & & 147.1, C \\
\hline 10 & $2.20,2 \mathrm{H}, \mathrm{m}$ & $43.9, \mathrm{CH}_{2}$ \\
\hline 11 & $4.47, \mathrm{~m}$ & $66.1, \mathrm{CH}$ \\
\hline 12 & 5.32, br d $(8.5)^{3}$ & $131.7, \mathrm{CH}$ \\
\hline 13 & & $122.2, \mathrm{C}$ \\
\hline 14 & $3.02,2 \mathrm{H}$, br s & $44.6, \mathrm{CH}_{2}$ \\
\hline 15 & & $171.4, \mathrm{C}$ \\
\hline 16 & $1.11,3 \mathrm{H}, \mathrm{s}$ & $21.8, \mathrm{CH}_{3}$ \\
\hline 17 & $1.32,3 \mathrm{H}, \mathrm{s}$ & $27.0, \mathrm{CH}_{3}$ \\
\hline 18 & $4.87,2 \mathrm{H}, \mathrm{s}$ & $113.2, \mathrm{CH}_{2}$ \\
\hline 19 & $1.77,3 \mathrm{H}, \mathrm{s}$ & $16.9, \mathrm{CH}_{3}$ \\
\hline 20 & $3.69,3 \mathrm{H}, \mathrm{s}$ & $51.8, \mathrm{CH}_{3}$ \\
\hline
\end{tabular}

${ }^{1}$ Spectrum recorded at $500 \mathrm{MHz}$ in $\mathrm{CDCl}_{3} .{ }^{2}$ Spectrum recorded at $125 \mathrm{MHz}$ in $\mathrm{CDCl}_{3} .{ }^{3} \mathrm{~J}$ values are in $\mathrm{Hz}$

${ }^{4}$ Multiplicities deduced by the HSQC experiment.

The new norditerpene cespitulin $\mathrm{Q}$ (11) was obtained as a colorless oil, which showed the pseudomolecular ion peak $[\mathrm{M}+\mathrm{H}]^{+}$at $m / z 305.2108$ in HRESIMS, appropriate for the molecular formula of $\mathrm{C}_{19} \mathrm{H}_{28} \mathrm{O}_{3}$ and six degrees of unsaturation. The IR absorptions at 3418 and $1699 \mathrm{~cm}^{-1}$ indicated the presence of the hydroxy and carbonyl groups, respectively. The carbon NMR signals (Table 4) at $\delta_{C} 202.6(\mathrm{C}), 150.3(\mathrm{C})$, and $134.6(\mathrm{CH})$, as well as the 
proton NMR signal (Table 3) at $\delta_{\mathrm{H}} 6.10(\mathrm{~d}, J=3.5 \mathrm{~Hz})$, were characteristic resonances for an $\alpha, \beta$-unsaturated ketone unit in $\mathbf{1 1}$.

The analyses of COSY and HMBC correlations were used to establish the planar structure of $\mathbf{1 1}$ (Figure 5). Moreover, the NMR spectroscopic data of $\mathbf{1 1}$ were found to close to those of known metabolite cespitularin E (18) [17], with the exception of the carbon signal of C-13 resonating at $\delta_{\mathrm{C}} 23.9\left(\mathrm{CH}_{2}\right)$ in $\mathbf{1 8}$ was downfield shifted to $\delta_{\mathrm{C}} 65.9(\mathrm{CH})$ in $\mathbf{1 1}$, suggesting that $\mathbf{1 1}$ is the $\mathrm{C}-13$ oxidation derivative of cespitularin $\mathrm{E}(\mathbf{1 8})$. From the NOE correlations (Figure 10) of 11, one of the methylene protons at C-3 $\left(\delta_{\mathrm{H}} 2.59, \mathrm{dd}, J=15.0\right.$, $11.0 \mathrm{~Hz})$ displayed an NOE correlation with the $\beta$-oriented $\mathrm{H}_{3}-16\left(\delta_{\mathrm{H}} 1.09\right.$, s), which correlated with the known $\beta$-oriented $\mathrm{H}-1\left(\delta_{\mathrm{H}} 1.81, \mathrm{~m}\right)$, and thus was characterized as $\mathrm{H}$ $3 \beta$, while the other $\left(\delta_{\mathrm{H}} 1.86, \mathrm{~m}\right)$ was assigned as $\mathrm{H}-3 \alpha$. The NOE correlation between $\mathrm{H}-13$ $\left(\delta_{\mathrm{H}} 4.50, \mathrm{~m}\right)$ and $\mathrm{H}-3 \alpha$ determined the $\beta$-orientation of the hydroxy group at $\mathrm{C}-13$. From the all NOE correlations observed, the relative configuration of $\mathbf{1 1}$ was thus established.
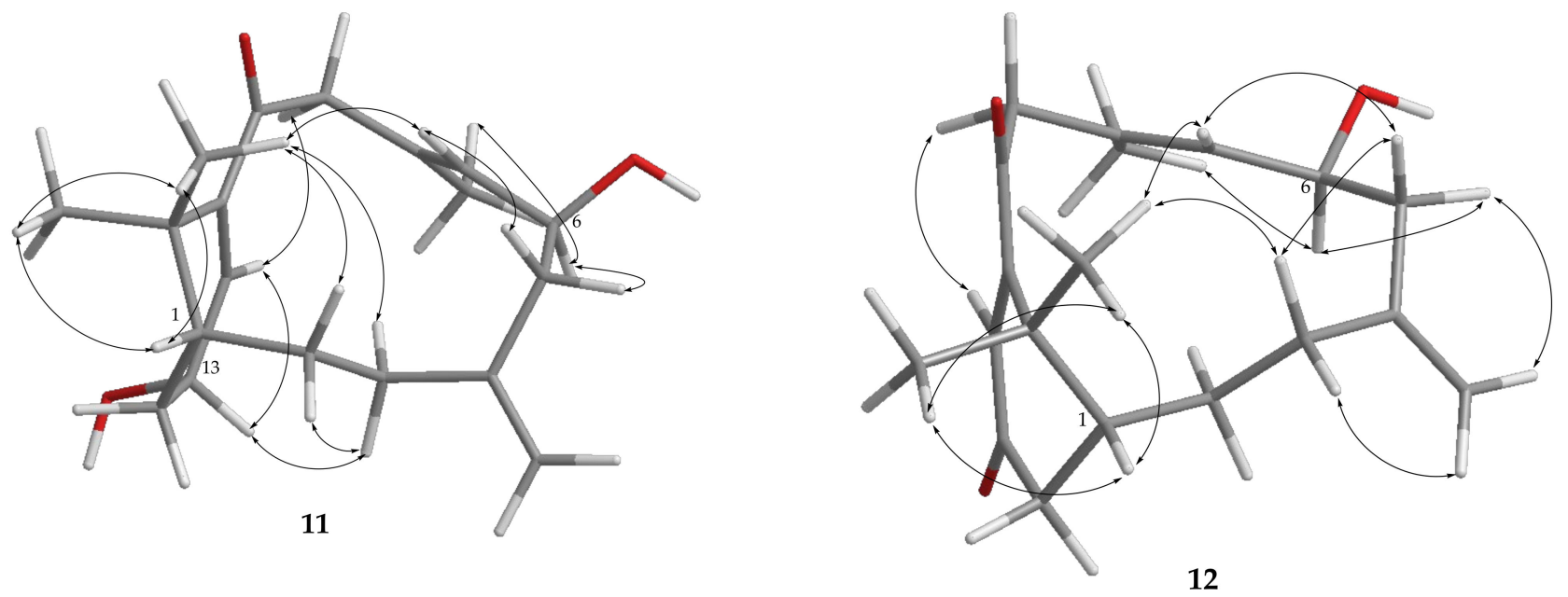

Figure 10. Selected NOE correlations of compounds $\mathbf{1 1}$ and $\mathbf{1 2 .}$

The molecular formula of cespitulin $\mathrm{R}$ (12) was found to be $\mathrm{C}_{19} \mathrm{H}_{26} \mathrm{O}_{3}$, as deduced by HRESIMS $\left(m / z 325.1777[\mathrm{M}+\mathrm{Na}]^{+}\right)$. IR absorptions at 3420 and $1748 \mathrm{~cm}^{-1}$ of the corresponding hydroxy and carbonyl moieties were also confirmed. Comparison of the ${ }^{1} \mathrm{H}$ and ${ }^{13} \mathrm{C}$ NMR spectroscopic data (Tables 3 and 4) of $\mathbf{1 1}$ and $\mathbf{1 2}$ suggested that both compounds are the same bicyclic verticillane-type norditerpenes, except that a hydroxy group at $\mathrm{C}-13\left(\delta_{\mathrm{C}} 65.9, \mathrm{CH} ; \delta_{\mathrm{H}} 4.50, \mathrm{~m}\right)$ in 11 was replaced by a ketone $\left(\delta_{\mathrm{C}} 199.0, \mathrm{C}\right)$ in 12. The planar structure of $\mathbf{1 2}$ was further determined from analysis of the HMBC and COSY correlations, as shown in Figure 5. From the above results and on the basis of the analysis of NOE correlations (Figure 10), the relative configuration of cespitulin R (12) was established.

\subsection{Structure Elucidation of the Cadinane-Type Sesquiterpenes 13-15 and the Eudesmane-Type Sesquiterpenoid 16}

The molecular formula $\mathrm{C}_{15} \mathrm{H}_{26} \mathrm{O}_{2}$ of cespilin A (13) was revealed from the HRESIMS spectrum $\left(m / z 261.1824[\mathrm{M}+\mathrm{Na}]^{+}\right)$. The IR spectrum of 13 showed the presence of the hydroxy group at $3392 \mathrm{~cm}^{-1}$. The ${ }^{13} \mathrm{C}$ NMR (Table 6) and ${ }^{1} \mathrm{H}$ NMR (Table 7), with the assistance of HSQC spectra, showed signals of three methyls, five methylenes (including one oxymethylene), five methines, and two nonprotonated carbons. The gross structure of $\mathbf{1 3}$ was determined by the analysis of COSY and HMBC correlations (Figure 5). The cadinane skeleton of $\mathbf{1 3}$, including placement of a hydroxy group and a hydroxymethyl group at $\mathrm{C}-6\left(\delta_{\mathrm{C}} 71.2, \mathrm{C}\right)$, was established mainly by the $\mathrm{HMBC}$ correlations from $\mathrm{H}_{3}-14$ $\left(\delta_{\mathrm{H}} 0.84, \mathrm{~d}, J=6.8 \mathrm{~Hz}\right)$ to $\mathrm{C}-1\left(\delta_{\mathrm{C}} 34.7, \mathrm{CH}\right), \mathrm{C}-2\left(\delta_{\mathrm{C}} 29.1, \mathrm{CH}_{2}\right)$, and $\mathrm{C}-9\left(\delta_{\mathrm{C}} 36.6, \mathrm{CH}\right)$; isopropyl methyls $\left(\delta_{\mathrm{H}} 0.92\right.$ and 0.78 , both $\left.\mathrm{d}, J=6.8 \mathrm{~Hz}\right)$ to $\mathrm{C}-4\left(\delta_{\mathrm{C}} 51.1, \mathrm{CH}\right)$; olefinic proton 
$\mathrm{H}-5\left(\delta_{\mathrm{H}} 5.45, \mathrm{~s}\right)$ to $\mathrm{C}-4, \mathrm{C}-7\left(\delta_{\mathrm{C}} 31.1, \mathrm{CH}_{2}\right), \mathrm{C}-9, \mathrm{C}-10\left(\delta_{\mathrm{C}} 147.0, \mathrm{C}\right)$, and $\mathrm{C}-15\left(\delta_{\mathrm{C}} 68.9, \mathrm{CH}_{2}\right)$, and $\mathrm{H}_{2}-7\left(\delta_{\mathrm{H}} 1.83, \mathrm{~m}\right.$, and $\left.1.46, \mathrm{~d}, J=9.2 \mathrm{~Hz}\right)$ to $\mathrm{C}-6$.

Table 6. ${ }^{13} \mathrm{C}$ NMR spectroscopic data of compounds 13-16.

\begin{tabular}{|c|c|c|c|c|}
\hline No. & $13^{1}$ & $14^{2}$ & $15^{3}$ & $16^{2}$ \\
\hline 1 & $34.7, \mathrm{CH}^{4}$ & $33.6, \mathrm{CH}$ & $162.7, \mathrm{C}$ & $35.2, \mathrm{CH}_{2}$ \\
\hline 2 & $29.1, \mathrm{CH}_{2}$ & $28.8, \mathrm{CH}_{2}$ & $128.6, \mathrm{CH}$ & $29.0, \mathrm{CH}_{2}$ \\
\hline 3 & 22.7, $\mathrm{CH}_{2}$ & $22.5, \mathrm{CH}_{2}$ & 197.7, C & 72.7, $\mathrm{CH}$ \\
\hline 4 & $51.1, \mathrm{CH}$ & $50.9, \mathrm{CH}$ & $57.1, \mathrm{CH}$ & $149.8, \mathrm{C}$ \\
\hline 5 & $125.8, \mathrm{CH}$ & $125.4, \mathrm{CH}$ & $31.7, \mathrm{CH}_{2}$ & $45.6, \mathrm{CH}$ \\
\hline 6 & $71.2, \mathrm{CH}$ & $70.8, \mathrm{CH}$ & $25.1, \mathrm{CH}$ & 24.0, $\mathrm{CH}_{2}$ \\
\hline 7 & $31.1, \mathrm{CH}_{2}$ & $31.4, \mathrm{CH}_{2}$ & $29.1, \mathrm{CH}_{2}$ & $159.4, C$ \\
\hline 8 & 23.2, $\mathrm{CH}_{2}$ & 22.3, $\mathrm{CH}_{2}$ & $29.8, \mathrm{CH}_{2}$ & 103.1, C \\
\hline 9 & $36.6, \mathrm{CH}$ & $37.5, \mathrm{CH}$ & $84.0, \mathrm{C}$ & 51.0, $\mathrm{CH}_{2}$ \\
\hline 10 & 147.0, C & $146.1, \mathrm{C}$ & $36.8, \mathrm{CH}$ & $36.6, \mathrm{C}$ \\
\hline 11 & $26.6, \mathrm{CH}$ & $26.8, \mathrm{CH}$ & $140.5, \mathrm{C}$ & $123.8, \mathrm{C}$ \\
\hline 12 & 21.2, $\mathrm{CH}_{3}$ & 21.3, $\mathrm{CH}_{3}$ & $18.3, \mathrm{CH}_{3}$ & $174.7, \mathrm{C}$ \\
\hline 13 & 21.7, $\mathrm{CH}_{3}$ & $21.6, \mathrm{CH}_{3}$ & $117.1, \mathrm{CH}_{2}$ & $8.34, \mathrm{CH}_{3}$ \\
\hline 14 & $14.4, \mathrm{CH}_{3}$ & $14.4, \mathrm{CH}_{3}$ & $18.0, \mathrm{CH}_{3}$ & $15.9, \mathrm{CH}_{3}$ \\
\hline 15 & $68.9, \mathrm{CH}_{2}$ & $69.9, \mathrm{CH}_{2}$ & $22.1, \mathrm{CH}_{3}$ & $110.1, \mathrm{CH}_{2}$ \\
\hline
\end{tabular}

${ }^{1}$ Spectrum recorded at $400 \mathrm{MHz}$ in $\mathrm{CDCl}_{3} .{ }^{2}$ Spectrum recorded at $600 \mathrm{MHz}$ in $\mathrm{CDCl}_{3} .{ }^{3}$ Spectrum recorded at $500 \mathrm{MHz}$ in $\mathrm{CDCl}_{3}{ }^{4}$ Multiplicities deduced by the HSQC experiment.

Table 7. ${ }^{1} \mathrm{H}$ NMR spectroscopic data of compounds $\mathbf{1 3 - 1 6 .}$

\begin{tabular}{|c|c|c|c|c|}
\hline No. & $13^{1}$ & $14^{2}$ & $15^{3}$ & $16^{2}$ \\
\hline 1 & $1.96, \mathrm{~m}$ & $1.97, \mathrm{~m}$ & & $\begin{array}{c}1.71 \mathrm{td}(13.8,4.2) \\
1.38, \mathrm{~m}\end{array}$ \\
\hline \multirow[t]{2}{*}{2} & $1.82, \mathrm{~m}$ & $1.82, \mathrm{~m}$ & $5.95, \mathrm{~d}(1.0)$ & $1.87 \mathrm{dt}(14.4,3.6)$ \\
\hline & 1.31 , br t $(10.8)^{4}$ & $1.35, \mathrm{dd}(10.8,4.8)$ & & $1.78 \mathrm{dtd}(14.4,4.2,2.4)$ \\
\hline \multirow[t]{2}{*}{3} & $1.70, \mathrm{~m}$ & $1.70, \mathrm{~m}$ & & 4.37, br s \\
\hline & $1.66, \mathrm{~m}$ & $1.65, \mathrm{~m}$ & & \\
\hline 4 & $1.63, \mathrm{~m}$ & $1.64, \mathrm{~m}$ & $3.26, \mathrm{~d}(13.5)$ & \\
\hline 5 & $5.45, \mathrm{~s}$ & $5.50, \mathrm{~s}$ & $1.46, \mathrm{~m}$ & 2.45, br s \\
\hline \multirow[t]{2}{*}{6} & & & $1.61, \mathrm{~m}$ & $2.60, \mathrm{~d}(10.2)$ \\
\hline & & & & $2.44, \mathrm{~d}(10.2)$ \\
\hline \multirow[t]{2}{*}{7} & $1.83, \mathrm{~m}$ & $1.67, \mathrm{~m}$ & $1.54, \mathrm{~m}$ & \\
\hline & $1.46, \mathrm{~d}(9.2)$ & $1.46, \mathrm{dd}(3.6,1.8)$ & $1.22, \mathrm{~m}$ & \\
\hline \multirow[t]{2}{*}{8} & $1.80, \mathrm{~m}$ & $1.64, \mathrm{~m}$ & 1.91, br d (14.5) & \\
\hline & $1.46, \mathrm{~d}(9.2)$ & $1.50, \mathrm{~m}$ & $1.71, \operatorname{td}(14.5,5.0)$ & \\
\hline \multirow[t]{2}{*}{9} & 2.31, br d (4.4) & $2.24, \operatorname{td}(13.2,4.8)$ & & $2.26, \mathrm{~d}(13.8)$ \\
\hline & & & & $1.65, \mathrm{~d}(13.8)$ \\
\hline 10 & & & 2.90, br d (13.5) & \\
\hline 11 & $1.84, \mathrm{~m}$ & $1.81, \mathrm{~m}$ & & \\
\hline 12 & $0.92,3 \mathrm{H}, \mathrm{d}(6.8)$ & $0.92,3 \mathrm{H}, \mathrm{d}(6.6)$ & $1.66,3 \mathrm{H}, \mathrm{s}$ & \\
\hline 13 & $0.78,3 \mathrm{H}, \mathrm{d}(6.8)$ & $0.70,3 \mathrm{H}, \mathrm{d}(6.6)$ & $5.08,4.87$, both s & $1.84,3 \mathrm{H}, \mathrm{s}$ \\
\hline 14 & $0.84,3 \mathrm{H}, \mathrm{d}(6.8)$ & $0.90,3 \mathrm{H}, \mathrm{d}(6.6)$ & $2.05,3 \mathrm{H}, \mathrm{s}$ & $1.03,3 \mathrm{H}, \mathrm{s}$ \\
\hline \multirow[t]{2}{*}{15} & $3.49,2 \mathrm{H}, \mathrm{qd}(10.8,4.8)$ & $3.49, \mathrm{~d}(10.8)$ & $0.90, \mathrm{~d}(6.5)$ & $5.11, \mathrm{~s}$ \\
\hline & & $3.43, \mathrm{~d}(10.8)$ & & $4.77, \mathrm{~s}$ \\
\hline 9-OOH & & & 7.42, br s & \\
\hline
\end{tabular}

${ }^{1}$ Spectrum recorded at $400 \mathrm{MHz}$ in $\mathrm{CDCl}_{3} .{ }^{2}$ Spectrum recorded at $600 \mathrm{MHz}$ in $\mathrm{CDCl}_{3} .{ }^{3}$ Spectrum recorded at $500 \mathrm{MHz}_{\text {in } \mathrm{CDCl}_{3} .}^{4} \mathrm{~J}$ values are in $\mathrm{Hz}$.

The relative stereochemistry of $\mathbf{1 3}$ was examined mainly with the assistance of an NOE experiment. It was found that $\mathrm{H}_{3}-14\left(\delta_{\mathrm{H}} 0.84, \mathrm{~d}, J=6.8 \mathrm{~Hz}\right)$ showed an NOE correlation with one proton of $\mathrm{H}_{2}-2\left(\delta_{\mathrm{H}} 1.31, \mathrm{br} \mathrm{t}, J=10.8 \mathrm{~Hz}\right)$, which further correlated with $\mathrm{H}-4\left(\delta_{\mathrm{H}}\right.$ $1.63, \mathrm{~m})$; therefore, assuming the $\beta$-orientation of $\mathrm{H}_{3}-14$, the above methylene proton and $\mathrm{H}-4$ should also be positioned on the $\beta$ face, while $\mathrm{H}-1\left(\delta_{\mathrm{H}} 1.96, \mathrm{~m}\right)$, the other proton of $\mathrm{H}_{2}-2$ 
$\left(\delta_{\mathrm{H}} 1.82, \mathrm{~m}\right)$, and isopropyl group at C-4 were positioned on the $\alpha$ face. Furthermore, $\mathrm{H}-1$ exhibited NOE correlations with both $\mathrm{H}-2 \alpha$ and $\mathrm{H}-9\left(\delta_{\mathrm{H}} 2.31, \mathrm{br} \mathrm{d}, J=4.4 \mathrm{~Hz}\right)$, revealing the $\alpha$-orientation of H-9. Subsequently, $\mathrm{H}_{2}-15\left(\delta_{\mathrm{H}} 3.54\right.$ and 3.46, both $\left.\mathrm{dd}, J=8.4,4.8 \mathrm{~Hz}\right)$ showed an NOE correlation with one proton of $\mathrm{H}_{2}-7\left(\delta_{\mathrm{H}} 1.46, \mathrm{~d}, J=9.2 \mathrm{~Hz}\right)$, while the $\alpha$ oriented $\mathrm{H}-9$ which further correlated with another proton of $\mathrm{H}-7\left(\delta_{\mathrm{H}} 1.83, \mathrm{~m}\right)$, suggesting that the 6-hydroxymethyl group should be placed on the $\beta$ face, and in contrast, 6-hydroxy group should be positioned on the $\alpha$ face. Consequently, the relative configuration of $\mathbf{1 3}$ was elucidated as $1 S^{*}, 4 R^{*}, 6 S^{*}$, and $9 S^{*}$ (Figure 11).
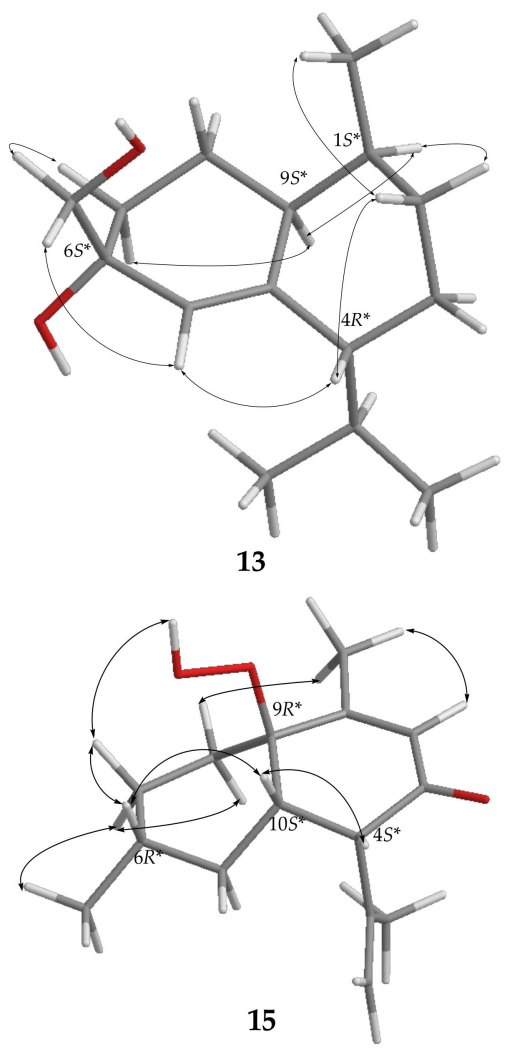

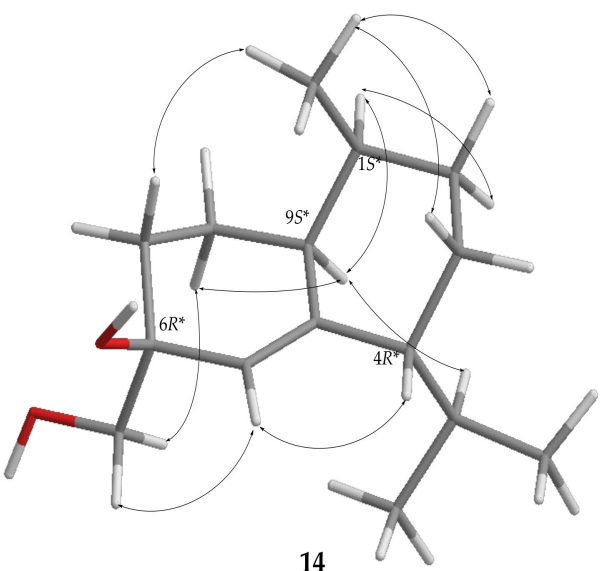

14

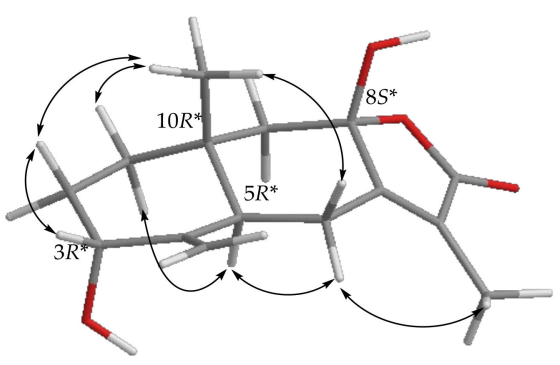

16

Figure 11. Selected NOE correlations of compounds 13-16.

The HRESIMS data of cespilin B (14) $\left(m / z 261.1824[\mathrm{M}+\mathrm{Na}]^{+}\right)$established a molecular formula of $\mathrm{C}_{15} \mathrm{H}_{26} \mathrm{O}_{2}$, the same as that of $\mathbf{1 3}$. Analysis of $2 \mathrm{D}$ NMR spectroscopic data, including $\mathrm{HSQC}, \mathrm{COSY}$, and $\mathrm{HMBC}$, revealed that $\mathbf{1 4}$ should possess the same molecular skeleton as that of $\mathbf{1 3}$ (Figure 5). Additionally, the NMR data (Tables 6 and 7) of $\mathbf{1 4}$ were highly similar in all aspects to those of $\mathbf{1 3}$, implying that $\mathbf{1 4}$ is a structurally similar isomer of 13. Comparison of the NOE correlations of both $\mathbf{1 3}$ and $\mathbf{1 4}$ revealed that both compounds possess the same $1 S^{*}, 4 \mathrm{R}^{*}$, and $9 \mathrm{~S}^{*}$ relative configurations. From the NOE correlations of the $\alpha$-oriented $\mathrm{H}-9\left(\delta_{\mathrm{H}} 2.24, \mathrm{td}, J=13.2,4.8 \mathrm{~Hz}\right)$ with $\mathrm{H}-8 \alpha\left(\delta_{\mathrm{H}} 1.64, \mathrm{~m}\right)$, as well as $\mathrm{H}_{2}-15$ $\left(\delta_{\mathrm{H}} 3.49\right.$ and 3.43 , both $\mathrm{d}, J=10.8 \mathrm{~Hz}$ ) further correlated with $\mathrm{H}-8 \alpha$, the 6-hydroxymethyl group should be placed on the $\alpha$ face, while the hydroxy group at C- 6 should be $\beta$-oriented. Compound 14 was thus found to be the C-6 epimer of 13 , and the relative configuration was assigned to be $1 S^{*}, 4 R^{*}, 6 R^{*}$, and $9 S^{*}$ (Figure 11).

Cespilin $\mathrm{C}(\mathbf{1 5})$ has the molecular formula $\mathrm{C}_{15} \mathrm{H}_{22} \mathrm{O}_{3}$ as shown by HRESIMS spectrum $\left(m / z 273.1464[\mathrm{M}+\mathrm{Na}]^{+}\right)$. The IR spectrum of $\mathbf{1 5}$ showed the absorption of an $\alpha, \beta-$ unsaturated ketone $\left(1683 \mathrm{~cm}^{-1}\right)$ which was further characterized from the corresponding ${ }^{13} \mathrm{C}$ NMR signals (Table 6) of $\delta_{\mathrm{C}} 197.7(\mathrm{C}), 162.7(\mathrm{C})$, and $128.6(\mathrm{CH})$. The NMR signals at $\delta_{\mathrm{C}} 84.0(\mathrm{C})$ and $\delta_{\mathrm{H}} 7.42(1 \mathrm{H}$, br s) revealed the presence of a hydroperoxy group at the $\mathrm{sp}^{3}$ nonprotonated carbon. Analysis of the COSY spectrum of $\mathbf{1 5}$ identified one proton 
sequence from $\mathrm{H}-4$ to $\mathrm{H}_{2}-8$ via $\mathrm{H}-10$, which assembled the major part of the planar structure of $\mathbf{1 5}$ with the crucial HMBC correlations as shown in Figure 5.

However, the connection of C-8/C-9 and C-9/C-10 could not be observed by COSY and $\mathrm{HMBC}$ correlations; instead, the two single bonds were established to fulfill the cadinane skeleton of $\mathbf{1 5}$ by the molecular formula and the tetrahedron nature of $\mathrm{sp}^{3}$ carbons. The relative structure of $\mathbf{1 5}$ was elucidated by the analysis of NOE correlations (Figure 11). Assuming the $\beta$-orientation of $\mathrm{H}-4\left(\delta_{\mathrm{H}} 3.26, \mathrm{~d}, J=13.5 \mathrm{~Hz}\right), \mathrm{NOE}$ correlations of $\mathrm{H}-4$ with $\mathrm{H}-10\left(\delta_{\mathrm{H}} 2.90\right.$, br d, $\left.J=13.5 \mathrm{~Hz}\right)$ and $\mathrm{H}-10$ with $\mathrm{H}-6\left(\delta_{\mathrm{H}} 1.61, \mathrm{~m}\right)$ implied the $\beta$-orientation of both $\mathrm{H}-6$ and $\mathrm{H}-10$, while the $\alpha$-orientation of the isopropenyl group at $\mathrm{C}-4$ and the methyl group $\left(\delta_{\mathrm{H}} 0.90, \mathrm{~d}, J=6.5 \mathrm{~Hz}\right)$ at C-6. Subsequently, one proton of $\mathrm{H}_{2}-7$ $\left(\delta_{\mathrm{H}} 1.54, \mathrm{~m}\right)$ displayed NOE correlations with both the hydroperoxy proton $\left(\delta_{\mathrm{H}} 7.42, \mathrm{~s}\right)$ and $\mathrm{H}-6$, while the other proton of $\mathrm{H}_{2}-7\left(\delta_{\mathrm{H}} 1.22, \mathrm{~m}\right)$ correlated with $\mathrm{H}_{3}-15$, reflecting that the 9 -hydroperoxy group should be situated on the $\beta$-face. Finally, the relative stereochemistry of 15 was thus established as $4 S^{*}, 6 R^{*}, 9 R^{*}$, and $10 S^{*}$.

Compound $\mathbf{1 6}$ was isolated as a white amorphous powder. The HRESIMS of $\mathbf{1 6}$ exhibited a sodiated pseudomolecular ion peak at $m / z 287.1255[\mathrm{M}+\mathrm{Na}]^{+}$and revealed a molecular formula of $\mathrm{C}_{15} \mathrm{H}_{20} \mathrm{O}_{4}$, implying six degrees of unsaturation. The IR absorptions displayed the presence of the hydroxy $\left(3418 \mathrm{~cm}^{-1}\right)$ and carbonyl $\left(1732 \mathrm{~cm}^{-1}\right)$ groups. A comparison of the NMR data (Tables 6 and 7) of $\mathbf{1 6}$ to those of a known metabolite atractylenolide III (25) [30-33], could well describe the molecular framework of $\mathbf{1 6}$ as eudesmane-type sesquiterpenoid. A difference was found that the methylene $\left(\mathrm{H}_{2}-3\right)$ of 25 was substituted with a hydroxy group in $\mathbf{1 6}$ (Figures 1 and 5).

The relative configuration of $\mathbf{1 6}$ was established by NOESY experiments and NMR spectroscopic data. $\mathrm{H}_{3}-14\left(\delta_{\mathrm{H}} 1.03, \mathrm{~s}\right)$ showed an NOE interaction with one proton of $\mathrm{H}_{2}-1$ $\left(\delta_{\mathrm{H}} 1.38, \mathrm{~m}\right)$, while $\mathrm{H}-5\left(\delta_{\mathrm{H}} 2.45, \mathrm{br} \mathrm{s}\right)$ displayed an NOE correlation with the other proton of $\mathrm{H}_{2}-1\left(\delta_{\mathrm{H}} 1.71, \mathrm{td}, J=13.8,4.2 \mathrm{~Hz}\right)$, therefore, $\mathrm{H}-5$ was suggested to be $\alpha$-oriented as $\mathrm{H}_{3}-14$ was well known $\beta$-oriented for the eudesmane-type sesquiterpenoids [15,32]. In addition, NOE correlations were observed for one proton of $\mathrm{H}_{2}-2\left(\delta_{\mathrm{H}} 1.87, \mathrm{dt}, J=14.4,3.6 \mathrm{~Hz}\right)$ with both $\mathrm{H}-3\left(\delta_{\mathrm{H}} 4.37, \mathrm{br} \mathrm{s}\right)$ and $\mathrm{H}_{3}-14$, could reflect the $\alpha$-orientation of the hydroxy group at C-3. Additionally, the ${ }^{13} \mathrm{C}$ NMR signals of C-7 $\left(\delta_{\mathrm{C}} 159.4, \mathrm{C}\right), \mathrm{C}-8\left(\delta_{\mathrm{C}} 103.1, \mathrm{C}\right)$, and C-9 $\left(\delta_{\mathrm{C}}\right.$ $\left.51.0, \mathrm{CH}_{2}\right)$ in 16 were found to be similar to those of atractylenolide III $(25)\left(\delta_{\mathrm{C}} 160.6, \mathrm{C}\right.$, C-7; $\left.103.2, \mathrm{C}, \mathrm{C}-8 ; 51.3, \mathrm{CH}_{2}, \mathrm{C}-9\right)$, while in 8-epi-atractylenolide III C-7 $\left(\delta_{\mathrm{C}} 157.7\right)$ and $\mathrm{C}-9$ $\left(\delta_{C} 47.7\right)$ were shifted upfield and C-8 $\left(\delta_{C} 109.1\right)$ was shifted downfield, suggesting that the hydroxy group at C-8 in $\mathbf{1 6}$ should be positioned on the $\beta$ face [33]. On the basis of the above analyses, and the other shown in Figure 11, the structure of $\mathbf{1 6}$ was thus elucidated to be $\left(3 R^{*}, 5 R^{*}, 8 S^{*}, 10 R^{*}\right)-3 \alpha, 8 \beta$-dihydroxy-eudesma-4(15),7(11)-dien-8,12-olide and named cespitulolide (16).

\subsection{Anti-Inflammatory Activities of the EtOAc Extract and the Isolated Compounds 1-28}

The anti-inflammatory activities of the EtOAc extract were screened in terms of the suppression of TNF- $\alpha$ production and NO release, as well as the inhibition of upregulation of pro-inflammatory iNOS and COX-2 gene, in LPS-induced DCs. The results of a preliminary study at a concentration of $100 \mu \mathrm{g} / \mathrm{mL}$ showed that the relative activities of this extract in inhibiting the production of TNF- $\alpha$ and NO were $84.1 \pm 4.2$ and $76.1 \pm 1.4 \%$, respectively, and it could reduce the levels of iNOS and COX-2 gene to $15.9 \pm 0.4$, and $28.6 \pm 4.1 \%$, respectively, too. For the discovery of bioactive compounds with anti-inflammatory abilities by inhibition of TNF- $\alpha$ and NO overproduction, 1-28 isolated from this extract were further assayed (Table 8). At a concentration of $100 \mu \mathrm{M}, 1-3$ could potently inhibit $95.0 \pm 0.2$, $95.7 \pm 0.4$, and $95.8 \pm 0.1 \%$ TNF- $\alpha$ production, respectively, relative to the control cells treated with LPS only. The respective $\mathrm{IC}_{50}$ values of $1-3,47.2,48.6$, and $41.1 \mu \mathrm{M}$, were further measured. Compounds 2, 12, 19, and 21 showed significant activities to inhibit NO releasing at $63.3 \pm 1.6,61.1 \pm 0.5,63.7 \pm 0.8$, and $61.7 \pm 1.0 \%$, respectively, at the same concentration. The $\mathrm{IC}_{50}$ values of 49.7, 51.9, and $57.4 \mu \mathrm{M}$, respectively, of $\mathbf{2}, \mathbf{1 9}$, and $2 \mathbf{2}$ in inhibiting the NO production were also measured. On the other hand, the anti-inflammatory 
potentials of compounds 1-28 in inhibition toward the accumulation of pro-inflammatory iNOS and COX-2 gene expression in the same LPS-induced DCs model were also evaluated (Figures 12 and 13, and Table 9). At a concentration of $25 \mu \mathrm{M}, 2$ was found to effectively reduce the gene expression of iNOS and COX-2 to $0.3 \pm 0.1$ and $2.9 \pm 0.6 \%$, respectively, relative to the control cells stimulated with LPS only. Meanwhile, 1, 13-15, 20, and 28 were found to conspicuously reduce the gene expression of iNOS to $3.6 \pm 1.8,7.4 \pm 2.9,1.5 \pm 0.8$, $4.6 \pm 2.9,0.2 \pm 0.1$, and $1.2 \pm 0.5 \%$, respectively, while $1,13,18$, and 22 could strongly reduce the COX-2 gene level to $4.2 \pm 0.1,4.4 \pm 3.5,4.5 \pm 0.5$, and $2.1 \pm 0.4 \%$, respectively, at a concentration of $100 \mu \mathrm{M}$. On the contrary, 6 significantly enhanced the gene expression of iNOS to $281.2 \pm 15.4 \%$, and 16 exhibited obvious activity of enhancing $196.9 \pm 55.1 \%$ COX-2 gene expression, at the same concentration of $100 \mu \mathrm{M}$.

Table 8. Inhibitory effects of compounds 1-28 on TNF- $\alpha$ expression and NO production in LPSinduced dendritic cells.

\begin{tabular}{|c|c|c|c|c|}
\hline \multirow{2}{*}{ No. } & \multirow{2}{*}{$\begin{array}{c}\text { TNF- } \alpha \text { Expression } \\
\text { Inh } \%^{1}\end{array}$} & & \multirow{2}{*}{$\begin{array}{c}\text { NO Production } \\
\text { Inh } \%\end{array}$} & \\
\hline & & & & \\
\hline S9-EA ${ }^{2}$ & $84.1 \pm 4.2$ & $* * * *$ & $76.1 \pm 1.4$ & $* * * *$ \\
\hline 1 & $95.0 \pm 0.2$ & $* * * *$ & $39.8 \pm 0.6$ & $* * * *$ \\
\hline 2 & $95.7 \pm 0.4$ & $* * * *$ & $63.3 \pm 1.6$ & $* * * *$ \\
\hline 3 & $95.8 \pm 0.1$ & $* * * *$ & $44.0 \pm 0.9$ & $* * * *$ \\
\hline 4 & $32.6 \pm 11.6$ & * & $51.1 \pm 0.1$ & $* * * *$ \\
\hline 5 & $39.5 \pm 7.8$ & $* *$ & $56.8 \pm 0.2$ & $* * * *$ \\
\hline 6 & $29.8 \pm 6.7$ & & $43.3 \pm 2.0$ & $* * * *$ \\
\hline 7 & $48.4 \pm 10.9$ & $* * *$ & $48.6 \pm 1.5$ & $* * * *$ \\
\hline 8 & $29.7 \pm 17.9$ & & $55.6 \pm 1.4$ & $* * * *$ \\
\hline 9 & $46.6 \pm 2.6$ & $* * *$ & $50.7 \pm 0.6$ & $* * * *$ \\
\hline 10 & $44.1 \pm 7.1$ & $* *$ & $46.7 \pm 0.6$ & $* * * *$ \\
\hline 11 & $34.3 \pm 1.7$ & $*$ & $50.8 \pm 0.6$ & $* * * *$ \\
\hline 12 & $44.4 \pm 2.7$ & $* *$ & $61.1 \pm 0.5$ & $* * * *$ \\
\hline 13 & $48.3 \pm 12.6$ & $* * *$ & $44.5 \pm 0.1$ & $* * * *$ \\
\hline 14 & $33.3 \pm 4.8$ & $*$ & $55.6 \pm 1.3$ & $* * * *$ \\
\hline 15 & $19.5 \pm 2.9$ & & $49.6 \pm 0.4$ & $* * * *$ \\
\hline 16 & $42.2 \pm 4.1$ & $* *$ & $41.9 \pm 1.5$ & $* * * *$ \\
\hline 17 & $36.1 \pm 0.6$ & $* * * *$ & $58.6 \pm 0.9$ & $* * * *$ \\
\hline 18 & $52.3 \pm 6.1$ & $* * * *$ & $58.5 \pm 1.1$ & $* * * *$ \\
\hline 19 & $46.3 \pm 4.4$ & $* * * *$ & $63.7 \pm 0.8$ & $* * * *$ \\
\hline 20 & $42.7 \pm 5.1$ & $* * * *$ & $56.3 \pm 0.6$ & $* * * *$ \\
\hline 21 & $41.9 \pm 3.2$ & $* * * *$ & $61.7 \pm 1.0$ & $* * * *$ \\
\hline 22 & $4.9 \pm 7.7$ & & $38.2 \pm 1.1$ & $* * * *$ \\
\hline 23 & $5.3 \pm 8.8$ & & $59.3 \pm 9.4$ & $* * * *$ \\
\hline 24 & $-0.6 \pm 2.0$ & & $30.4 \pm 2.9$ & $* * * *$ \\
\hline 25 & $-4.7 \pm 0.9$ & & $29.6 \pm 8.9$ & $* * * *$ \\
\hline 26 & $3.8 \pm 6.2$ & & $9.5 \pm 4.3$ & $* * * *$ \\
\hline 27 & $5.8 \pm 3.5$ & & $15.3 \pm 2.5$ & \\
\hline 28 & $-3.5 \pm 7.4$ & & $6.3 \pm 6.0$ & \\
\hline $\mathrm{DEX}^{3}$ & $85.6 \pm 3.4$ & $* * * *$ & $73.4 \pm 1.3$ & $* * * *$ \\
\hline
\end{tabular}

${ }^{1}$ Percentage of inhibition (Inh \%) at a concentration $100 \mu \mathrm{M}$ for 1-28 and $100 \mu \mathrm{g} / \mathrm{mL}$ for S9-EA compared with the control group (100\% for stimulated LPS alone). Results are presented as mean \pm SEM. $(n=3-4) .{ }^{*} p<0.05$, ${ }^{* *} p<0.01,{ }^{* * *} p<0.001,{ }^{* * * *} p<0.0001 .{ }^{2}$ S9 EA: the EtOAc extract of soft coral Cespitularia sp. ${ }^{3}$ Positive control: dexamethasone (DEX) at $100 \mu \mathrm{M}$. 
Table 9. Inhibitory effects of compounds 1-28 on iNOS and COX-2 mRNA expression in LPS-induced dendritic cells.

\begin{tabular}{|c|c|c|c|c|}
\hline \multirow{2}{*}{ No. } & \multirow{2}{*}{$\frac{\text { iNOS mRNA }}{\operatorname{Exp}^{1}{ }^{1}}$} & & \multirow{2}{*}{$\begin{array}{c}\text { COX-2 mRNA } \\
\text { Exp \% }\end{array}$} & \\
\hline & & & & \\
\hline S9-EA ${ }^{2}$ & $15.9 \pm 0.4$ & $* *$ & $28.6 \pm 4.1$ & $* *$ \\
\hline 1 & $3.6 \pm 1.8$ & $* * *$ & $4.2 \pm 0.1$ & $* * * *$ \\
\hline 2 & $0.3 \pm 0.1$ & $* * *$ & $2.9 \pm 0.6$ & $* * * *$ \\
\hline 3 & $64.6 \pm 1.8$ & & $25.6 \pm 12.7$ & $* *$ \\
\hline 4 & $67.4 \pm 11.6$ & & $21.8 \pm 1.1$ & $* *$ \\
\hline 5 & $71.0 \pm 10.2$ & & $43.1 \pm 25.8$ & \\
\hline 6 & $281.2 \pm 15.4$ & $* * * *$ & $65.4 \pm 3.1$ & \\
\hline 7 & $115.9 \pm 14.3$ & & $46.7 \pm 4.4$ & \\
\hline 8 & $29.0 \pm 1.7$ & $* *$ & $15.5 \pm 2.4$ & $* * *$ \\
\hline 9 & $35.2 \pm 10.1$ & $*$ & $47.9 \pm 1.8$ & \\
\hline 10 & $70.0 \pm 1.8$ & & $36.9 \pm 14.7$ & $*$ \\
\hline 11 & $36.0 \pm 5.8$ & * & $19.6 \pm 4.1$ & $* *$ \\
\hline 12 & $20.5 \pm 3.4$ & $* *$ & $11.2 \pm 1.7$ & $* * *$ \\
\hline 13 & $7.4 \pm 2.9$ & $* * *$ & $4.4 \pm 3.5$ & $* * *$ \\
\hline 14 & $1.5 \pm 0.8$ & $* * *$ & $43.4 \pm 26.2$ & \\
\hline 15 & $4.6 \pm 2.9$ & $* * *$ & $110.5 \pm 29.7$ & \\
\hline 16 & $18.4 \pm 4.4$ & $* *$ & $196.9 \pm 55.1$ & $* * * *$ \\
\hline 17 & $22.0 \pm 3.8$ & $* *$ & $11.9 \pm 3.7$ & $* * *$ \\
\hline 18 & $19.7 \pm 11.3$ & $* *$ & $4.5 \pm 0.5$ & $* * *$ \\
\hline 19 & $17.7 \pm 1.3$ & $* *$ & $27.6 \pm 1.9$ & $* *$ \\
\hline 20 & $0.2 \pm 0.1$ & $* * *$ & $14.8 \pm 6.1$ & $* * *$ \\
\hline 21 & $19.8 \pm 11.6$ & $* *$ & $43.8 \pm 7.9$ & \\
\hline 22 & $48.2 \pm 7.9$ & & $2.1 \pm 0.4$ & $* * * *$ \\
\hline 23 & $32.7 \pm 14.9$ & * & $35.4 \pm 18.0$ & $*$ \\
\hline 24 & $66.0 \pm 38.8$ & & $21.7 \pm 11.1$ & $* *$ \\
\hline 25 & $13.7 \pm 1.9$ & $* * *$ & $141.5 \pm 30.1$ & \\
\hline 26 & $15.0 \pm 4.1$ & $* *$ & $49.3 \pm 25.0$ & \\
\hline 27 & $25.4 \pm 12.6$ & $* *$ & $117.6 \pm 43.8$ & \\
\hline 28 & $1.2 \pm 0.5$ & $* * *$ & $81.8 \pm 42.4$ & \\
\hline $\mathrm{DEX}^{3}$ & $44.3 \pm 4.3$ & $*$ & $4.5 \pm 0.5$ & $* * *$ \\
\hline
\end{tabular}

${ }^{1}$ Percentage of expression (Exp \%) at a concentration $100 \mu \mathrm{M}$ (except for 2:25 $\mu \mathrm{M}, 3: 50 \mu \mathrm{M}$, and S9-EA: $100 \mu \mathrm{g} / \mathrm{mL}$ ) compared with the control group ( $100 \%$ for stimulated LPS alone). Results are presented as mean \pm SEM. $(n=3-4)$. ${ }^{*} p<0.05,{ }^{* *} p<0.01,{ }^{* * *} p<0.001,{ }^{* * * *} p<0.0001 .{ }^{2}$ S9 EA: the EtOAc extract of soft coral Cespitularia sp. ${ }^{3}$ Positive control: dexamethasone (DEX) at $100 \mu \mathrm{M}$.

iNOS

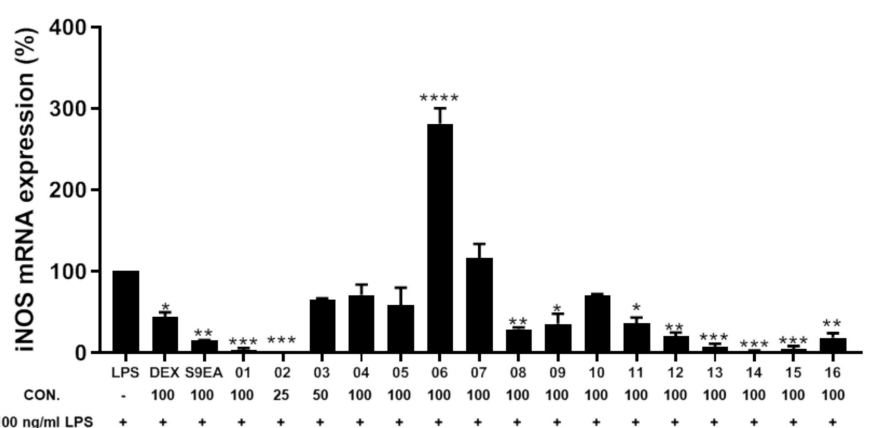

iNOS

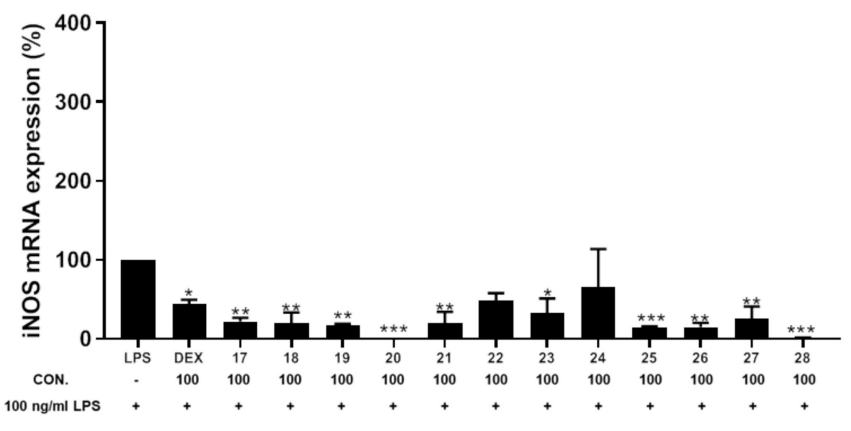

Figure 12. The inhibitory effect of 1-28 on LPS-induced iNOS mRNA expression in dendritic cells by the RT-PCR analysis. The values are mean SEM $(n=3) ;{ }^{*} p<0.05,{ }^{* *} p<0.01,{ }^{* * *} p<0.001,{ }^{* * * *} p<0.0001$ compared with the LPS alone stimulated group. The relative intensity of the LPS alone stimulated group was taken as $100 \%$. The bar chart shows the results of the EtOAc extract of soft coral Cespitularia sp. (S9-EA) at $100 \mu \mathrm{g} / \mathrm{mL}$ and compounds 1-28 (25-100 $\mu \mathrm{M})$ toward iNOS mRNA expression. 
coX-2

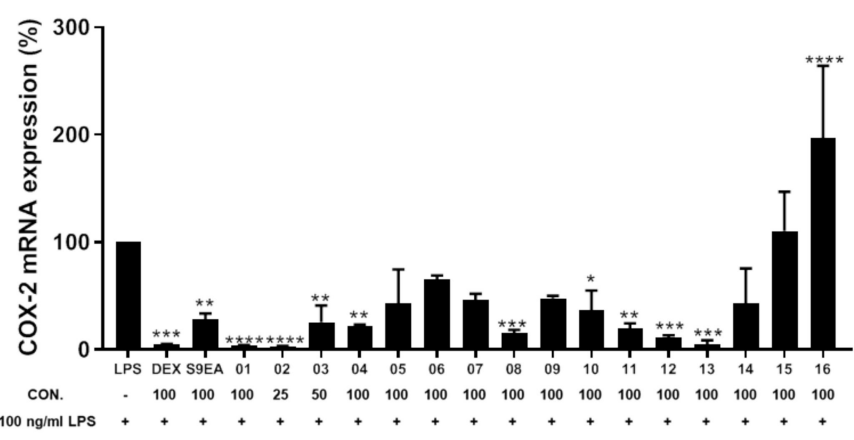

cox-2

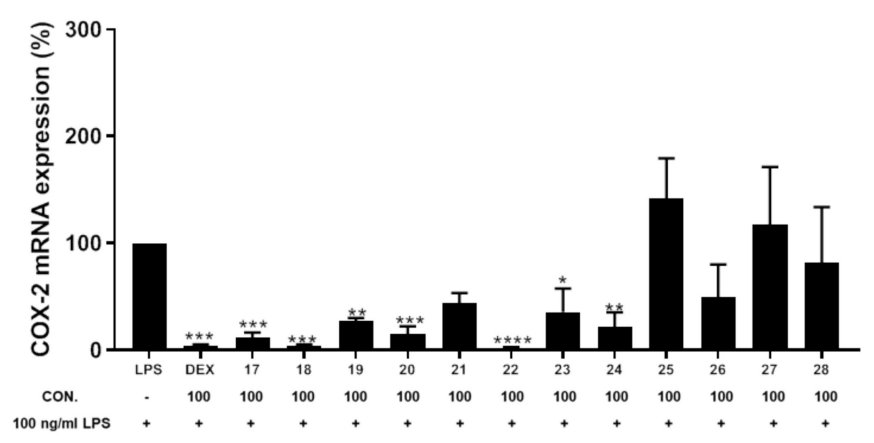

Figure 13. The inhibitory effect of 1-28 on LPS-induced COX-2 mRNA expression in dendritic cells by the RT-PCR analysis. The values are mean SEM $(n=3) ;^{*} p<0.05,{ }^{* *} p<0.01,{ }^{* * *} p<0.001,{ }^{* * * *} p<0.0001$ compared with the LPS alone stimulated group. The relative intensity of the LPS alone stimulated group was taken as $100 \%$. The bar chart shows the results of the EtOAc extract of soft coral Cespitularia sp. (S9-EA) at $100 \mu \mathrm{g} / \mathrm{mL}$ and compounds 1-28 (25-100 $\mu \mathrm{M})$ toward COX-2 mRNA expression.

\section{Discussion}

The pro-inflammatory cytokine TNF- $\alpha$, and reactive nitrogen species (RNS), such as $\mathrm{NO}$, are shown to involve in the physiological regulation of immune responses [39-41]. The inducible enzymes iNOS and COX-2 are also critical regulators of inflammation [40,42]. iNOS and COX-2 are also known to express together in inflamed responses and overproduction of NO can enhance the expression of COX-2 protein [43]. Generally, the inappropriate production of TNF- $\alpha$ and NO, as well as high iNOS and COX-2 protein and gene expression were found to be related to the pathogenesis of many inflammatory related diseases [44-51] such as AIDS, Alzheimer's, arthritis, cancer, diabetes, stroke, multiple sclerosis, obesity, and Parkinson's disease. Therefore, substances with inhibitory ability toward the overproduction of these inflammatory mediators are candidates for the development of new pharmaceutics in the treatment of chronic inflammation and autoimmune diseases $[52,53]$.

The anti-inflammatory potential of all isolated compounds revealed that compounds 1-3 and 12-15 might represent promising anti-inflammatory agents, in particular, $\mathbf{1}$ and $\mathbf{2}$ not only could significantly inhibit the production of TNF- $\alpha$ and NO but also displayed potent suppression to the expression of iNOS and COX-2 gene. Compound 13 might also be regarded as a promising inducible enzyme inhibitor as it can potently inhibit the expression of both iNOS and COX-2 genes.

From the structure-activity relationship (SAR), the tetracyclic verticillane-type diterpenes $\mathbf{1}$ and $\mathbf{2}$ were showing significant activities for each biological study relative to 3-8, owing to the presence of an acrylate group at C-20. Furthermore, 2 exhibited stronger anti-inflammatory abilities at lower concentrations $(25 \mu \mathrm{M})$ than $\mathbf{1}$ at higher concentrations $(100 \mu \mathrm{M})$. Thus, the acrylate group at C-20 and the hydroxy group at C-6 in epoxyfuranyl verticillane-type metabolites could effectively enhance the anti-inflammatory activity. The bicyclic verticillane-type norditerpene $\mathbf{1 2}$ displayed more effective anti-inflammatory activities than 11, suggesting that the presence of the $\alpha, \beta$-conjugated ketone at $C-13$ as in $\mathbf{1 2}$ could strengthen activities from the allylic hydroxy group at C-13 as in 11. On the other hand, the cadinane-type squiterpenes 13-15 exhibited significant inhibition toward iNOS gene expression, however, the presence of a hydroperoxy group and/or conjugated enone group as shown in $\mathbf{1 5}$ might promote the COX-2 gene expression.

\section{Materials and Methods}

\subsection{General Experimental Procedures}

Values of specific optical rotation were determined on a JASCO P-1020 digital polarimeter. UV spectra were recorded on a JASCO V-650 spectrophotometer. IR spectra were measured on a JASCO FT-IR-4100 and Nicolet iS5 FT-IR infrared spectrophotometers. ESIMS and HRESIMS data were obtained with a Bruker APEX II mass spectrometer. 
NMR spectra were recorded on a JEOL ECZ600R FT-NMR (or a Varian Unity INOVA 500 FT-NMR, or a Varian MR 400 FT-NMR) instrument at $600 \mathrm{MHz}$ (or $500 \mathrm{MHz}$, or $400 \mathrm{MHz}$ ) for ${ }^{1} \mathrm{H}$ and $150 \mathrm{MHz}$ (or $125 \mathrm{MHz}$, or $100 \mathrm{MHz}$ ) for ${ }^{13} \mathrm{C}$, respectively. All NMR experiments were measured using $\mathrm{CDCl}_{3}$ or benzene- $d_{6}$ as the solvent. Silica gel (Merck, 230-400 mesh) and Sephadex LH-20 (GE Healthcare, 25-100 $\mu \mathrm{m}$ ) were used for column chromatography. High-performance liquid chromatography (HPLC) was performed on a HiTachi L-7100 HPLC system apparatus with a Supelco C18 $(250 \mathrm{~mm} \times 21.2 \mathrm{~mm}, 5 \mu \mathrm{m})$ or Hibar 250-10 C18 $(250 \mathrm{~mm} \times 21.2 \mathrm{~mm}, 5 \mu \mathrm{m})$ column.

\subsection{Animal Material}

The soft coral Cespitularia sp. was collected by hand using SCUBA at Green Island, which is located off the southeastern coast of Taiwan, in June 2007, at a depth of 10-15 m, and was stored in a freezer until extraction. A voucher specimen was deposited in the Department of Marine Biotechnology, National Sun Yat-sen University, Kaohsiung, Taiwan.

\subsection{Extraction and Isolation}

The frozen specimens of Cespitularia sp. (87.20 g, dry weight) were sliced and exhaustively extracted with EtOAc $(5 \times 2 \mathrm{~L})$ for $24 \mathrm{~h}$. The solvent-free extract was obtained and further purified by reverse-phase HPLC to afford new compounds 1-16 (Figure 1) and known compounds 17-28 (Figure 2). The EtOAc extract (4.26 g) was subjected to silica gel open column chromatography (diameter: $8 \mathrm{~cm}$; height: $30 \mathrm{~cm}$ ) and eluted with a gradient of EtOAc in $n$-hexane (0-100\%, stepwise), to furnish 15 fractions, A1-A15. Fraction A7, eluting with $n$-hexane-EtOAc (1:1), was purified over silica gel in open column (diameter: $2.5 \mathrm{~cm}$; height: $50 \mathrm{~cm}$ ) using $n$-hexane-EtOAc (1:1) to afford five subfractions A7-1-A7-5. Subfractions A7-3, A7-4, and A7-5 were further purified by reversed-phase (RP) HPLC using $\mathrm{CH}_{3} \mathrm{CN}-\mathrm{H}_{2} \mathrm{O}(1: 1), \mathrm{CH}_{3} \mathrm{CN}-\mathrm{H}_{2} \mathrm{O}$ (1:1.5), and $\mathrm{MeOH}-\mathrm{H}_{2} \mathrm{O}$ (2:1), respectively, to afford $\mathbf{1}(1.5 \mathrm{mg}), \mathbf{1 5}(0.5 \mathrm{mg}), 25(30.1 \mathrm{mg})$, and $26(1.0 \mathrm{mg})$ from A7-3, $7(0.5 \mathrm{mg})$ and $19(1.5 \mathrm{mg})$ from A7-4, and $3(2.0 \mathrm{mg}), \mathbf{4}(0.6 \mathrm{mg})$, and $\mathbf{1 8}(1.3 \mathrm{mg})$ from A7-5. Fraction A-8, eluting with $n$-hexane-EtOAc (1:2), was separated by silica gel column (diameter: $2.5 \mathrm{~cm}$; height: $50 \mathrm{~cm}$ ) chromatography using $n$-hexane-EtOAc (1:2) to give subfractions A8-1-A8-7. RP-HPLC was further performed to purify subfraction A8-4, using $\mathrm{MeOH}-\mathrm{H}_{2} \mathrm{O}(1.5: 1)$ to afford 5 (1.4 mg) and $6(1.1 \mathrm{mg})$, and $\mathrm{MeOH}-\mathrm{H}_{2} \mathrm{O}(2: 1)$ to afford $2(2.2 \mathrm{mg}), 27(3.7 \mathrm{mg})$, and 28 $(1.0 \mathrm{mg})$. Subfraction A8-5 was further separated by RP-HPLC using $\mathrm{MeOH}-\mathrm{H}_{2} \mathrm{O}$ (1.5:1) to yield $10(0.6 \mathrm{mg}), \mathbf{1 2}(1.0 \mathrm{mg})$, and $\mathbf{1 7}(6.6 \mathrm{mg})$. Subfraction A8-6 was purified by RP-HPLC using $\mathrm{CH}_{3} \mathrm{CN}-\mathrm{H}_{2} \mathrm{O}$ (1:1.5) to afford 13 (1.2 mg), $14(0.9 \mathrm{mg})$, and 20 (1.1 mg). Fraction A-9, eluting with $n$-hexane-EtOAc (1:4), was rechromatographed over silica gel column (diameter: $2.5 \mathrm{~cm}$; height: $50 \mathrm{~cm}$ ) using $n$-hexane-EtOAc (1:2) as the mobile phase to give nine subfractions, A9-1-A9-9. Subfractions A9-4 and A9-5 were purified by RP-HPLC using $\mathrm{CH}_{3} \mathrm{CN}-\mathrm{H}_{2} \mathrm{O}$ (1:1.5) to afford $8(1.0 \mathrm{mg})$ and $21(1.4 \mathrm{mg})$, respectively. Subfraction A9-7 was further purified by RP-HPLC using $\mathrm{CH}_{3} \mathrm{CN}-\mathrm{H}_{2} \mathrm{O}$ (1.5:1) to afford $22(5.8 \mathrm{mg})$. Fraction A-10, eluting with $n$-hexane-EtOAc (1:8), was separated using sephadex LH-20 column (diameter: $3 \mathrm{~cm}$; height: $100 \mathrm{~cm}$ ) chromatography with $100 \%$ acetone to furnish seven subfractions (A10-1-A10-7). Subfraction A10-3 was purified by RP-HPLC $\left(\mathrm{CH}_{3} \mathrm{CN}-\mathrm{H}_{2} \mathrm{O}\right.$, 1:1.5) to afford $23(0.6 \mathrm{mg})$, and subfraction A10-5 was chromatographed using RP-HPLC $\left(\mathrm{CH}_{3} \mathrm{CN}-\mathrm{H}_{2} \mathrm{O}, 1: 2\right)$ to yield $\mathbf{9}(1.2 \mathrm{mg}), \mathbf{1 1}(1.1 \mathrm{mg}), \mathbf{1 6}(0.5 \mathrm{mg})$, and $24(1.7 \mathrm{mg})$.

Cespitulin $\mathrm{H}(\mathbf{1})$ : White amorphous powder; $[\alpha]_{\mathrm{D}}^{25}+162\left(c 0.43, \mathrm{CHCl}_{3}\right) ; \mathrm{UV}(\mathrm{MeOH}) \lambda_{\max }$ $(\log \varepsilon) 239$ (3.3) and 213 (3.4); IR(neat) $v_{\max } 3480,2925,1741,1685,1617,1456,1386$, and 1170 $\mathrm{cm}^{-1} ;{ }^{1} \mathrm{H}$ and ${ }^{13} \mathrm{C}$ NMR data, see Tables 1 and 2; ESIMS $\mathrm{m} / z$ 425; HRESIMS $\mathrm{m} / z 425.1932$ $[\mathrm{M}+\mathrm{Na}]^{+}$(calcd for $\mathrm{C}_{23} \mathrm{H}_{30} \mathrm{O}_{6} \mathrm{Na}, 425.1935$ ).

Cespitulin I (2): White amorphous powder; $[\alpha]_{\mathrm{D}}^{25}-91\left(c 0.63, \mathrm{CHCl}_{3}\right) ; \mathrm{UV}(\mathrm{MeOH}) \lambda_{\max }$ (log ع) 210 (3.4); IR(neat) $v_{\max } 3440,2925,1740,1715,1634,1455,1386$, and $1166 \mathrm{~cm}^{-1} ;{ }^{1} \mathrm{H}$ and ${ }^{13} \mathrm{C}$ NMR data, see Tables 1 and 2; ESIMS $\mathrm{m} / z$ 427; HRESIMS $\mathrm{m} / z$ 427.2089 [M + Na] $]^{+}$ (calcd for $\mathrm{C}_{23} \mathrm{H}_{32} \mathrm{O}_{6} \mathrm{Na}$, 427.2091). 
Cespitulin J (3): Colorless oil; $[\alpha]_{\mathrm{D}}^{25}+29$ ( $\left.0.57, \mathrm{CHCl}_{3}\right)$; IR(neat) $v_{\max } 3446,2923,2853,1758$, 1636, 1457, 1385, and $1164 \mathrm{~cm}^{-1} ;{ }^{1} \mathrm{H}$ and ${ }^{13} \mathrm{C}$ NMR data, see Tables 1 and 2; ESIMS $\mathrm{m} / z$ 611; HRESIMS $m / z 611.4282[\mathrm{M}+\mathrm{Na}]^{+}$(calcd for $\mathrm{C}_{36} \mathrm{H}_{60} \mathrm{O}_{6} \mathrm{Na}, 611.4282$ ).

Cespitulin K (4): Colorless oil; $[\alpha]_{\mathrm{D}}^{25}+38$ (c 0.17, $\left.\mathrm{CHCl}_{3}\right)$; IR(neat) $v_{\max } 3420,2924,2853$, 1748, 1636, 1457, 1386, and $1111 \mathrm{~cm}^{-1} ;{ }^{1} \mathrm{H}$ and ${ }^{13} \mathrm{C} \mathrm{NMR}$ data, see Tables 1 and 2; ESIMS $m / z$ 637; HRESIMS $m / z 637.4440[\mathrm{M}+\mathrm{Na}]^{+}$(calcd for $\mathrm{C}_{38} \mathrm{H}_{62} \mathrm{O}_{6} \mathrm{Na}, 637.4439$ ).

Cespitulin L (5): White amorphous powder; $[\alpha]_{\mathrm{D}}^{25}+35$ (c 0.40, $\mathrm{CHCl}_{3}$ ); IR(neat) $v_{\max } 3445$, 2920, 1683, 1652, 1455, 1385, and $1187 \mathrm{~cm}^{-1} ;{ }^{1} \mathrm{H}$ and ${ }^{13} \mathrm{C}$ NMR data, see Tables 1 and 2; ESIMS $m / z$ 365; HRESIMS $m / z$ 365.2315 $[\mathrm{M}+\mathrm{H}]^{+}\left(\right.$calcd for $\mathrm{C}_{21} \mathrm{H}_{33} \mathrm{O}_{5}, 365.2323$ ).

Cespitulin M (6): White amorphous powder; $[\alpha]_{\mathrm{D}}^{25}-23$ (c 0.31, $\left.\mathrm{CHCl}_{3}\right)$; IR(neat) $v_{\max } 3446$, 2917, 1683, 1652, 1456, 1386, and $1209 \mathrm{~cm}^{-1} ;{ }^{1} \mathrm{H}$ and ${ }^{13} \mathrm{C}$ NMR data, see Tables 1 and 3; ESIMS $m / z$ 387; HRESIMS $m / z$ 387.2142 [M + Na] ${ }^{+}$(calcd for $\mathrm{C}_{21} \mathrm{H}_{32} \mathrm{O}_{5} \mathrm{Na}$, 387.2142).

Cespitulin N (7): White amorphous powder; $[\alpha]_{\mathrm{D}}^{25}+102$ (c $\left.0.14, \mathrm{CHCl}_{3}\right)$; IR(neat) $v_{\max } 3446$, 2917, 1733, 1652, 1456, 1386, and $1239 \mathrm{~cm}^{-1} ;{ }^{1} \mathrm{H}$ and ${ }^{13} \mathrm{C}$ NMR data, see Tables 3 and 4; ESIMS m/z 399; HRESIMS m/z 399.2142 [M + Na] ${ }^{+}$(calcd for $\mathrm{C}_{22} \mathrm{H}_{32} \mathrm{O}_{5} \mathrm{Na}, 399.2142$ ).

Cespitulin O (8): Colorless oil; $[\alpha]_{\mathrm{D}}^{25}-63$ (c 0.29, $\left.\mathrm{CHCl}_{3}\right)$; IR(neat) $v_{\max } 3419,2922,1733$, 1652, 1456, 1386, and $1224 \mathrm{~cm}^{-1} ;{ }^{1} \mathrm{H}$ and ${ }^{13} \mathrm{C}$ NMR data, see Tables 3 and 4; ESIMS m/z 393; HRESIMS $m / z$ 393.2267 [M + H] $]^{+}$(calcd for $\mathrm{C}_{22} \mathrm{H}_{33} \mathrm{O}_{6}, 393.2272$ ).

Cespitulactam L (9): Colorless oil; $[\alpha]_{\mathrm{D}}^{25}-132\left(\right.$ c 0.34, $\left.\mathrm{CHCl}_{3}\right) ; \mathrm{UV}(\mathrm{MeOH}) \lambda_{\max }(\log \varepsilon) 221$ (3.4); IR(neat) $v_{\max } 3245,2919,1698,1647,1457,1387$, and $1204 \mathrm{~cm}^{-1} ;{ }^{1} \mathrm{H}$ and ${ }^{13} \mathrm{C}$ NMR data, see Tables 3 and 4; ESIMS $m / z$ 368; HRESIMS $m / z 368.2195[\mathrm{M}+\mathrm{Na}]^{+}$(calcd for $\mathrm{C}_{21} \mathrm{H}_{31} \mathrm{O}_{3} \mathrm{NNa}$, 368.2196).

Cespitulin P (10): Colorless oil; $[\alpha]_{\mathrm{D}}^{25}+68$ (c 0.17, $\left.\mathrm{CHCl}_{3}\right)$; IR(neat) $v_{\max } 3445,2917,1732$, 1715, 1651, 1455, 1385, and $1219 \mathrm{~cm}^{-1} ;{ }^{1} \mathrm{H}$ and ${ }^{13} \mathrm{C}$ NMR data, see Table 5; ESIMS m/z 375; HRESIMS m/z 375.2141 [M + Na] ${ }^{+}$(calcd for $\mathrm{C}_{20} \mathrm{H}_{32} \mathrm{O}_{5} \mathrm{Na}, 375.2142$ ).

Cespitulin Q (11): Colorless oil; $[\alpha]_{\mathrm{D}}^{25}+176\left(c\right.$ 0.31, $\left.\mathrm{CHCl}_{3}\right)$; UV (MeOH) $\lambda_{\max }(\log \varepsilon) 212$ (3.3); IR(neat) $v_{\max } 3418,2917,1699,1652,1456,1386$, and $1232 \mathrm{~cm}^{-1},{ }^{1} \mathrm{H}$ and ${ }^{13} \mathrm{C}$ NMR data, see Tables 3 and 4; ESIMS m/z 305; HRESIMS m/z 305.2108 [M + H] $]^{+}$(calcd for $\mathrm{C}_{19} \mathrm{H}_{29} \mathrm{O}_{3}$, 305.2111).

Cespitulin R (12): White amorphous powder; $[\alpha]_{\mathrm{D}}^{25}+46\left(c\right.$ 0.29, $\left.\mathrm{CHCl}_{3}\right)$; UV (MeOH) $\lambda_{\max }$ $(\log \varepsilon) 225$ (3.2); IR(neat) $v_{\max } 3420,2919,1748,1684,1653,1457,1387$, and $1223 \mathrm{~cm}^{-1} ;{ }^{1} \mathrm{H}$ and ${ }^{13} \mathrm{C}$ NMR data, see Tables 3 and 4; ESIMS $m / z$ 325; HRESIMS $m / z$ 325.1777 [M + Na] ${ }^{+}$ (calcd for $\mathrm{C}_{19} \mathrm{H}_{26} \mathrm{O}_{3} \mathrm{Na}, 325.1774$ ).

Cespilin A (13): Colorless oil; $[\alpha]_{\mathrm{D}}^{25}+56$ (c 0.34, $\left.\mathrm{CHCl}_{3}\right)$; IR(neat) $v_{\max } 3392,2926,2870$, 1652, 1456, 1380, and $1050 \mathrm{~cm}^{-1} ;{ }^{1} \mathrm{H}$ and ${ }^{13} \mathrm{C}$ NMR data, see Tables 6 and 7; ESIMS m/z 261; HRESIMS $m / z 261.1824[\mathrm{M}+\mathrm{Na}]^{+}$(calcd for $\mathrm{C}_{15} \mathrm{H}_{26} \mathrm{O}_{2} \mathrm{Na}, 261.1825$ ).

Cespilin B (14): Colorless oil; $[\alpha]_{\mathrm{D}}^{25}+60$ (c 0.26, $\mathrm{CHCl}_{3}$ ); IR(neat) $v_{\max } 3357,2925,2869,1652$, 1456, 1381, $1060 \mathrm{~cm}^{-1} ;{ }^{1} \mathrm{H}$ and ${ }^{13} \mathrm{C}$ NMR data, see Tables 6 and 7; ESIMS $\mathrm{m} / \mathrm{z} 261$; HRESIMS $m / z 261.1824[\mathrm{M}+\mathrm{Na}]^{+}$(calcd for $\mathrm{C}_{15} \mathrm{H}_{26} \mathrm{O}_{2} \mathrm{Na}, 261.1825$ ).

Cespilin C (15): Colorless oil; $[\alpha]_{\mathrm{D}}^{25}-39$ ( $c$ 0.14, $\left.\mathrm{CHCl}_{3}\right)$; UV (MeOH) $\lambda_{\max }(\log \varepsilon) 211$ (3.1); IR(neat) $v_{\max } 2924,2851,1683,1653,1456,1376$, and $1301 \mathrm{~cm}^{-1} ;{ }^{1} \mathrm{H}$ and ${ }^{13} \mathrm{C}$ NMR data, see Tables 6 and 7; ESIMS $m / z$ 273; HRESIMS $m / z 273.1464[\mathrm{M}+\mathrm{Na}]^{+}$(calcd for $\mathrm{C}_{15} \mathrm{H}_{22} \mathrm{O}_{3} \mathrm{Na}$, 273.1461).

Cespitulolide (16): White amorphous powder; $[\alpha]_{\mathrm{D}}^{25}+136\left(\right.$ c 0.14, $\left.\mathrm{CHCl}_{3}\right)$; UV (MeOH) $\lambda_{\max }$ $(\log \varepsilon) 213$ (3.2); IR(neat) $v_{\max } 3418,2917,1732,1651,1455,1385$, and $1217 \mathrm{~cm}^{-1} ;{ }^{1} \mathrm{H}$ and ${ }^{13} \mathrm{C}$ NMR data, see Tables 6 and 7; ESIMS $m / z$ 287; HRESIMS $m / z 287.1255$ [M + Na] ${ }^{+}$(calcd for $\mathrm{C}_{15} \mathrm{H}_{20} \mathrm{O}_{4} \mathrm{Na}$, 287.1254). 


\subsection{In Vitro Anti-Inflammatory Assay}

\subsubsection{Measurement of Cytokine Production by Dendritic Cells (DCs)}

The experiment for measuring cytokine was tested by enzyme-link immunosorbent assay (ELISA) from the previously reported method [6,7]. The DCs were manipulated with lipopolysaccharide (LPS, $100 \mathrm{ng} / \mathrm{mL}$ ) from Escherichia coli 055:B5, and the following treatment with the isolated compounds for $24 \mathrm{~h}$. The optical density of the production of TNF- $\alpha$ was measured at $450 \mathrm{~nm}$ using the ELISA reader.

\subsubsection{Measurement of Nitric Oxide (NO) Production by DCs}

DC cells were seeded in 24-well plates at a density of $1 \times 10^{6} / \mathrm{mL}$. DCs were treated with each compound for $1 \mathrm{~h}$ and then stimulated with $100 \mathrm{ng} / \mathrm{mL}$ LPS for $24 \mathrm{~h}$. The nitrite concentration in the medium was measured as an indicator of NO production through the Griess reaction. Briefly, $100 \mu \mathrm{L}$ of cell culture supernatant was reacted with $100 \mu \mathrm{L}$ of Griess reagent (1:1 mixture of $2 \%$ sulfanilamide and $0.2 \% N$-(1-naphthyl-)ethylenediamine dihydrochloride in water) in 96-well plate at room temperature for $10 \mathrm{~min}$, and absorbance at $540 \mathrm{~nm}$ was recorded using sandwich ELISA assays [6,7].

4.4.3. Measurement of Pro-Inflammatory Inducible NO Synthase (iNOS) and Cyclooxygenase-2 (COX-2) Gene Expression by DCs

The suppression activities of compounds were measured by the examining suppression of LPS-induced upregulation of pro-inflammatory iNOS and COX-2 gene expression in DCs using real-time polymerase chain reaction (PCR) [14]. Briefly, DCs $\left(1 \times 10^{6} / \mathrm{mL}\right)$ were incubated in 6-well plates and treated with each compound for $1 \mathrm{~h}$, and then were added the LPS (100 ng/mL), stimulating for $24 \mathrm{~h}$. Subsequently, cells were harvested and isolated total RNA using Trizol reagent. A total of $2 \mu \mathrm{g}$ RNA was reverse-transcribed using M-MLV Reverse Transcriptase to synthesize cDNA (Applied Biosystems). Gene expression levels of iNOS and COX-2 were analyzed using SYBR-Green PCR Master Mix with StepOne PCR System (Applied Biosystems; Thermo Fisher Scientific). Relative gene expression levels were calculated using the $2^{-\Delta \Delta C t}$ method and normalized to GAPDH; all the primers which were used are listed in Table 10 [54].

Table 10. Primers of quantitative RT-PCR.

\begin{tabular}{|c|c|c|}
\hline Gene & Reverse Primer & Forward Primer \\
\hline iNOS & 5'-CCAATGTTTCCCTGACTTTCCCA-3' & 5'-CAGAGGGGTAGGCTTGTCTC-3' \\
\hline COX-2 & 5'-CAGGAGGATGGAGTTGTTGTAG-3' & 5'-ACCAGCAGTTCCAGTATCAGA-3' \\
\hline GAPDH & 5'-TGTCATCATACTTGGCAGGTTTCT-3' & 5'-CGTGTTCCTACCCCCAATGT-3' \\
\hline
\end{tabular}

\subsection{Statistical Analysis}

The results are expressed as the mean \pm SEM, and comparisons were made using one-way ANOVA by Tukey's post hoc test (Graphpad Prism 5.0, GraphPad Software, San Diego, CA, USA). A probability value of 0.05 or less was considered significant. The software Sigma Plot was used for the statistical analysis.

\section{Conclusions}

In conclusion, our chemical investigation demonstrated that the soft coral Cespitularia sp. could be a good source of bioactive substances. Eight new tricyclic verticillane-type diterpenes 1-9, one novel norditerpene 10, two new dicyclic verticillane-type norditerpenes 11 and 12, three cadinane-type sesquiterpenes 13-15, and one eudesmane-type sesquiterpenoid 16, along with twelve known metabolites 17-28, were isolated from this investigation. The structural framework of verticillane-type derivatives was found to be close to the tricyclic taxane skeleton [55] and obtained from marine organisms only in the soft coral genus Cespitularia [15]. Furthermore, the cadinane-type sesquiterpenes 13-15 were isolated from the soft coral genus Cespitularia for the first time. From the results of the 
evaluated biological activities, it appears that compounds 1, 2, and 13 might be promising compounds for further marine anti-inflammatory drug development.

Supplementary Materials: The following are available online at https:/ / www.mdpi.com/article/ 10.3390/ph14121252/s1, Figure S1: HRESIMS spectrum of 1, Figure S2: ${ }^{1} \mathrm{H}$ NMR spectrum of 1 in $\mathrm{C}_{6} \mathrm{D}_{6}$ at $500 \mathrm{MHz}$, Figure S3: ${ }^{13} \mathrm{C}$ NMR spectrum of 1 in $\mathrm{C}_{6} \mathrm{D}_{6}$ at $125 \mathrm{MHz}$, Figure S4: HSQC spectrum of 1 in $\mathrm{C}_{6} \mathrm{D}_{6}$, Figure S5: COSY spectrum of 1 in $\mathrm{C}_{6} \mathrm{D}_{6}$, Figure S6: HMBC spectrum of 1 in $\mathrm{C}_{6} \mathrm{D}_{6}$, Figure S7: NOESY spectrum of 1 in $\mathrm{C}_{6} \mathrm{D}_{6}$, Figure S8: HRESIMS spectrum of 2, Figure S9: ${ }^{1} \mathrm{H}$ NMR spectrum of 2 in $\mathrm{CDCl}_{3}$ at $400 \mathrm{MHz}$, Figure S10: ${ }^{13} \mathrm{C} \mathrm{NMR}$ spectrum of 2 in $\mathrm{CDCl}_{3}$ at $100 \mathrm{MHz}$, Figure S11: HSQC spectrum of 2 in $\mathrm{CDCl}_{3}$, Figure S12: COSY spectrum of 2 in $\mathrm{CDCl}_{3}$, Figure S13: HMBC spectrum of $\mathbf{2}$ in $\mathrm{CDCl}_{3}$, Figure S14: NOESY spectrum of $\mathbf{2}$ in $\mathrm{CDCl}_{3}$, Figure S15: HRESIMS spectrum of 3, Figure S16: ${ }^{1} \mathrm{H}$ NMR spectrum of 3 in $\mathrm{CDCl}_{3}$ at $500 \mathrm{MHz}$, Figure S17: ${ }^{13} \mathrm{C}$ NMR spectrum of 3 in $\mathrm{CDCl}_{3}$ at $125 \mathrm{MHz}$, Figure S18: HSQC spectrum of 3 in $\mathrm{CDCl}_{3}$, Figure S19: COSY spectrum of 3 in $\mathrm{CDCl}_{3}$, Figure S20: HMBC spectrum of 3 in $\mathrm{CDCl}_{3}$, Figure S21: NOESY spectrum of 3 in $\mathrm{CDCl}_{3}$, Figure S22: HRESIMS spectrum of 4, Figure S23: ${ }^{1} \mathrm{H}$ NMR spectrum of 4 in $\mathrm{CDCl}_{3}$ at $500 \mathrm{MHz}$, Figure S24: ${ }^{13} \mathrm{C}$ NMR spectrum of 4 in $\mathrm{CDCl}_{3}$ at $125 \mathrm{MHz}$, Figure S25: HSQC spectrum of 4 in $\mathrm{CDCl}_{3}$, Figure S26: COSY spectrum of 4 in $\mathrm{CDCl}_{3}$, Figure S27: $\mathrm{HMBC}$ spectrum of 4 in $\mathrm{CDCl}_{3}$, Figure S28: NOESY spectrum of 4 in $\mathrm{CDCl}_{3}$, Figure S29: HRESIMS spectrum of 5, Figure S30: ${ }^{1} \mathrm{H}$ NMR spectrum of 5 in $\mathrm{CDCl}_{3}$ at $500 \mathrm{MHz}$, Figure S31: ${ }^{13} \mathrm{C}$ NMR spectrum of 5 in $\mathrm{CDCl}_{3}$ at $125 \mathrm{MHz}$, Figure S32: HSQC spectrum of 5 in $\mathrm{CDCl}_{3}$, Figure S33: COSY spectrum of 5 in $\mathrm{CDCl}_{3}$, Figure S34: HMBC spectrum of 5 in $\mathrm{CDCl}_{3}$, Figure S35: NOESY spectrum of 5 in $\mathrm{CDCl}_{3}$, Figure S36: HRESIMS spectrum of 6, Figure S37: ${ }^{1} \mathrm{H}$ NMR spectrum of $6 \mathrm{CDCl}_{3}$ at $500 \mathrm{MHz}$, Figure S38: ${ }^{13} \mathrm{C} \mathrm{NMR} \mathrm{spectrum}$ of 6 in $\mathrm{CDCl}_{3}$ at $125 \mathrm{MHz}$, Figure S39: HSQC spectrum of 6 in $\mathrm{CDCl}_{3}$, Figure S40: COSY spectrum of 6 in $\mathrm{CDCl}_{3}$, Figure S41: HMBC spectrum of 6 in $\mathrm{CDCl}_{3}$, Figure S42: NOESY spectrum of 6 in $\mathrm{CDCl}_{3}$, Figure S43: HRESIMS spectrum of 7, Figure S44: ${ }^{1} \mathrm{H}$ NMR spectrum of 7 in $\mathrm{CDCl}_{3}$ at $500 \mathrm{MHz}$, Figure S45: ${ }^{13} \mathrm{C}$ NMR spectrum of 7 in $\mathrm{CDCl}_{3}$ at $125 \mathrm{MHz}$, Figure S46: HSQC spectrum of 7 in $\mathrm{CDCl}_{3}$, Figure S47: COSY spectrum of 7 in $\mathrm{CDCl}_{3}$, Figure S48: $\mathrm{HMBC}$ spectrum of 7 in $\mathrm{CDCl}_{3}$, Figure S49: NOESY spectrum of 7 in $\mathrm{CDCl}_{3}$, Figure S50: HRESIMS spectrum of 8, Figure S51: ${ }^{1} \mathrm{H}$ NMR spectrum of 8 in $\mathrm{CDCl}_{3}$ at $500 \mathrm{MHz}$, Figure S52: ${ }^{13} \mathrm{C} \mathrm{NMR}$ spectrum of 8 in $\mathrm{CDCl}_{3}$ at $125 \mathrm{MHz}$, Figure S53: HSQC spectrum of 8 in $\mathrm{CDCl}_{3}$, Figure S54: COSY spectrum of 8 in $\mathrm{CDCl}_{3}$, Figure S55: HMBC spectrum of 8 in $\mathrm{CDCl}_{3}$, Figure S56: NOESY spectrum of 8 in $\mathrm{CDCl}_{3}$, Figure S57: HRESIMS spectrum of 9, Figure S58: ${ }^{1} \mathrm{H}$ NMR spectrum of 9 in $\mathrm{CDCl}_{3}$ at $500 \mathrm{MHz}$, Figure S59: ${ }^{13} \mathrm{C}$ NMR spectrum of 9 in $\mathrm{CDCl}_{3}$ at $125 \mathrm{MHz}$, Figure S60: HSQC spectrum of 9 in $\mathrm{CDCl}_{3}$, Figure S61: COSY spectrum of 9 in $\mathrm{CDCl}_{3}$, Figure S62: HMBC spectrum of 9 in $\mathrm{CDCl}_{3}$, Figure S63: NOESY spectrum of 9 in $\mathrm{CDCl}_{3}$, Figure S64: HRESIMS spectrum of 10, Figure S65: ${ }^{1} \mathrm{H}$ NMR spectrum of 10 in $\mathrm{CDCl}_{3}$ at $500 \mathrm{MHz}$, Figure S66: ${ }^{13} \mathrm{C}$ NMR spectrum of 10 in $\mathrm{CDCl}_{3}$ at $125 \mathrm{MHz}$, Figure S67: HSQC spectrum of 10 in $\mathrm{CDCl}_{3}$, Figure S68: COSY spectrum of 10 in $\mathrm{CDCl}_{3}$, Figure S69: $\mathrm{HMBC}$ spectrum of 10 in $\mathrm{CDCl}_{3}$, Figure S70: NOESY spectrum of $\mathbf{1 0}$ in $\mathrm{CDCl}_{3}$, Figure S71: HRESIMS spectrum of 11, Figure S72: ${ }^{1} \mathrm{H}$ NMR spectrum of 11 in $\mathrm{CDCl}_{3}$ at $500 \mathrm{MHz}$, Figure S73: ${ }^{13} \mathrm{C} \mathrm{NMR}$ spectrum of 11 in $\mathrm{CDCl}_{3}$ at $125 \mathrm{MHz}$, Figure S74: HSQC spectrum of $\mathbf{1 1}$ in $\mathrm{CDCl}_{3}$, Figure S75: COSY spectrum of $\mathbf{1 1}$ in $\mathrm{CDCl}_{3}$, Figure S76: HMBC spectrum of $\mathbf{1 1}$ in $\mathrm{CDCl}_{3}$, Figure S77: NOESY spectrum of $\mathbf{1 1}$ in $\mathrm{CDCl}_{3}$, Figure S78: HRESIMS spectrum of 12, Figure S79: ${ }^{1} \mathrm{H}$ NMR spectrum of 12 in $\mathrm{CDCl}_{3}$ at $500 \mathrm{MHz}$, Figure S80: ${ }^{13} \mathrm{C}$ NMR spectrum of 12 in $\mathrm{CDCl}_{3}$ at $125 \mathrm{MHz}$, Figure S81: HSQC spectrum of $\mathbf{1 2}$ in $\mathrm{CDCl}_{3}$, Figure S82: COSY spectrum of 12 in $\mathrm{CDCl}_{3}$, Figure S83: HMBC spectrum of 12 in $\mathrm{CDCl}_{3}$, Figure S84: NOESY spectrum of 12 in $\mathrm{CDCl}_{3}$, Figure S85: HRESIMS spectrum of 13, Figure S86: ${ }^{1} \mathrm{H}$ NMR spectrum of 13 in $\mathrm{CDCl}_{3}$ at $400 \mathrm{MHz}$, Figure S87: ${ }^{13} \mathrm{C}$ NMR spectrum of 13 in $\mathrm{CDCl}_{3}$ at $100 \mathrm{MHz}$, Figure S88: HSQC spectrum of 13 in $\mathrm{CDCl}_{3}$, Figure S89: COSY spectrum of 13 in $\mathrm{CDCl}_{3}$, Figure S90: HMBC spectrum of 13 in $\mathrm{CDCl}_{3}$, Figure S91: NOESY spectrum of 13 in $\mathrm{CDCl}_{3}$, Figure S92: HRESIMS spectrum of 14, Figure S93: ${ }^{1} \mathrm{H}$ NMR spectrum of 14 in $\mathrm{CDCl}_{3}$ at $600 \mathrm{MHz}$, Figure S94: ${ }^{13} \mathrm{C}$ NMR spectrum of 14 in $\mathrm{CDCl}_{3}$ at $150 \mathrm{MHz}$, Figure S95: HSQC spectrum of 14 in $\mathrm{CDCl}_{3}$, Figure S96: COSY spectrum of 14 in $\mathrm{CDCl}_{3}$, Figure S97: HMBC spectrum of 14 in $\mathrm{CDCl}_{3}$, Figure S98: NOESY spectrum of 14 in $\mathrm{CDCl}_{3}$, Figure S99: HRESIMS spectrum of 15, Figure S100: ${ }^{1} \mathrm{H}$ NMR spectrum of 15 in $\mathrm{CDCl}_{3}$ at $500 \mathrm{MHz}$, Figure S101: ${ }^{13} \mathrm{C}$ NMR spectrum of 15 in $\mathrm{CDCl}_{3}$ at $125 \mathrm{MHz}$, Figure S102: HSQC spectrum of 15 in $\mathrm{CDCl}_{3}$, Figure S103: COSY spectrum of 15 in $\mathrm{CDCl}_{3}$, Figure S104: HMBC spectrum of 15 in $\mathrm{CDCl}_{3}$, Figure S105: NOESY spectrum of 15 in $\mathrm{CDCl}_{3}$, Figure S106: HRESIMS spectrum of 16, Figure S107: ${ }^{1} \mathrm{H}$ NMR spectrum of 16 in $\mathrm{CDCl}_{3}$ at $600 \mathrm{MHz}$, Figure S108: ${ }^{13} \mathrm{C}$ NMR spectrum of 16 in $\mathrm{CDCl}_{3}$ at $150 \mathrm{MHz}$, Figure S109: HSQC spectrum of 16 in $\mathrm{CDCl}_{3}$, Figure S110: COSY spectrum 
of 16 in $\mathrm{CDCl}_{3}$, Figure S111: HMBC spectrum of 16 in $\mathrm{CDCl}_{3}$, Figure S112: NOESY spectrum of 16 in $\mathrm{CDCl}_{3}$, Figure S113: MMFF lowest energy conformers for 1, Figure S114: MMFF lowest energy conformers for 2, Table S1: ${ }^{1} \mathrm{H}$ and ${ }^{13} \mathrm{C}$ NMR spectroscopic data of compounds $\mathbf{1 7}$ and 18, Table S2: Energy analysis for MMFF conformational searching of compounds $\mathbf{1}$ and $\mathbf{2}$.

Author Contributions: J.-H.S. designed and guided the whole experiment. C.-C.L. and Y.-C.C. evaluated the anti-inflammatory activity. Y.-C.L. and C.-W.F. isolated the compounds and performed structure elucidation. J.-H.S. and Y.-C.L. carried out manuscript preparation. All authors have read and agreed to the published version of the manuscript.

Funding: This work was supported by grants from the Ministry of Science and Technology, Taiwan (MOST 107-2320-B-110-001-MY3 and 108-2320-B-110-003-MY2).

Institutional Review Board Statement: Not applicable.

Informed Consent Statement: Not applicable.

Data Availability Statement: Data is contained within the article and Supplementary Material.

Acknowledgments: The authors thank the assistance of the Instrumentation Center at National Sun Yat-sen University (MOST 110-2731-M-110-001) for measurement of NMR and MS data, and the technical assistance of Yu-Chi Lin on conformational searching.

Conflicts of Interest: The authors declare no conflict of interest.

\section{References}

1. Parameswaran, N.; Patial, S. Tumor Necrosis Factor- $\alpha$ Signaling in Macrophages. Crit. Rev. Eukaryot. Gene Expr. 2010, 20, 87-103. [CrossRef]

2. Tang, T.; Scambler, T.E.; Smallie, T.; Cunliffe, H.E.; Ross, E.A.; Rosner, D.R.; O’Neil, J.D.; Clark, A.R. Macrophage responses to lipopolysaccharide are modulated by a feedback loop involving prostaglandin E2, dual specificity phosphatase 1 and tristetraprolin. Sci. Rep. 2017, 7, 4350. [CrossRef]

3. $\quad$ Ling-Chien, H.; Wang, W.-H.; Chen, S.-H.; Chang, Y.-W.; Hung, L.-C.; Chen, C.-Y.; Chen, Y.-H. Lipopolysaccharide-Induced Nitric Oxide, Prostaglandin E2, and Cytokine Production of Mouse and Human Macrophages Are Suppressed by Pheophytin-b. Int. J. Mol. Sci. 2017, 18, 2637. [CrossRef]

4. Wei, W.-C.; Su, Y.-H.; Chen, S.-S.; Sheu, J.-H.; Yang, N.-S. GM-CSF plays a key role in zymosan-stimulated human dendritic cells for activation of Th1 and Th17 cells. Cytokine 2011, 55, 79-89. [CrossRef] [PubMed]

5. Si, C.; Zhang, R.; Wu, T.; Lu, G.; Hu, Y.; Zhang, H.; Xu, F.; Wei, P.; Chen, K.; Tang, H.; et al. Dendritic cell-derived nitric oxide inhibits the differentiation of effector dendritic cells. Oncotarget 2016, 7, 74834-74845. [CrossRef]

6. Lin, M.K.; Yu, Y.L.; Chen, K.C.; Chang, W.T.; Lee, M.S.; Yang, M.J.; Cheng, H.C.; Liu, C.H.; Chen, D.C.; Chu, C.L. Kaempferol from Semen cuscutae Attenuates the Immune Function of Dendritic Cells. Immunobiology 2011, 216, 1103-1109. [CrossRef] [PubMed]

7. Lai, K.-H.; You, W.-J.; Lin, C.-C.; El-Shazly, M.; Liao, Z.-J.; Su, J.-H. Anti-Inflammatory Cembranoids from the Soft Coral Lobophytum crassum. Mar. Drugs 2017, 15, 327. [CrossRef]

8. Ahmed, A.F.; Chen, Y.-W.; Huang, C.-Y.; Tseng, Y.-J.; Lin, C.-C.; Dai, C.-F.; Wu, Y.-C.; Sheu, J.-H. Isolation and Structure Elucidation of Cembranoids from a Dongsha Atoll Soft Coral Sarcophyton stellatum. Mar. Drugs 2018, 16, 210. [CrossRef] [PubMed]

9. Huang, C.-Y.; Sung, P.-J.; Uvarani, C.; Su, J.-H.; Lu, M.-C.; Hwang, T.-L.; Dai, C.-F.; Wu, S.-L.; Sheu, J.-H. Glaucumolides A and B, Biscembranoids with New Structural Type from a Cultured Soft Coral Sarcophyton glaucum. Sci. Rep. 2015, 5, 15624. [CrossRef] [PubMed]

10. Li, J.; Zhang, H.B.; Hung, W.L.; Qian, H.; Li, Y. TNF- $\alpha$ Inhibitors with Anti-Oxidative Stress Activity from Natural Products. Curr. Top. Med. Chem. 2012, 12, 1408-1421. [CrossRef]

11. Azab, A.; Nassar, A.; Azab, A.N. Anti-Inflammatory Activity of Natural Products. Molecules 2016, 21, 1321. [CrossRef]

12. Kiemer, A.K.; Hartung, T.; Huber, C.; Vollmar, A.M. Phyllanthus amarus has Anti-Inflammatory Potential by Inhibition of iNOS, COX-2, and Cytokines via the NF-kB Pathway. J. Hepatol. 2003, 38, 289-297. [CrossRef]

13. Kim, D.H.; Li, H.; Han, Y.E.; Jeong, J.H.; Lee, H.J.; Ryu, J.-H. Modulation of Inducible Nitric Oxide Synthase Expression in LPSStimulated BV-2 Microglia by Prenylated Chalcones from Cullen corylifolium (L.) Medik. through Inhibition of I-kB $\alpha$ Degradation. Molecules 2018, 23, 109. [CrossRef]

14. Chen, Y.C.; Yang, L.L.; Lee, T.J.F. Oroxylin A Inhibition of Lipopolysaccharide-Induced iNOS and COX-2 Gene Expression via Suppression of Nuclear Factor-kB Activation. Biochem. Pharmacol. 2000, 59, 1445-1457. [CrossRef]

15. Elshamy, A.I.; Nassar, M.I.; Mohamed, T.A.; Hegazy, M.-E.F. Chemical and biological profile of Cespitularia species: A mini review. J. Adv. Res. 2016, 7, 209-224. [CrossRef] [PubMed]

16. Shen, Y.-C.; Lo, K.-L.; Kuo, Y.-H.; Kuo, Y.-C.; Chen, C.-H.; Khalil, A.T. Cespihypotins Q-V, Verticillene Diterpenoids from Cespitularia hypotentaculata. J. Nat. Prod. 2008, 71, 1993-1997. [CrossRef] 
17. Duh, C.-Y.; El-Gamal, A.A.H.; Wang, S.-K.; Dai, C.-F. Novel Terpenoids from the Formosan Soft Coral Cespitularia hypotentaculata. J. Nat. Prod. 2002, 65, 1429-1433. [CrossRef]

18. Duh, C.-Y.; Li, C.-H.; Wang, S.-K.; Dai, C.-F. Diterpenoids, Norditerpenoids, and Secosteroids from the Formosan Soft Coral Cespitularia hypotentaculata. J. Nat. Prod. 2006, 69, 1188-1192. [CrossRef] [PubMed]

19. Lin, Y.-C.; Wang, S.-S.; Chen, C.-H.; Kuo, Y.-H.; Shen, Y.-C. Cespitulones A and B, Cytotoxic Diterpenoids of a New Structure Class from the Soft Coral Cespitularia taeniata. Mar. Drugs 2014, 12, 3477-3486. [CrossRef]

20. Shen, Y.-C.; Ho, C.-J.; Kuo, Y.-H.; Lin, Y.-S. Cespitulactones A and B, new diterpenoids from Cespitularia taeniata. Bioorganic Med. Chem. Lett. 2006, 16, 2369-2372. [CrossRef] [PubMed]

21. Shen, Y.-C.; Lin, Y.-S.; Kuo, Y.-H.; Cheng, Y.-B. Cespitulactams A, B, and C, three new nitrogen-containing diterpenes from Cespitularia taeniata May. Tetrahedron Lett. 2005, 46, 7893-7897. [CrossRef]

22. Shen, Y.-C.; Cheng, Y.-B.; Kobayashi, J.; Kubota, T.; Takahashi, Y.; Mikami, Y.; Ito, J.; Lin, Y.-S. Nitrogen-Containing Verticillene Diterpenoids from the Taiwanese Soft Coral Cespitularia taeniata. J. Nat. Prod. 2007, 70, 1961-1965. [CrossRef] [PubMed]

23. Roy, P.K.; Maarisit, W.; Roy, M.C.; Taira, J.; Ueda, K. Five New Diterpenoids from an Okinawan Soft Coral, Cespitularia sp. Mar. Drugs 2012, 10, 2741-2748. [CrossRef]

24. Cheng, Y.-B.; Chen, C.-Y.; Kuo, Y.-H.; Shen, Y.-C. New Nitrogen-Containing Sesquiterpenoids from the Taiwanese Soft Coral Cespitularia taeniata May. Chem. Biodivers. 2009, 6, 1266-1272. [CrossRef]

25. Roy, P.K.; Roy, M.C.; Taira, J.; Ueda, K. Structure and bioactivity of a trisnorditerpenoid and a diterpenoid from an Okinawan soft coral, Cespitularia sp. Tetrahedron Lett. 2014, 55, 1421-1423. [CrossRef]

26. Cheng, S.-Y.; Lin, E.-H.; Wen, Z.-H.; Chiang, M.Y.-N.; Duh, C.-Y. Two New Verticillane-Type Diterpenoids from the Formosan Soft Coral Cespitularia hypotentaculata. Chem. Pharm. Bull. 2010, 58, 848-851. [CrossRef] [PubMed]

27. Chang, J.-Y.; Fazary, A.; Lin, Y.-C.; Hwang, T.-L.; Shen, Y.-C. New Verticillane Diterpenoids from Cespitularia taeniata. Chem. Biodivers. 2012, 9, 654-661. [CrossRef]

28. Shen, Y.-C.; Wu, Y.-R.; Lin, J.-J.; Lo, K.-L.; Kuo, Y.-C.; Khalil, A.T. Eight new diterpenoids from soft coral Cespitularia hypotentaculata. Tetrahedron 2007, 63, 10914-10920. [CrossRef]

29. Shen, Y.-C.; Lin, J.-J.; Wu, Y.-R.; Chang, J.-Y.; Duh, C.-Y.; Lo, K.L. New norditerpenoids from Cespitularia hypotentaculata. Tetrahedron Lett. 2006, 47, 6651-6655. [CrossRef]

30. Duan, J.-A.; Wang, L.; Qian, S.; Su, S.; Tang, Y. A new cytotoxic prenylated dihydrobenzofuran derivative and other chemical constituents from the rhizomes of Atractylodes lancea DC. Arch. Pharmacal Res. 2008, 31, 965-969. [CrossRef] [PubMed]

31. Bohlmann, F.; Dutta, L.N.; Knauf, W.; Robinson, H.; King, R.M. Neue sesquiterpenlactone aus Aster umbellatus. Phytochemistry 1980, 19, 433-436. [CrossRef]

32. Hoang, L.S.; Tran, M.H.; Lee, J.-S.; Ngo, Q.M.T.; Woo, M.H.; Min, B.S. Inflammatory Inhibitory Activity of Sesquiterpenoids from Atractylodes macrocephala Rhizomes. Chem. Pharm. Bull. 2016, 64, 507-511. [CrossRef]

33. Li, Y.; Yang, X.-W. New eudesmane-type sesquiterpenoids from the processed rhizomes of Atractylodes macrocephala. J. Asian Nat. Prod. Res. 2014, 16, 123-128. [CrossRef] [PubMed]

34. Chen, L.; Izumi, S.; Ito, D.I.; Iwaeda, T.; Utsumi, R.; Hirata, T. Secretion of Allelochemicals from the Cultured Suspension Cells of Marchantia polymorpha. Chem. Lett. 1996, 3, 205-206. [CrossRef]

35. Halgren, T.A.; Nachbar, R.B. Merck molecular force field. IV. conformational energies and geometries for MMFF94. J. Comput. Chem. 1996, 17, 587-615. [CrossRef]

36. Lainer, J.; Dawid, C.; Dunkel, A.; Gläser, P.; Wittl, S.; Hofmann, T. Characterization of Bitter-Tasting Oxylipins in Poppy Seeds (Papaver somniferum L.). J. Agric. Food Chem. 2020, 68, 10361-10373. [CrossRef] [PubMed]

37. Chen, C.-T.; Munot, Y.S. Direct Atom-Efficient Esterification between Carboxylic Acids and Alcohols Catalyzed by Amphoteric, Water-Tolerant TiO(acac)2. J. Org. Chem. 2005, 70, 8625-8627. [CrossRef]

38. Leuenberger, M.G.; Engeloch-Jarret, C.; Woggon, W.D. The Reaction Mechanism of the Enzyme-Catalyzed Cleavage of $\beta$-Carotene to Retinal. Angew. Chem. Int. Ed. 2001, 40, 2613-2617. [CrossRef]

39. Jang, D.-I.; Lee, A.-H.; Shin, H.-Y.; Song, H.-R.; Park, J.-H.; Kang, T.-B.; Lee, S.-R.; Yang, S.-H. The Role of Tumor Necrosis Factor Alpha (TNF- $\alpha$ ) in Autoimmune Disease and Current TNF- $\alpha$ Inhibitors in Therapeutics. Int. J. Mol. Sci. 2021, 22, 2719. [CrossRef] [PubMed]

40. Kurach, Ł.; Kulczycka-Mamona, S.; Kowalczyk, J.; Skalicka-Woźniak, K.; Boguszewska-Czubara, A.; El Sayed, N.; Osmani, M.; Iwaniak, K.; Budzyńska, B. Mechanisms of the Procognitive Effects of Xanthotoxin and Umbelliferone on LPS-Induced Amnesia in Mice. Int. J. Mol. Sci. 2021, 22, 1779. [CrossRef]

41. Król, M.; Kepinska, M. Human Nitric Oxide Synthase-Its Functions, Polymorphisms, and Inhibitors in the Context of Inflammation, Diabetes and Cardiovascular Diseases. Int. J. Mol. Sci. 2020, 22, 56. [CrossRef] [PubMed]

42. Lin, C.-Y.; Kao, S.-H.; Hung, L.-C.; Chien, H.-J.; Wang, W.-H.; Chang, Y.-W.; Chen, Y.-H. Lipopolysaccharide-Induced Nitric Oxide and Prostaglandin E2 Production Is Inhibited by Tellimagrandin II in Mouse and Human Macrophages. Life 2021, 11, 411. [CrossRef] [PubMed]

43. Needleman, P.; Manning, P. Interactions between the inducible cyclooxygenase (COX-2) and nitric oxide synthase (iNOS) pathways: Implications for therapeutic intervention in osteoarthritis. Osteoarthr. Cartil. 1999, 7, 367-370. [CrossRef] [PubMed]

44. Zhao, Y.; Joshi-Barve, S.; Barve, S.; Chen, L.H. Eicosapentaenoic Acid Prevents LPS-Induced TNF- $\alpha$ Expression by Preventing NF-kB Activation. J. Am. Coll. Nutr. 2004, 23, 71-78. [CrossRef] 
45. Singh, V.K.; Mehrotra, S.; Narayan, P.; Pandey, C.M.; Agarwal, S.S. Modulation of Autoimmune Diseases by Nitric Oxide. Immunol. Res. 2000, 22, 1-19. [CrossRef]

46. Sonar, S.A.; Lal, G. The iNOS Activity During an Immune Response Controls the CNS Pathology in Experimental Autoimmune Encephalomyelitis. Front. Immunol. 2019, 10, 710. [CrossRef] [PubMed]

47. Chatzantoni, K.; Mouzaki, A. Anti-TNF- $\alpha$ Antibody Therapies in Autoimmune Diseases. Curr. Top. Med. Chem. 2006, 6, 1707-1714. [CrossRef] [PubMed]

48. Ferrer, M.D.; Busquets-Cortés, C.; Capó, X.; Tejada, S.; Tur, J.A.; Pons, A.; Sureda, A. Cyclooxygenase-2 Inhibitors as a Therapeutic Target in Inflammatory Diseases. Curr. Med. Chem. 2019, 26, 3225-3241. [CrossRef] [PubMed]

49. Kröncke, K.D.; Fehsel, K.; Kolb-Bachofen, V. Inducible nitric oxide synthase in human diseases. Clin. Exp. Immunol. 1998, 113, 147-156. [CrossRef]

50. Minghetti, L. Cyclooxygenase-2 (COX-2) in Inflammatory and Degenerative Brain Diseases. J. Neuropathol. Exp. Neurol. 2004, 63, 901-910. [CrossRef] [PubMed]

51. Hori, M.; Kita, M.; Torihashi, S.; Miyamoto, S.; Won, K.-J.; Sato, K.; Ozaki, H.; Karaki, H. Upregulation of iNOS by COX-2 in muscularis resident macrophage of rat intestine stimulated with LPS. Am. J. Physiol. Gastrointest. Liver Physiol. 2001, 280, G930-G938. [CrossRef] [PubMed]

52. Johnston, B.L.; Conly, J.M. Tumour Necrosis Factor Inhibitors and Infection: What is there to Know for Infectious Diseases Physicians? Can. J. Infect. Dis. Med. Microbiol. 2006, 17, 209-212. [CrossRef] [PubMed]

53. Smallwood, M.J.; Nissim, A.; Knight, A.R.; Whiteman, M.; Haigh, R.; Winyard, P.G. Oxidative stress in autoimmune rheumatic diseases. Free. Radic. Biol. Med. 2018, 125, 3-14. [CrossRef]

54. Liou, C.-J.; Lai, Y.-R.; Chen, Y.-L.; Chang, Y.-H.; Li, Z.-Y.; Huang, W.-C. Matrine Attenuates COX-2 and ICAM-1 Expressions in Human Lung Epithelial Cells and Prevents Acute Lung Injury in LPS-Induced Mice. Mediat. Inflamm. 2016, 2016, 3630485. [CrossRef] [PubMed]

55. Wang, Y.-F.; Su, X.-H.; Li, L.-G.; Wang, W.; Zhang, M.-L.; Huo, C.-H.; Shi, Q.-W. Verticillane Derivatives from Natural Sources. Chem. Biodivers. 2009, 6, 1661-1673. [CrossRef] 